PNL-7662

UC-602

\title{
An Evaluation of the Chemical, Radiological, and Ecological Conditions of West Lake on the Hanford Site
}

T. M. Poston

K. L. Price

D. R. Newcomer

March 1991

Prepared for the U.S. Department of Energy under Contract DE-AC06-76RLO 1830

Pacific Northwest Laboratory Operated for the U.S. Department of Energy by Battelle Memorial Institute 


\title{
DISCLAIMER
}

This report was prepared as an account of work sponsored by an agency of the United States Government. Neither the United States Government nor any agency thereof, nor Battelle Memorial Institute, nor any of their employees, makes any warranty, expressedor implied, or assumes any legal liability or responsibility for theaccuracy, completeness, or usefulnessof any information, apparatus, product, or processdisclosed, or represents that its use would not infringe privately owned rights. Referenceherein to any specific commercialproduct, process, or service by trade name, trademark, manufacturer, or otherwise does not necessarily constitute or imply its endorsement, recommendation, or favoring by the United States Government or any agency thereof, or Battelle Memorial Institute. The views and opinions of authors expressed herein do not necessarily state or reflect those of the United States Government or any agency thereof.

\author{
PACIFIC NORTHWEST LABORATORY \\ operatedby \\ BATTELLE MEMORIAL INSTITUTE \\ for the \\ UNITED STATES DEPARTMENT OF ENERGY \\ under Contract DE-ACO6-76RLO 1830
}

Printed in the United States of America

Available to DOE and DOE contractors from the

Office of Scientific and Technical Information, P.O. Box 62, Oak Ridge, TN 37831; prices available from (615) 576-8401. FTS 626-8401.

Available to the public from the National Technical Information Service, U.S. Department of Commerce, 5285 Port Royal Rd., Springfield, VA 22161. 
AN EVALUATION OF THE CHEMICAL, RADIOLOGICAL, AND ECOLOGICAL CONDITIONS OF WEST LAKE ON THE HANFORD SITE
T. M. Poston
K. L. Price
D. R. Newcomer

March 1991

Prepared for the U.S. Department of Energy under Contract DE-AC06-76RLO 1830

Pacific Northwest Laboratory

Richland, Washington 99352 


\section{SUMARY}

West Lake and its immediate surrounding basin represent a unique habitat that is dominated by highly saline water and soil. The basin offers a valuable research site for studies of a rare and complex wetland area in the desert. This report is an evaluation of the chemical, radiological, and ecological conditions at West Lake and describes how ground water influences site properties. The scope of this evaluation consisted of a sampling program in 1989 and a review of data from the perspective of assessing the impact of Hanford Site operations on the physical, chemical, and ecological conditions of West Lake and its surrounding basin.

The water level in West Lake fluctuates in relation to changes in the water table. These changes are influenced by aquifer recharge from past and present discharges of water to the ground in the 200 Areas. The connection between West Lake and ground water is also supported by the presence of ${ }^{3} \mathrm{H}$ and ${ }^{99} \mathrm{Tc}$ in the ground water and in the lake.

There are relatively high concentrations of uranium in West Lake; the highest concentrations are found in the northernmost isolated pool. Analyses of water, sediment, vegetation, and soil indicate possible shifts of isotopic ratios that indicate a reduction of ${ }^{235} \mathrm{U}$. Uranium-236 was not detected in West Lake water,; its presence would indicate neutron-activated ${ }^{235} \mathrm{U}$ from fuel reprocessing at Hanford.

Trace metals are found at elevated concentrations in West Lake. Arsenic, chromium, copper, and zinc were found at levels in excess of U.S. Environmental Protection Agency water quality criteria. It is not known if the presence of trace metals is normal for this highly saline lake or if past human sources contributed to the current level of metals in the lake. There was no indication of contamination by organic compounds, herbicides, or pesticides in West Lake water.

Levels of radiological and chemical contamination in the West Lake basin are relatively low. Concentrations of fission isotopes exceed those that could be explained by atmospheric fallout, but fall short of action levels for active waste management areas. 


\section{CONTENTS}

SUMMARY

INTRODUCTION. . . . . . . . . . . . . . . . . . . 1

HYDROGEOLOGY. . . . . . . . . . . . . . . . . . 7

GROUND-WATER CHEMISTRY ................... 9

AQUATICECOLOGY ........................... 12

Physical Characterization . . . . . . . . . . . 12

Water Chemistry ................. 12

Nutrient Balance ................ 15

Productivity ................... 15

Fauna ..................... 16

TERRESTRIAL ECOLOGY .................. 16

METHODS ............................ 17

GROUND WATER ..................... 17

WEST LAKE BASIN. . . . . . . . . . . . . . . . 20

SAMPLE ANALYSES. . . . . . . . . . . . . . . . 20

Radiological Analyses .............. . 20

Chemical Analyses................ 23

SAMPLING RESULTS. . . . . . . . . . . . . . . . . . 25

GROUND WATER ..................... 25

LAKE WATER ....................... 26

SEDIMENT . . . . . . . . . . . . . . . . . . 28

SALTDEPOSITS. . . . . . . . . . . . . . . . 29

SOIL ............................ 29

VEGETATION ........................... 30 


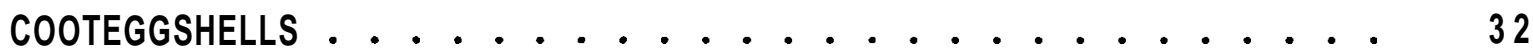

NONRADIOLOGICAL ANALYSES .............. 32

Groundwater ....................... 32

West Lake Surface Water ............. 36

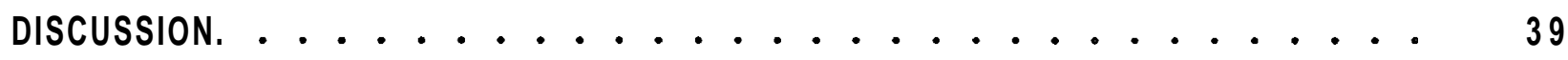

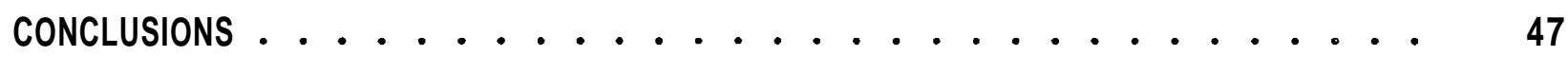

REFERENCES. . . . . . . . . . . . . . . . . . . 49

APPENDIX A - CONCENTRATIONS OF RADIONUCLIDES IN ENVIRONMENTAL MEDIA COLLECTED FROM THE WEST LAKE BASIN ........ A.I

APPENDIX B - ORGANIC CONTAMINANTS IN WEST LAKE WATER . . . . . . B. 1

APPENDIX C - HISTORICAL LEVELS OF CONTAMINANTS IN WEST LAKE AND GROUND WATER ........... C.1 


\section{INTRODUCTION}

West Lake is a highly saline and alkaline pond in a depression in the terrain southwest of Gable Mountain on the Hanford Site (Figure 1). Currently, West Lake consists of the main pond and three separate, smaller pools located to the immediate north (see Figure 1). The white areas along the shoreline consist of accumulated salt deposits. In the foreground lie the three smaller pools. Depending on water level, these smaller pools may have been connected; however, the growth of three-spined bulrush, Scirpus amerlcana, the tojograghy, and tos filling in of sediment in these areas have apparently isolat. d th. pools.

Aerial photogrsohs taken bstween 1964 and 1989 give some indication of the wat. $r$-level fluc? uations snd seditentation that have occurred over the ysars (Figure 2). As ricorded by aerial photography, the extensive exposed areas of white salt and alkali deposits show the pond at its lower level in 1979. In contrast, water levels in 1964 appear to represent a high-water mark for Wsst Lare.

Historically, West Lake was an intermittent natural pond that appeared in response to a rise in the water-table elevation as a result of seasonal fluctuations (Strait and Moore 1982). Jenkins (1922) referred to West Lake as a spring, reported to have been flowing when the Columbia River was high and to have been dry when the Columbia River was low. It is not clear at the present time if West Lake (a.k.a. West Pond, Honey Hill Pond) was present in 1945 when operations began in the 200 Areas. Records for 1945-1946 indicate that a "Spring 13" was sampled just north of "Honey Hill" for environmental monitoring purposes, but descriptions of the location of Spring 13 are unclear. Moreover, the location of Honey $\mathrm{Hill}$ has not been confirmed, except that it was described as being near Highway $4 \mathrm{~N}$ at Mile Post 3 . The term Honey Hill apparently refers to the location of a disposal site for sanitary sewage sludge from early Hanford construction camps. Documentation of the sludge disposal practice has not been located to date. Sampling at Spring 13 began in June 1945 and ended in July 1946. It is possible that Spring 13 was an incipient West Lake prior to the disposal of large quantities of water 


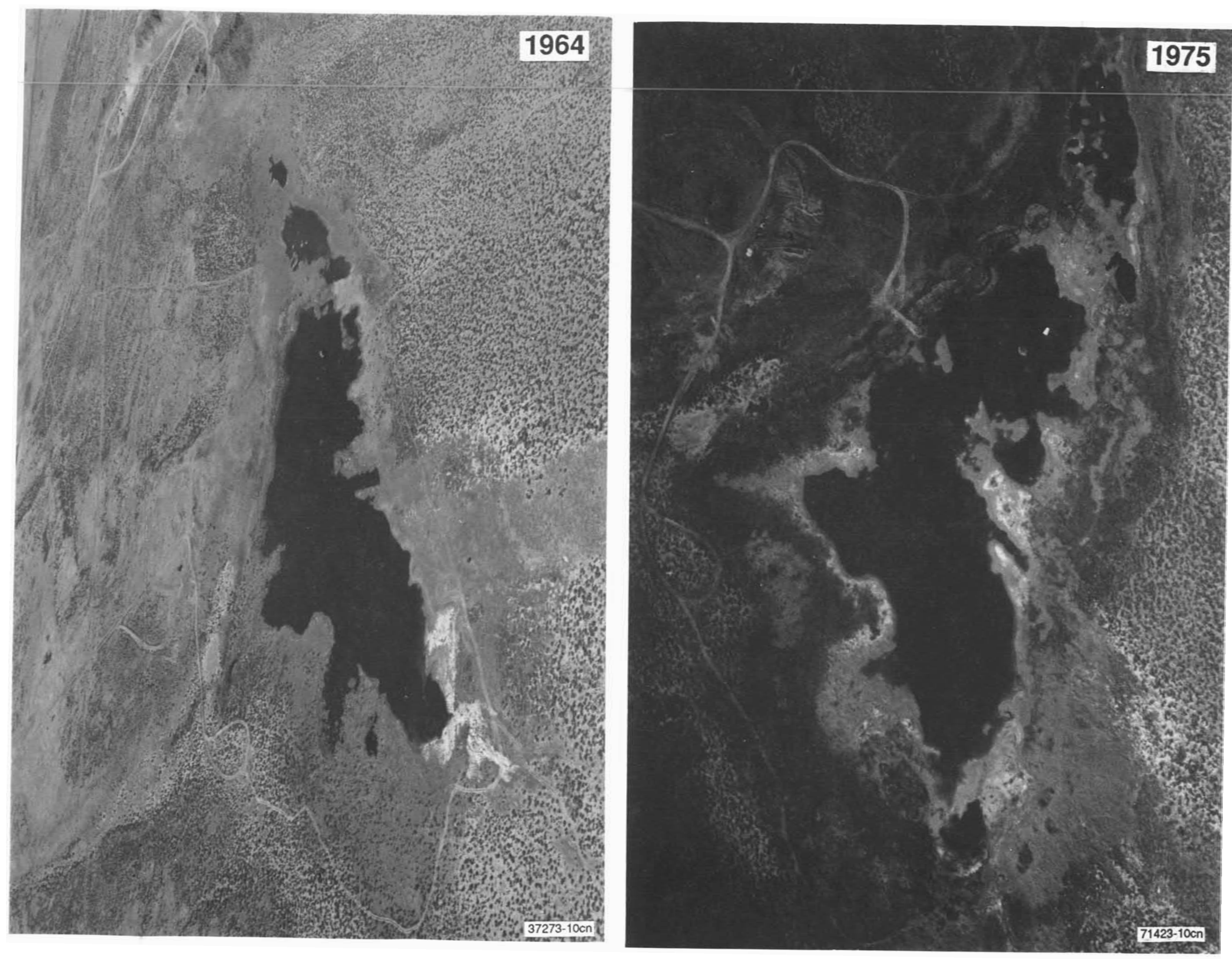

FIGURE 2 Aerial Photographs of West Lake Taken in $1964 \quad 1975$ 1979, and 1989 


\section{INTRODUCTION}

West Lake is a highly saline and alkaline pond in a depression in the terrain southwest of Gable Mountain on the Hanford Site (Figure 1). Currently, West Lake consists of the main pond and three separate, smaller pools located to the immediate north (see Figure 1). The white areas along the shoreline consist of accumulated salt deposits. In the foreground lie the three smaller pools. Depending on water level, these smaller pools may have been connected; however, the growth of three-spined bulrush, Scirpus americana, the topography, and the filling in of sediment in these areas have apparently isolated the pools.

Aerial photographs taken between 1964 and 1989 give some indication of the water-level fluctuations and sedimentation that have occurred over the years (Figure 2). As recorded by aerial photography, the extensive exposed areas of white salt and alkali deposits show the pond at its lower level in 1979. In contrast, water levels in 1964 appear to represent a high-water mark for'West Lake.

Historically, West Lake was an intermittent natural pond that appeared in response to a rise in the water-table elevation as a result of seasonal fluctuations (Strait and Moore 1982). Jenkins (1922) referred to West Lake as a spring, reported to have been flowing when the Columbia River was high and to have been dry when the Columbia River was low. It is not clear at the present time if West Lake (a.k.a. West Pond, Honey Hill Pond) was present in 1945 when operations began in the 200 Areas. Records for 1945-1946 indicate that a "Spring 13" was sampled just north of "Honey Hill" for environmental monitoring purposes, but descriptions of the location of Spring 13 are unclear. Moreover, the location of Honey Hill has not been confirmed, except that it was described as being near Highway $4 \mathrm{~N}$ at' Mile Post 3 . The term Honey Hill apparently refers to the location of a disposal site for sanitary sewage sludge from early Hanford construction camps. Documentation of the sludge disposal practice has not been located to date. Sampling at Spring 13 began in June 1945 and ended in July 1946. It is possible that Spring 13 was an incipient West Lake prior to the disposal of large quantities of water 

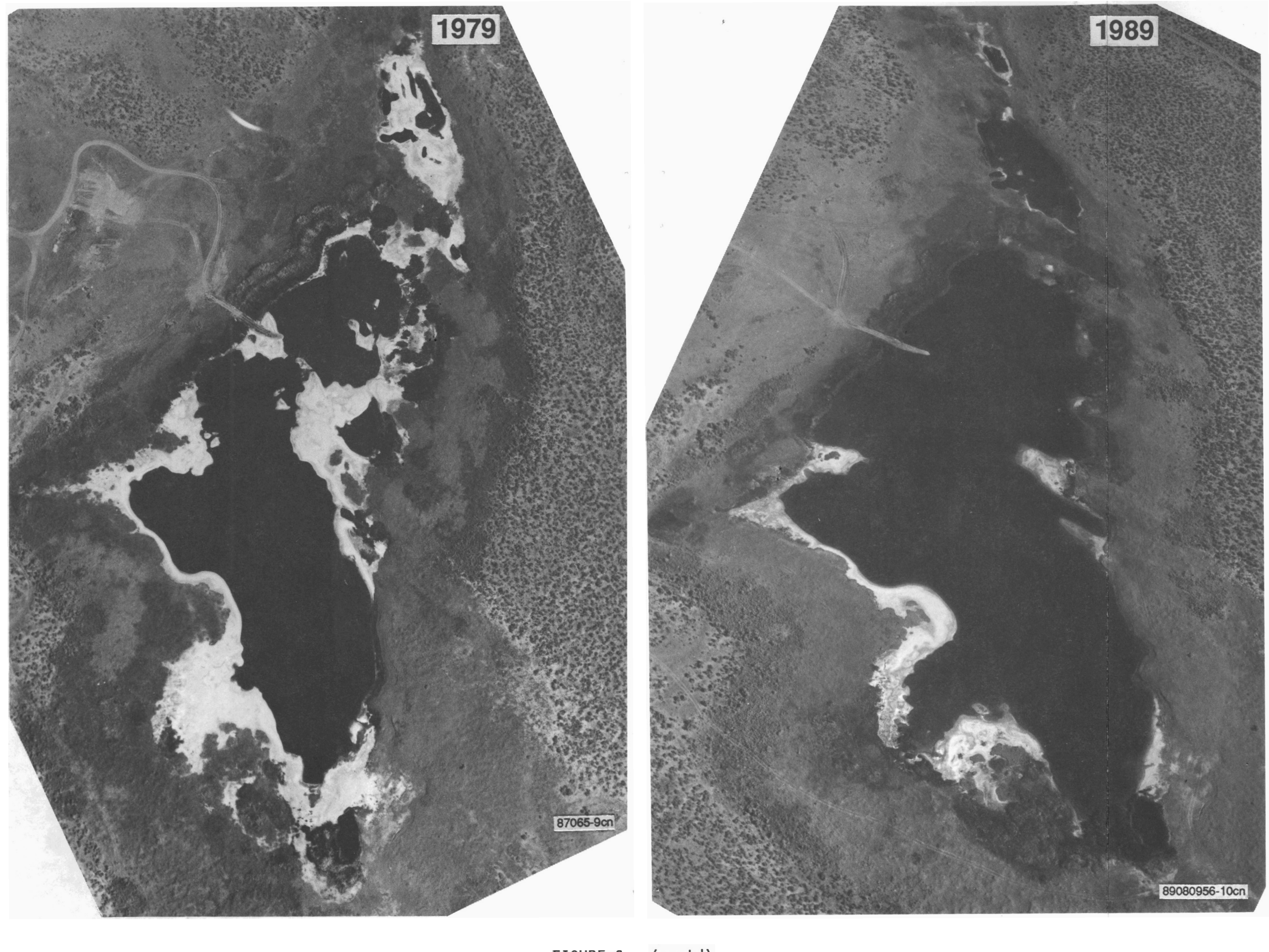

FIGURE 2 (contd) 


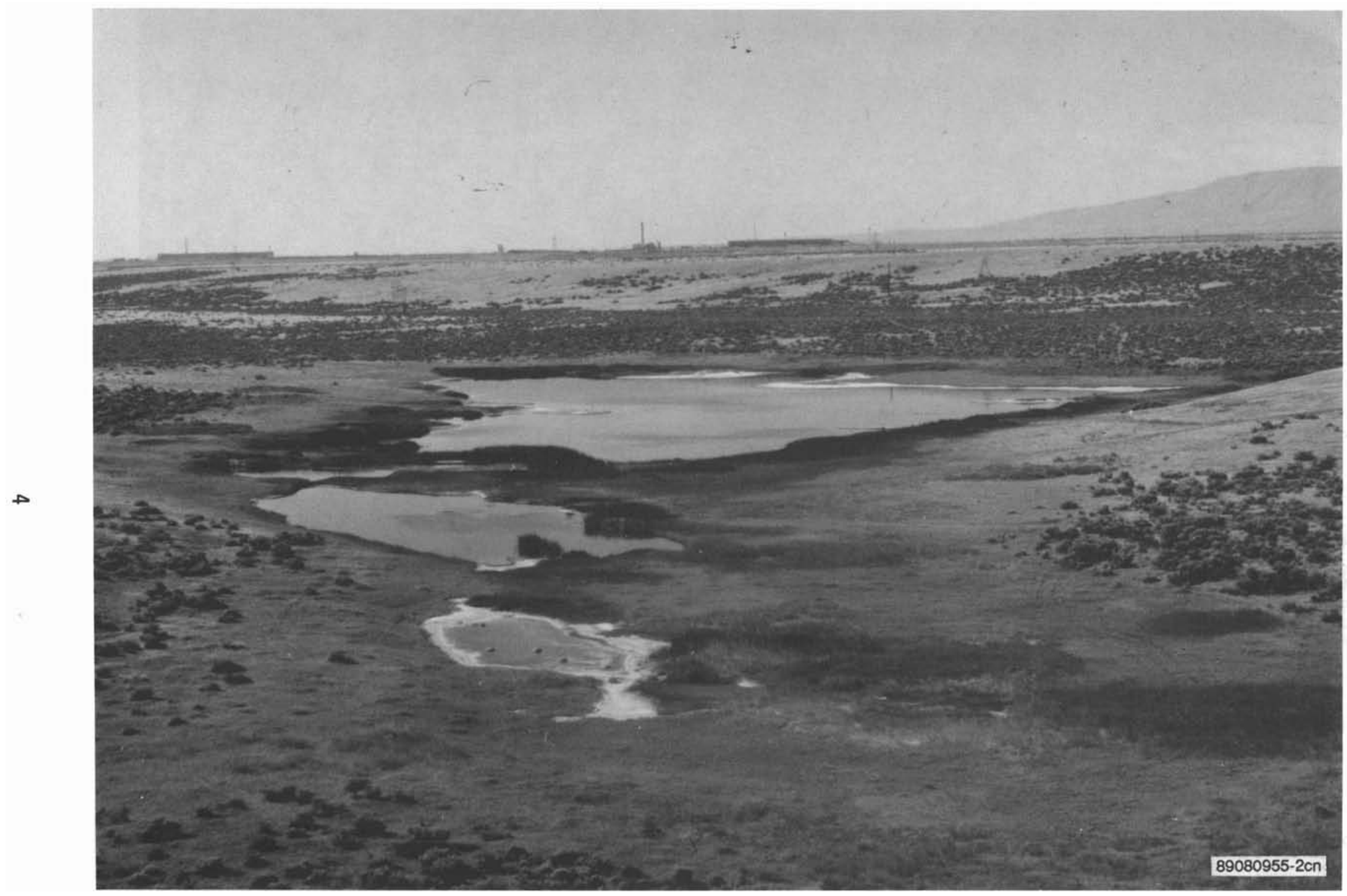

FIGURE 1. West Lake and Associated Pools (looking south), August 1989 
upgradient in the 200 Areas-beginning in 1945. The influence. of ground-water mounding in the 200 Areas at that time may have resulted in an increase in the elevation of the water table in the West Lake basin.

The surface of West Lake is continuous with the water-table surface (ERDA 1975). In 1957, waste water disposal to the then newly developed Gable Mountain Pond caused the water table to rise in the West Lake basin, and West Lake became a permanent pond soon after (Gephart et al. 1976; Strait and Moore 1982). Strait and Moore (1982) reported that water from West Lake was ${ }^{14} \mathrm{C}$ dated as modern (i.e., younger than 1950).

The pond has at times been designated a radiation control area because of relatively high levels of natural uranium. The extent of radiological and chemical contamination has been the subject of several earlier investigations (Gephart et a1. 1976; Emery and McShane 1978; Riley et a1. 1986). The purpose of this report is to evaluate past studies of the lake, the relationship of the lake to historical changes in the water table and ground-water chemistry, and the extent of past and current levels of contamination. Sampling was conducted in the West Lake basin, its underlying aquifers, and West Lake proper in August 1989. The objective was to further characterize the basin and expand the existing data to further define the degree that Hanford Site activities have affected the lake.

This report consists of a review of the hydrogeology of the West Lake basin, including an evaluation of past radiological studies of ground and surface water; an ecological profile of the lake and associated terrestrial habitat; a description of the current sampling program; and the sampling results. Appendixes $A, B$, and $C$ contain the data tables and profiles of the chemical constituents found in West Lake.

This investigation was conducted by the Pacific Northwest Laboratory (a) (PNL) Surface Environmental Surveillance Project for the Hanford Site.

(a) Pacific Northwest Laboratory is operated for the U.S. Department of Energy by Battelle Memorial Institute. 


\section{HMDROGEOLGY}

The unconfined aquifer near West Lake lies entirely within coarsegrained deposits of the Hanford formation and is approximately $15 \mathrm{~m}$ thick (Graham et a1. 1984). Extensive erosion caused by late-Pleistocene catastrophic flooding occurred in the vicinity of West Lake, removing the Elephant Mountain Member and the Rattlesnake Ridge interbed. This historic event exposed the underlying basalt to the unconfined aquifer (Strait and Moore 1982; Graham et al. 1984). The Rattlesnake Ridge interbed of the uppermost confined aquifer (Rattlesnake Ridge aquifer) lies just to the south of West Lake (Graham et al. 1984). The most productive and permeable confined aquifer beneath West Lake is the Mabton interbed, whose surface is approximately $67 \mathrm{~m}$ below ground surface (Gephart et a1. 1976).

Discharges of large amounts of waste water to Gable Mountain Pond and other surface impoundments and subsurface structures (ie., cribs) were associated with the startup of the plutonium-uranium (PUREX) plant in the 200 East Area in 1957. These discharges are believed to have caused the rise of the water table and the creation of West Lake as it is now known (Emery and McShane 1978). This theory is supported by a comparison of lake photographs for 1964, 1975 (low-level year), 1979, and 1989 (see Figure 2) with waterlevel data collected from wells in the vicinity of West Lake and Gable Mountain Pond (Figure 3). The hydrographs in Figure 3 indicate that the water table rose approximately $3 \mathrm{~m}$ between 1957 and 1969, then declined approximately $1 \mathrm{~m}$ between 1969 and 1983. The water table began rising again after 1983 and is currently about a meter below its 1969 level.

Gephart et al. (1976) report that the hydraulic gradient of the unconfined aquifer near West Lake sloped gently to the east before waste water was disposed to Gable Mountain and B Ponds. The Hanford hindcast water-table map for 1944 in the area just south of Gable Mountain also indicates an'easterly direction of ground-water flow (ERDA 1975). Ground-water flow in this area has since been directed northward through the gap between Gable Butte and 


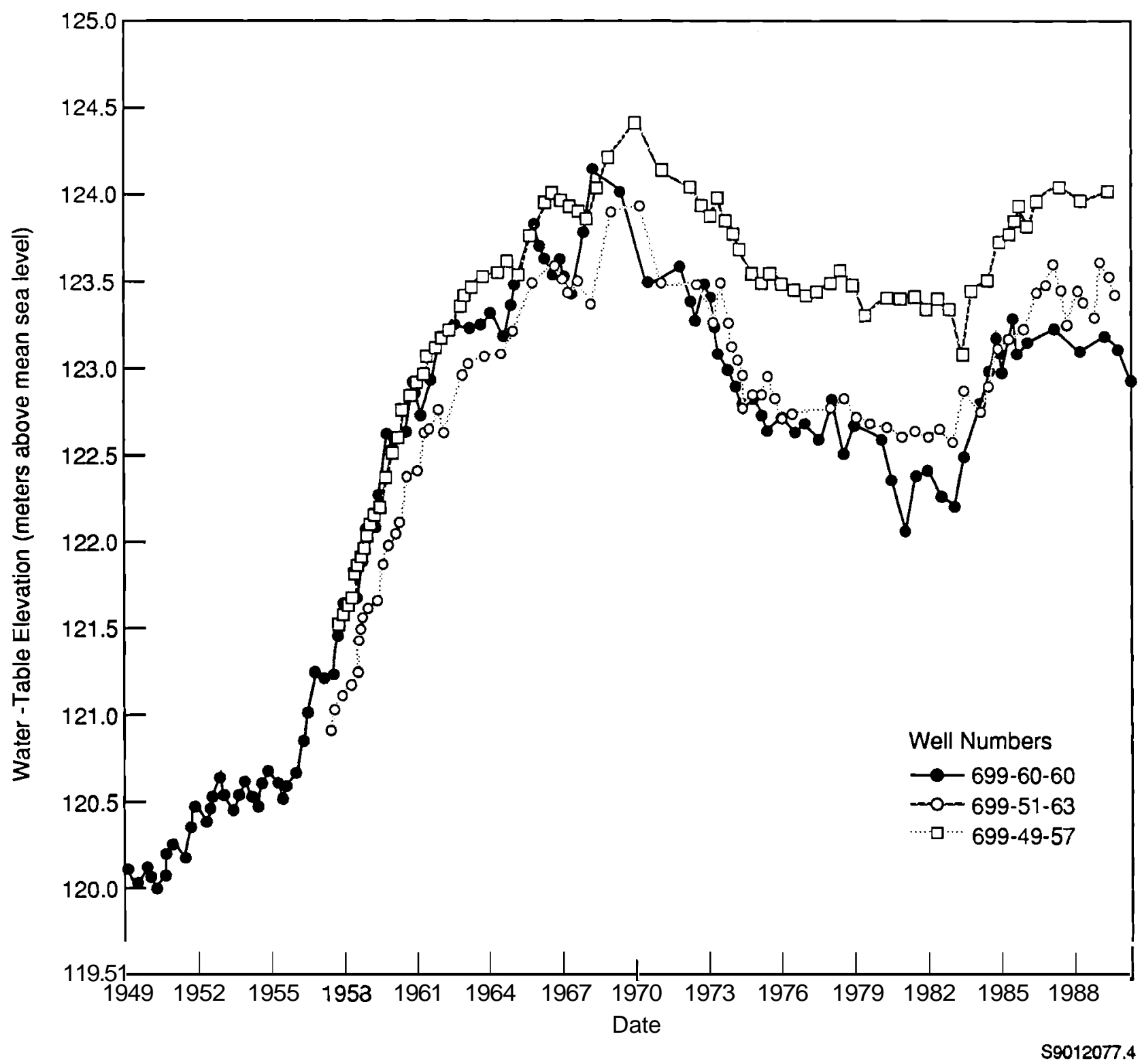

FIGURE 3. Ground-Water Level Fluctuations in Selected Well s Near West Lake, 1949 Through 1989

Gable Mountain (Gephart et a1. 1976). Waste-water discharge to Gable Mountain and $B$ Ponds raised the water table, partially blocking the natural easterly flow direction. Gephart et al. (1976) reported that the West Lake basin appeared to represent nearly stagnant ground-water conditions in 1976. 
A recent water-table map of the West Lake area-(June 1989; Figure 4) shows that unconfined ground water passing West Lake flows from the 200 East Area plateau north through the gap between Gable Butte and Gable Mountain. Figure 5 shows the potentiometric ${ }^{(a)}$ surface map of the underlying Rattlesnake Ridge confined aquifer for June 1989. These figures indicate that the flow direction of these two entirely different systems (i.e., unconfined and uppermost confined) are coincidental near West Lake (ie., flow is generally to the northwest for both systems).

It is possible that ground water may be moving up from deeper aquifers along fracture joints associated with the Gable Mountain anticline (Graham et a1. 1984). Ledgerwood and Deju (1976) indicated hydraulic interconnection between the uppermost confined aquifers and the unconfined aquifer due to the breaching of tilted basalt interbeds between Gable Butte and Gable Mountain. A comparison of the potentiometric surface of the Rattlesnake Ridge confined aquifer and the water table of the unconfined aquifer for June 1989 indicates an upward potential exists between the unconfined aquifer and the underlying Rattlesnake Ridge confined aquifer just south of West Lake. Graham et al. (1984) also reported that an upward potential of ground water existed beneath West Lake as a result of the Rattlesnake Ridge confined aquifer (and perhaps deeper aquifers) discharging to the unconfined aquifer.

\section{GROUND-WATER CHEMISTRY}

Historical chemical data for water samples collected from West Lake and the confined and unconfined aquifers near West Lake indicate the possibility of aquifer leakage between the uppermost confined aquifers and the overlying unconfined aquifer (Gephart et al. 1976). Water in West Lake is anomalously high in alkalinity and salt content; however, the ratios of the major constituents are similar to those in waters of the confined aquifers. The major buffering component of samples from well 699-60-57, located northwest of West Lake, is sodium carbonate, the same as the Mabton interbed (Graham et al. 1984). This may indicate that the deeper aquifers are discharging ground

(a) The potentiometric surface is the surface to which a given aquifer will rise by hydrostatic pressure. 


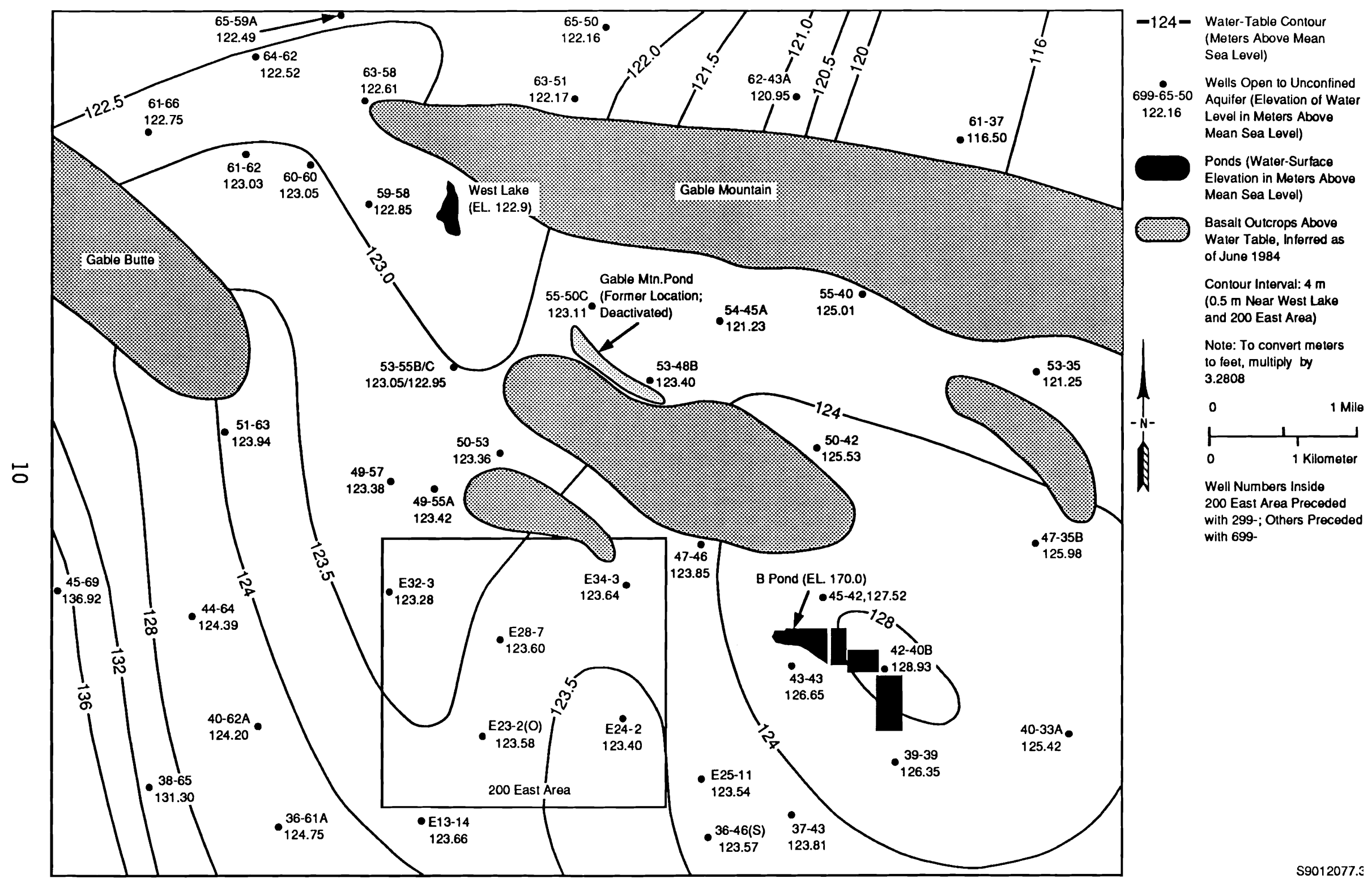

FIGURE 4 Water-Table Elevation Map, June 1989 (modified from Kasza and Schatz 1989) 

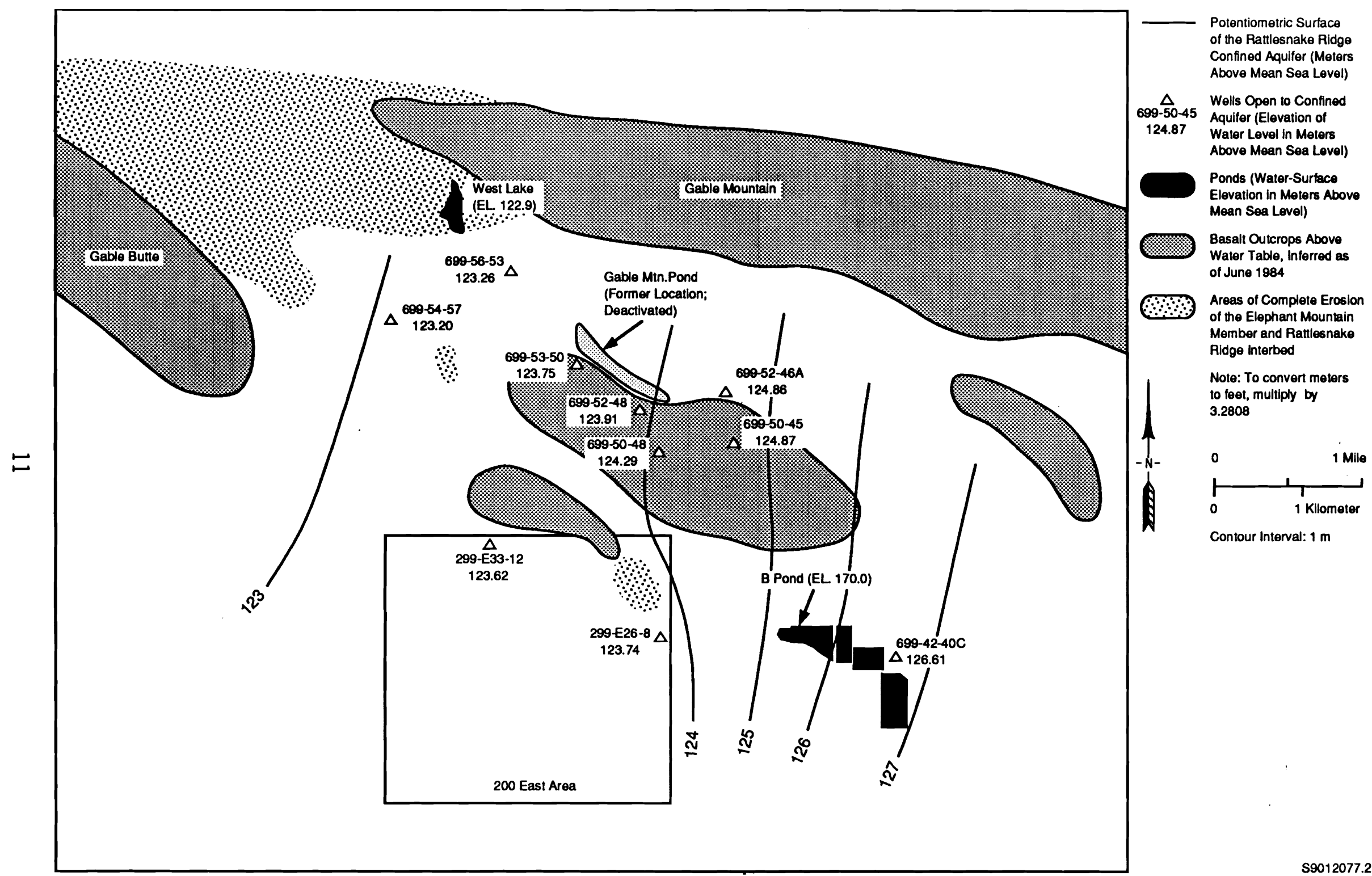

FIGURE 5. Potentiometric Surface Elevation Map, June 1989 modified from Kasza and Schatz 
water to the unconfined aquifer and West Lake. However, Early et a1. (1988) showed that downward flow between the unconfined aquifer and the Wanapum Basalt in the vicinity of West Lake occurs along Tractures 'associated with the Umtanum Ridge-Gable Mountain anticline. The Wanapum Basalt lies below the Mabton interbed. The Umtanum Ridge-Gable Mountain anticline is the most prominent structural feature in the area of West Lake.

Fuel reprocessing activities use large quantities of nitric acid, and the nitrate ion has been detected in ground water adjacent to the 200 East Area. Wells near West Lake indicate low concentrations of nitrate $\left(\mathrm{as}^{\mathrm{N}} \mathrm{N}_{3}^{-}\right)$; generally less than $20 \mathrm{mg} / \mathrm{L}$. The highest $\mathrm{NO}_{3}^{-}$levels were found in well 699-49-57, approximately 2,700 $\mathrm{m}$ south of West Lake, and ranged between 40 and $120 \mathrm{mg} / \mathrm{L}$ between 1985 and 1989 (see Appendix C, Figure C.6).

\section{AOUATIC ECOLOGY}

Very little information is available on the physical and biological characterization of West Lake. Emery and McShane (1978) investigated and reported the aquatic ecology of West Lake in 1975-1976. Their study involved a limnological characterization of the lake as well as a qualitative survey of the biota.

\section{Phvsical Characterization}

West Lake occupies an area of approximately $77,800 \mathrm{~m}^{2}$ (19.2 acres), with a mean depth of $0.4 \mathrm{~m}(1.3 \mathrm{ft})$; the volume is $31,100 \mathrm{~m}^{3}$ (25.1 acre-feet) (Emery and McShane 1978). The dimensions of West Lake vary directly with changes in elevation of the underlying water table.

As indicated previously, West Lake appears to have been formed by a rise in elevation of the water table in the 200 Areas as a result of discharges of water to the unconfined aquifer. An additional minor source of water to the lake may be snow runoff, following periods of unseasonable, rapid warming in winter.

\section{Water Chemistrv}

Water in the lake is very saline and alkaline $(\mathrm{pH}$ range $=9.7$ to 10.0$)$, a characteristic resulting from high rates of evaporation, stagnation, low 
percolation, and possible infusion of water from underlying aquifers. Mean alkalinity ( $\pm 95 \%$ confidence interval) by titration is $9,000 \pm 1,900 \mathrm{mg} \mathrm{CaCO}_{3}$ equivalents/L (Table 1). Conductivity measurements also indicate a high level of dissolved solids: 23,000 to $25,000 \mu$ mhos $/ \mathrm{cm}$ at $25^{\circ} \mathrm{C}$. The $14,550-\mu \mathrm{mhos} / \mathrm{cm}$

TABLE 1. Water Quali ty Parameters of West Lake(a)

\begin{tabular}{|c|c|c|c|c|c|}
\hline Parameter & Units & $1975-1976$ (b) & $1976^{\text {(c) }}$ & $1987^{(d)}$ & $1989^{(e)}$ \\
\hline $\begin{array}{l}\text { pH } \\
\text { Alkalinity } \\
\text { Hardness } \\
\text { Conductivity } \\
\text { Total dissolved }\end{array}$ & $\begin{array}{l}\text { unitless } \\
\mathrm{mg} / \mathrm{L} \\
\mathrm{mg} / \mathrm{L} \\
\mu \mathrm{mhos} / \mathrm{cm}\end{array}$ & $\begin{array}{l}9.7 \text { to } 10.0 \\
9,009 \\
122 \\
229,700\end{array}$ & $\begin{array}{l}9.6 \\
\text { NA } \\
\text { NA } \\
14,550\end{array}$ & $\begin{array}{l}9.5 \text { to } 9.6 \\
\text { NA } \\
\text { NA } \\
23,000 \text { to } 25,000(f)\end{array}$ & $\begin{array}{l}\text { NA } \\
\text { NA } \\
\text { NA } \\
\text { NA }\end{array}$ \\
\hline $\begin{array}{l}\text { solids } \\
\text { Calc ium } \\
\text { Magnesium } \\
\text { Sodium } \\
\text { Potassium } \\
\text { Carbonate } \\
\text { Total carbon } \\
\text { Total organic }\end{array}$ & $\begin{array}{l}\mathrm{mg} / \mathrm{L} \\
\mathrm{mg} / \mathrm{L} \\
\mathrm{mg} / \mathrm{L} \\
\mathrm{mg} / \mathrm{L} \\
\mathrm{mg} / \mathrm{L} \\
\mathrm{mg} / \mathrm{L} \\
\mathrm{mg} / \mathrm{L}\end{array}$ & $\begin{array}{l}\text { NA } \\
\text { NA } \\
\text { NA } \\
\text { NA } \\
\text { NA } \\
\text { NA } \\
\text { NA }\end{array}$ & $\begin{array}{l}15,410 \\
5 \\
13 \\
7,000 \\
400 \\
5,860 \\
N A\end{array}$ & $\begin{array}{l}\text { NA } \\
\text { NA } \\
\text { NA } \\
4,120 \text { to } 4,260 \\
209 \text { to } 219 \\
\text { NA } \\
\text { NA }\end{array}$ & $\begin{array}{l}\text { NA } \\
7.72 \\
10.7 \\
7,520 \\
325 \\
\text { NA } \\
1,880\end{array}$ \\
\hline $\begin{array}{l}\text { carbon } \\
\text { Sulfate } \\
\text { Sulfide } \\
\text { Chloride } \\
\text { Fluoride } \\
\text { Nitrate } \\
\text { Ammonium } \\
\text { Phosphorus }\end{array}$ & $\begin{array}{l}\mathrm{mg} / \mathrm{L} \\
\mathrm{mg} / \mathrm{L} \\
\mathrm{mg} / \mathrm{L} \\
\mathrm{mg} / \mathrm{L} \\
\mathrm{mg} / \mathrm{L} \\
\mathrm{mg} / \mathrm{L} \\
\mathrm{mg} / \mathrm{L} \\
\mu \mathrm{g} P O\end{array}$ & $\begin{array}{l}\text { NA } \\
\text { NA } \\
\text { NA } \\
\text { NA } \\
\text { NA } \\
\text { NA } \\
2.61\end{array}$ & $\begin{array}{l}600 \\
1,375 \\
N A \\
2,080 \\
158 \\
0.25 \\
\text { NA }\end{array}$ & $\begin{array}{l}113 \\
2,410 \text { to } 3,060 \\
\mathrm{NA} \\
1,230 \text { to } 1,640 \\
76 \text { to } 91 \\
1.7-1.8 \\
\mathrm{NA}\end{array}$ & $\begin{array}{l}\text { NA } \\
3,800 \\
1.58 \\
2,000 \\
N A \\
<5.0 \\
0.367\end{array}$ \\
\hline Silicate & $\begin{array}{c}\mathrm{P} / \mathrm{L}^{4} \\
\mathrm{mg} \mathrm{SiO}_{\mathrm{Si}^{-}}-\mathrm{L}^{-}\end{array}$ & 2,160 & NA & 6,600 & NA \\
\hline
\end{tabular}

\footnotetext{
(a) See Table 2 for two eastern Washington saline lakes.

(b) Mean values from Emery and McShane (1978), also reported in Rogers and Rickard (1977).

(c) Gephart et al. (1976).

(d) Data collected by EG\&G Idaho, Idaho Fal1s, Idaho.

(e) Data collected for this study.

(f) Values reported as $\mu$ Seimens; $1 \mu$ Seimens $=1 \mu \mathrm{mhos} / \mathrm{cm}$.

$\mathrm{NA}=$ Not analyzed.
} 
TABLE 2. Water quality Parameters of Lake Lenore and Soap' Lake

\begin{tabular}{|c|c|c|c|c|c|c|c|c|c|}
\hline \multirow[b]{2}{*}{ Parameter } & \multirow[b]{2}{*}{ Units } & \multicolumn{4}{|c|}{ Lake Lenore } & \multicolumn{4}{|c|}{ Soap Lake } \\
\hline & & $1949^{(a)}$ & $1950-51^{(b)}$ & $1954^{(a)}$ & $1956^{(a)}$ & $1949^{(a)}$ & $1950-51^{(b)}$ & $1954^{(a)}$ & $1956^{(a)}$ \\
\hline pH & unit less & 9.7 & $9.7-10.0$ & 9.8 & 9.7 & 9.8 & $9.4-10.0$ & 10.0 & 10.0 \\
\hline Conductivity & $\mu \mathrm{mhos} / \mathrm{cm}$ & 23,286 & 14,158 & 10,640 & 43.000 & 30.087 & 24,980 & NA & $N A$ \\
\hline Total dissolved & & & & & & & & & \\
\hline solids & $\mathrm{mg} / \mathrm{L}$ & 18,600 & 14.080 & 11,040 & 7.500 & 38.954 & 35,280 & 25,440 & 20.600 \\
\hline Calcium & $\mathrm{mg} / \mathrm{L}$ & 9 & 10.2 & 8 & 5 & 5 & 20.6 & 8 & 5 \\
\hline Magnes i um & $\mathrm{mg} / \mathrm{L}$ & 20 & 13.8 & 20 & 15 & 17 & 8.2 & 20 & 16 \\
\hline Sodi um & $\mathrm{mg} / \mathrm{L}$ & 6.969 & 5.129 & 3.887 & 2.622 & 14,260 & 11,868 & 8,763 & 7.291 \\
\hline Potassium & $\mathrm{mg} / \mathrm{L}$ & 508 & 438 & 321 & 239 & 739 & 1,134 & 774 & 602 \\
\hline Carbonate & $\mathrm{mg} / \mathrm{L}$ & 3,990 & 3,000 & 1,746 & 936 & 7,440 & 6,870 & 4,050 & 3,360 \\
\hline Bicarbonate & $\mathrm{mg} / \mathrm{L}$ & 4,636 & 3,544 & 3.221 & 2,885 & 6.893 & 5,209 & 5,020 & 3.788 \\
\hline Sulfate & $\mathrm{mg} / \mathrm{L}$ & 2,923 & 2,112 & 1,627 & 1,378 & 6.960 & 6,240 & 4,560 & 3,782 \\
\hline Chloride & $\mathrm{mg} / \mathrm{L}$ & 1,856 & 1,438 & 1,993 & 724 & 5,183 & 5,467 & 3,444 & 2.570 \\
\hline Nitrate & $\mathrm{mg} / \mathrm{L}$ & NA & NA & 8.7 & NA & NA & NA & 8.7 & NA \\
\hline Phosphorus & $\mu g \mathrm{PO}_{4}-\mathrm{P} / \mathrm{L}$ & NA & $2.8-195^{(c)}$ & NA & NA & NA & $-2-2,985^{(c)}$ & NA & NA \\
\hline
\end{tabular}

\footnotetext{
(a) Castenholtz (1960).

(b) Anderson (1958); all values. except $\mathrm{pH}$ and $\mathrm{PO}_{4}$, collected in November 1950.

(c) Values greatly influenced by seasonal fluctuations or stratification; values reported as $\mu \mathrm{g}$ atoms $\cdot \mathrm{L}^{-1}$. $\mathrm{NA}=$ Not analyzed.
}

reported by Emery and McShane (1978) appear suspect. Water hardness, (a) in contrast, was $122 \pm 8 \mathrm{ng} \mathrm{CaCO}_{3}$ equival ents/L (Emery and McShane 1978). The relatively low hardness is a result of calcium removal by precipitation of calcium carbonate because of high $\mathrm{pH}$ and algal photosynthesis.

In comparison to other saline lakes in eastern Washington, West Lake has a more saline environment. Lake Lenore and Soap Lake (see Table 2), highly saline lakes located approximately $220 \mathrm{~km}(138 \mathrm{mi})$ north of West Lake in arid, eastern Washington, were studied extensively in the late forties and fifties (Anderson 1958; Castenholz 1960; Edmonson and Anderson 1965). The water chemistry of West Lake is very similar to these larger, saline lakes; the main differences are conductivity and dissolved salts. The differences in conductivity are best explained by the fact that West Lake is small and shallow, while Lake Lenore and Soap Lake are considerably larger, deeper, and subject to stratification and formation of chemoclines. The mean depth of Lake Lenore

(a) Hardness is total divalent cations measured by EDTA (ethylenediamine tetraacetic acid) titration. Alkalinity is the capacity of water to neutralize acid. Both are expressed in terms of $\mathrm{CaCO}_{3}$ equivalents/L. 
was $6.5 \mathrm{~m}$ and Soap Lake was $10.02 \mathrm{~m}$ deep (Anderson 1958). Both lakes have established hypolimnions, with considerably higher solute concentrations than indicated by the surface measurements given in Table 2. Moreover, during the years these data were collected, the lakes were undergoing continued dilution from regional irrigation practices.

\section{Nutrient Balance}

The availability of plant nutrients is significant from the standpoint of supporting phytoplankton and, to a lesser extent, vascular aquatic plants. Total phosphorus levels in 1976 were 2,160 $\pm 140 \mu \mathrm{g} \mathrm{PO}{ }_{4}-\mathrm{P} / \mathrm{L}$, while the concentration of soluble phosphorus (orthophosphate) was $2,050 \pm 180 \mu \mathrm{g} \mathrm{PO}{ }_{4}-\mathrm{P} / \mathrm{L}$. These levels represent a very high content of phosphorus. Generally, levels greater than $100 \mu \mathrm{g} \mathrm{PO}_{4}-\mathrm{P} / \mathrm{L}$ constitute a hypereutrophic system. Mean reported values for ammonia $\left(\mathrm{NH}_{3}-\mathrm{N}\right)$ were $2.61 \mathrm{mg} / \mathrm{L}$, and nitrate $\mathrm{NO}$ ) levels were 1.7 to $1.8 \mathrm{mg} / \mathrm{L}$. Collectively, the total amount of inorganic nitrogen, as both $\mathrm{NH}_{3}$ and $\mathrm{N}$ place the trophic status of West Lake as hypereutrophic. Various authors have speculated that the high phosphorus and nitrogen levels are the result of disposal of sanitary sewage sludge to the West Lake basin (Rogers and Rickard 1977; Emery and McShane 1978; Meinhardt and Frostenson 1979).

\section{Productivity}

The planktonic community of West Lake is dominated by periphyton, an attached colony dominated by diatoms and fresh-water brown algae. The dominance of diatoms and algae is characteristic of alkaline and saline lakes and, with few taxonomic exceptions, parallels algal taxonomic profiles of Lake Lenore and Soap lake (Castenholtz 1960; Emery and McShane 1978). Emery and McShane (1978) noted that periphyton colonization rates (expressed as $17 \pm 10 \mu \mathrm{g}$ chlorophyll $\alpha / \mathrm{cm}^{2}$ ) were relatively low compared to other waste ponds on the Hanford Site. Other ponds at Hanford had mean colonization rates 2.5 to 4.3 times higher than West Lake. The low level of periphyton colonization may be attributed to the high level of dissolved salts in West Lake.

No rooted submergent vascular plants have been observed in West Lake. Three-spined bulrush had colonized the southernmost tip of West Lake in 1964 (see Figure 2). In comparison, by 1989, bulrush had spread to sections of all 
shores of the lake and to areas where springs emerge in the northern tip of the West Lake basin. Emery and McShane (1978) reported that cattails, Typha sp., inhabited the pond in 1976; however, cattails presently are not found at West Lake.

\section{Fauna}

Emery and McShane (1978) observed fresh-water annelids, 07igochaeta, and flying insects, including damsel flies, Odonata, back swimmers, Notonectidae, water boatman, Corizidae, caddisfly, Trichoptera, midge fly, Chironomidae, and shore fly, Ephydridae. Segmented worms, 07igochaeta, were reported as a notably abundant organism. No record was found that documented the observation of fish in West Lake.

\section{TERRESTRIAL EOOLOGY}

There have been no definitive studies of the terrestrial ecology of the West Lake basin. Inspection of soil maps indicates that the areas adjacent to the basin consist of Ephrata sandy loam or Burbank sandy loam (Hajek 1966). A band of salt-tolerant vegetation encircles West Lake, and is dominated by salt grass, Distichlis stricta. The zonation changes to a distinct sagebrush, Artemesia tridentata,/grass zone, consisting of bunch grass species and cheatgrass, Bromus tectorum, farther away from salt-influenced soil (see Figures 1 and 2). Plantain, Plantageo elongatum, an introduced species, and rattle box, Swainsona salsula, are found in other areas around the lake. Three-spined bulrush inhabits moist areas, where springs emerge and along segments of the shoreline.

Terrestrial fauna include those common to the Hanford Site and are summarized in Cushing (1989). Of particular significance to this study are populations of American coot, Fulica americana, that breed on the pond. Coot eggshells from West Lake and Morgan Lake, a control 1ake, were monitored for ${ }^{90} \mathrm{Sr}$ and uranium isotopes. Ducks, shorebirds, blackbirds, and swallows a7so frequent the Take (Fitzner and Price 1973; Fitzner and Rickard 1975). Morgan Lake is located approximately $76 \mathrm{~km}$ (48 mi) northeast of West Lake on the Columbia National Wildlife Refuge. 


\section{METHODS}

All sampling activities were performed by PNL personnel, and chemical and radiological analyses were performed by United States Testing Company, Inc. Data on mass spectroscopy were provided by PNL. Samples were collected in August 1989.

\section{GROUND WATER}

Ground-water samples were collected from wells 699-53-55A, 699-56-53, 699-59-58, and 699-60-57 in the vicinity of West Lake in August 1989 (Figure 6). We11 699-56-53 is open to the Rattlesnake Ridge confined aquifer, wells 699-53-55A and 699-60-57 are open to the full thickness of the unconfined aquifer, and well 699-59-58 is open to the uppermost part of the unconfined aquifer. Of the three wells open to the unconfined aquifer, two (699-59-58 and 699-60-57) are considered downgradient from the lake (McGhan 1989). The depths, monitored aquifer description, and coordinates of the wells used in this study are listed in Table 3.

Ground-water samples were analyzed for cations, anions, trace metals, and radionucl ides (Table 4). Unfiltered ground-water samples were collected for anion analyses, and both filtered and unfiltered samples were collected for cation and trace metal analyses.

A11 1989 ground-water samples were collected from we11s 699-53-55A, 699-56-53, 699-59-58, and 699-60-57 by methods similar to those described in PNL (1989). These PNL methods follow establ ished guidelines for sampling ground water described in EPA (1986). The wells were not purged, and sample collection was limited to "grab" samples.

The purging of wells is designed to ensure the removal of stagnant water and allow the collection of a "representative" ground-water sample adjacent to the well. Because purging of the wells was not conducted, the ground-water samples may not be representative of ground water in the aquifer, and the analytical results may be indicative of stagnant water conditions. Under 


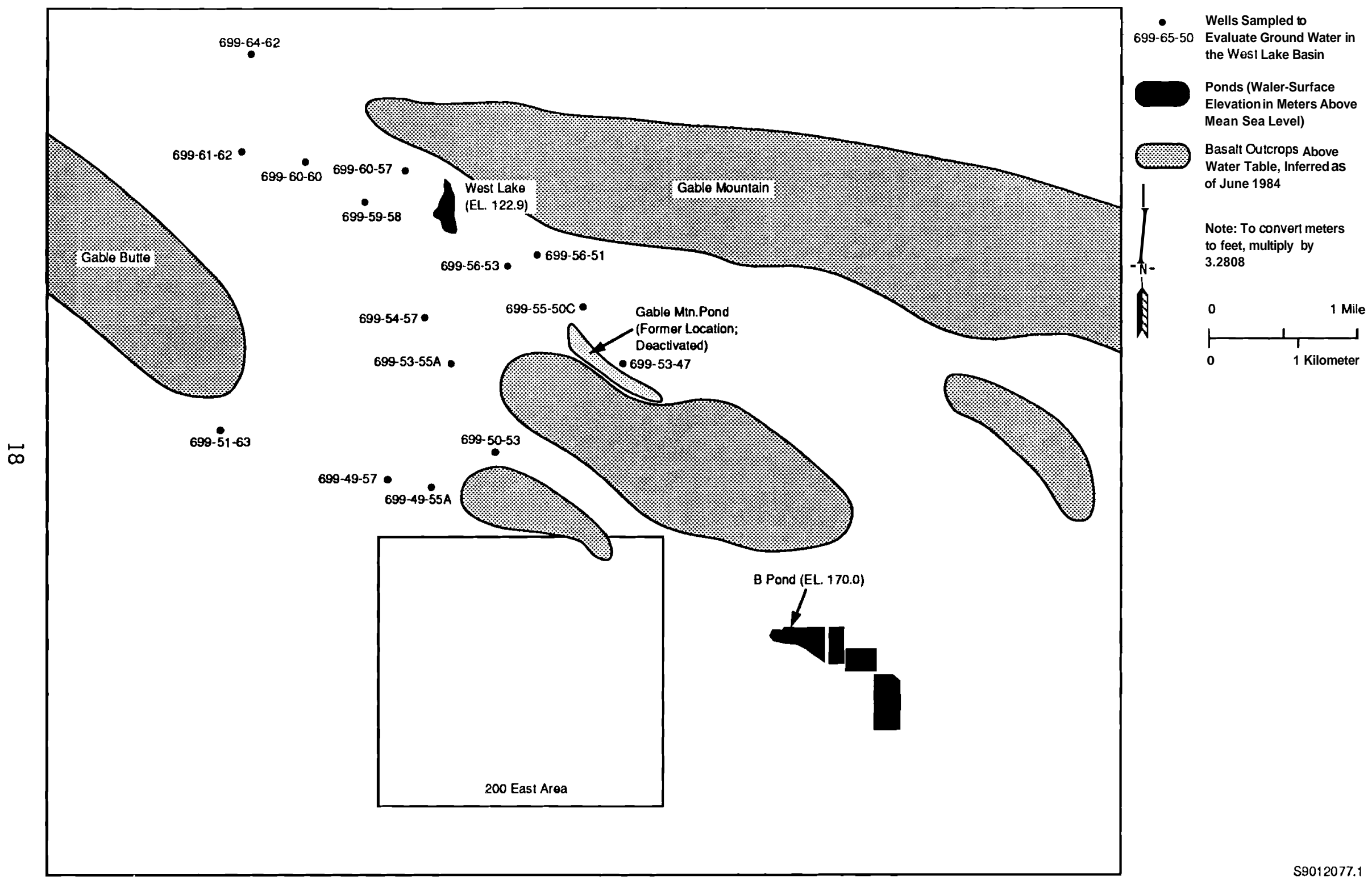

FIGURE 6. Location Map of Wells Used for Evaluating Ground Water in the West Lake Basin 
TABLE 3. Wells Sampled to Evaluate Ground Water in the Vicinity of the West Lake Basin

\begin{tabular}{|c|c|c|c|c|c|c|}
\hline \multirow[b]{2}{*}{ Well Number } & \multirow{2}{*}{$\begin{array}{c}\text { Depth of } \\
\text { Completion } \\
\text { Interval (m) } \\
\end{array}$} & \multirow[b]{2}{*}{ Monitored Aquifer } & \multicolumn{2}{|c|}{$\begin{array}{c}\text { Hanford } \\
\text { Plant Coordinates }\end{array}$} & \multicolumn{2}{|c|}{$\begin{array}{c}\text { Iambert } \\
\text { Coordinates }(a)\end{array}$} \\
\hline & & & North & West & North & West \\
\hline $699-49-55 A$ & 38.1 to 41.1 & Shal low-unconf ined & 48,803 & 54,926 & 465,742 & $1,195,446$ \\
\hline 699-49-57 & 43.9 to 49.1 & Shal low-deep unconfined & 48,600 & 56,913 & 465,747 & $1,195,525$ \\
\hline $699-50-53$ & 43.3 to 48.5 & Shal low-unconf ined & 49,919 & 53,267 & 465,770 & $1,195,379$ \\
\hline $699-51-63$ & 47.9 to 55.8 & Sha 1 low-unconf i ned & 50,667 & 63,060 & 465,817 & $1,195,768$ \\
\hline $699-53-55 A^{(b)}$ & 50.3 to 82.3 & Sha 1 low-deep unconfined & 53,096 & 55.014 & 465,858 & $1,195,448$ \\
\hline $699-55-50 \mathrm{C}$ & 10.7 to 17.1 & Shal low-unconfined & 55,017 & 49,940 & 465.911 & $1,195,245$ \\
\hline $699-56-51$ & 16.8 to 32.8 & Shal low-deep unconfined & 56,343 & 50.500 & 465.938 & $1,195,267$ \\
\hline $699-56-53(b)$ & 57.9 to 82.3 & Confined & 56,772 & 52,779 & 465,948 & $1,195,357$ \\
\hline $699-59-58$ (b) & 25.9 to 30.5 & Shal low-unconf ined & 59,445 & 57.763 & 466,019 & $1,195,555$ \\
\hline $699-60-57^{(b)}$ & 16.8 to 46.9 & Shal low-deep unconfined & 60,030 & 59,964 & 466.059 & $1,195,508$ \\
\hline $699-60-60$ & 36.5 to 33.5 & Sha 1 low-unconfi ned & 60,030 & 59,964 & 466,051 & $1,195,642$ \\
\hline $699-61-62$ & 26.2 to 30.5 & Shal low-unconfi ned & 61,062 & 62,217 & 466.066 & $1,195,731$ \\
\hline $699-64-62$ & 27.4 to 33.5 & Shal low-unconf ined & 65,000 & 61.746 & 466,155 & $1,195,711$ \\
\hline
\end{tabular}

(a) Also referred to as Washington Coordinate System.

(b) Wells sampled in August 1989.

TABLE 4. Laboratory Analyses Performed on Ground-Water Samples

Analytical

Cateqorv

Cations

Anions

Trace metals

Radi onuclides

\section{Anal ytical Species}

Calcium, magnesium, sodium, potassium, iron

Chloride, sulfate, nitrate, nitrite, fluoride, phosphate, bromide

Aluminum, antimony, barium, beryllium, boron, cadmium, chromium, copper, cobalt, lithium, manganese, molybdenum, nickel, tin, titanium, silver, silicon, strontium, vanadium, zinc, zirconium

$$
{ }^{3} \mathrm{H},{ }^{60} \mathrm{Co},{ }^{90} \mathrm{Sr},{ }^{99} \mathrm{Tc},{ }^{106} \mathrm{Ru},{ }^{137} \mathrm{Cs},{ }^{234} \mathrm{U}, 235_{\mathrm{U}},{ }^{238_{\mathrm{U}}}
$$


stagnant water conditions, chemical reactions (e.g., redox reactions, desorption, adsorption) between the well materials and chemicals in the ground water may influence the interpretation of the ground-water results.

Ground-water grab samples (filtered and unfiltered) were collected from well 699-56-53 with a Teflon bailer and from the other three wells (699-53-55A, 699-59-58, and 699-60-57) with submersible pumps. Cation, trace metal, and radionuclide samples were preserved at the time of sample collection with a nitric acid solution. Filtered samples were obtained with a $0.45-\mu \mathrm{m}$ pore-sized filter. Duplicate samples were collected from each well, and were analyzed to estimate the variability caused by the laboratory measurement technique and as a check for gross errors. The $\mathrm{pH}$, temperature, and electrical conductivity of the sample water were measured in the field at the time of sample collection.

\section{WEST LAKE BASIN}

For the purposes of this study, the West Lake basin includes West Lake and the zone of salt grass surrounding the lake (Figure 7). Sample stations were established on two transects within the basin for soil and vegetation samples. The north transect contained six sites situated from the northernmost pool to the area where sagebrush starts to grow. The south transect radiated in a southern direction from a stand of bulrush to where sagebrush was first found. Terrestrial sample collection sites (Table 5) were numbered from north to south (N1 through N6 and S1 through S5). Two samples of salt deposits also were collected adjacent to N6. Water and sediment samples were collected from nine stations, designated $L 1$ through $L 9$, located in the main body of West Lake and in three peripheral pools.

\section{SAMPLE ANALYSES}

\section{Radiological Analyses}

Table 6 summarizes the types of radiochemical analyses performed on the samples. Germa scans provided information on ${ }^{40} \mathrm{~K},{ }^{60} \mathrm{Co}{ }^{95} \mathrm{Zr}{ }^{95} \mathrm{Nb},{ }^{106} \mathrm{Ru}$, ${ }^{134} \mathrm{Cs},{ }^{137} \mathrm{Cs},{ }^{154} \mathrm{Eu},{ }^{155} \mathrm{Eu},{ }^{212} \mathrm{~Pb}$, and ${ }^{214} \mathrm{~Pb}$. Other radionuclides were sampled for in specific environmental matrices: ${ }^{3} \mathrm{H},{ }^{90} \mathrm{Sr},{ }^{99} \mathrm{Tc}$, and isotopes 


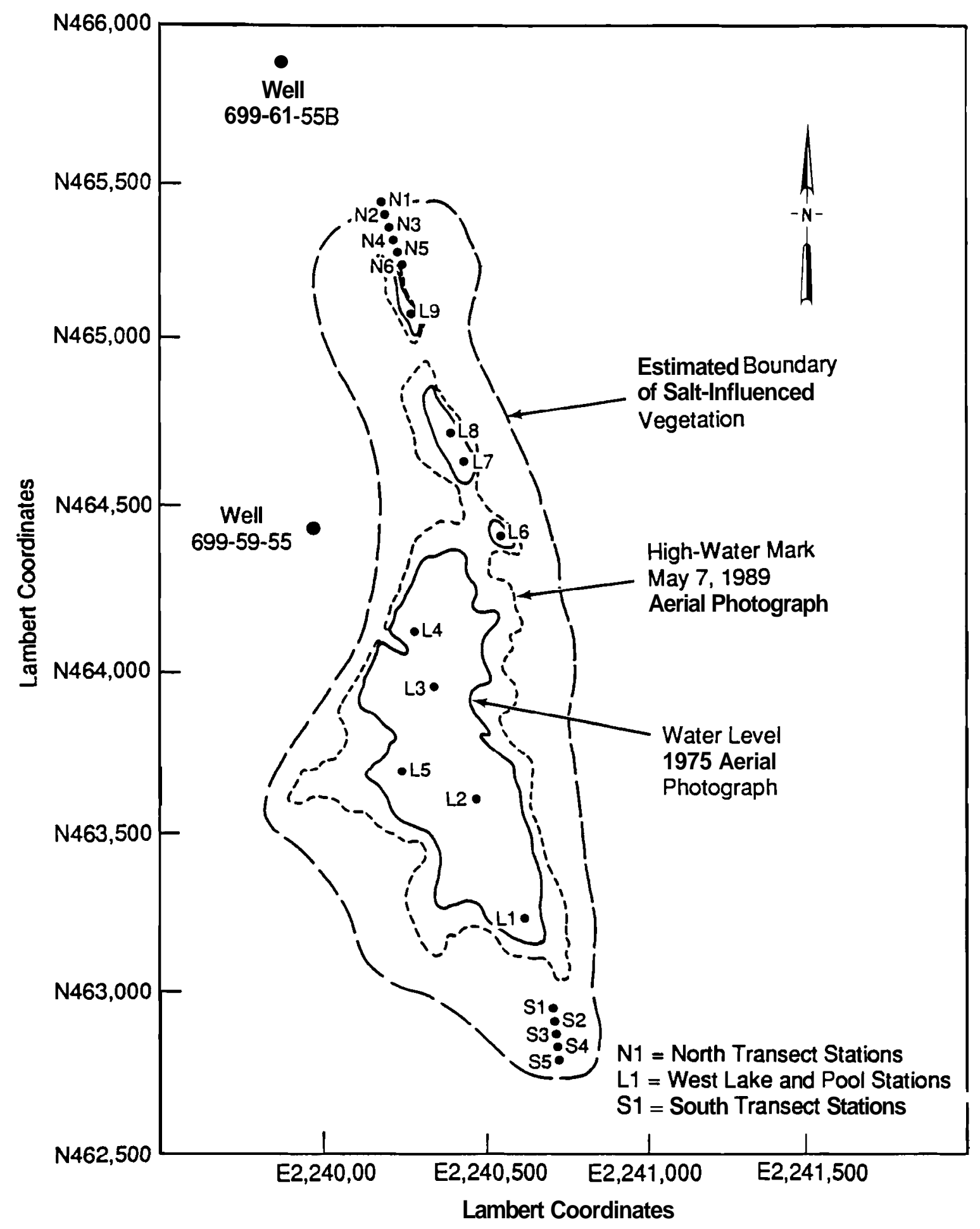

FIGURE 7. Location of Sample Sites for Sediment, Water, Soil, and Vegetation 
TABLE 5. Primary Surface Environmental Sample Sites in the West Lake Basin Sample Lambert Coordinates

\begin{tabular}{|c|c|c|}
\hline Site & North & East \\
\hline $\begin{array}{l}\text { S1 } \\
\text { S2 } \\
\text { S3 } \\
\text { S4 } \\
\text { S5 }\end{array}$ & $\begin{array}{l}462,786 \\
462,824 \\
462,864 \\
462,902 \\
462,942\end{array}$ & $\begin{array}{l}2,240,744 \\
2,240,738 \\
2,240,732 \\
2,240,726 \\
2,240,718\end{array}$ \\
\hline $\begin{array}{l}\text { N1 } \\
\text { N2 } \\
\text { N3 } \\
\text { N4 } \\
\text { N5 } \\
\text { N6 }\end{array}$ & $\begin{array}{l}465,425 \\
465,392 \\
465,354 \\
465,317 \\
465,279 \\
465,242\end{array}$ & $\begin{array}{l}2,240,210 \\
2,240,205 \\
2,240,217 \\
2,240,229 \\
2,240,241 \\
2,240,252\end{array}$ \\
\hline $\begin{array}{l}\text { L1 } \\
\text { L2 } \\
\text { L3 } \\
\text { L4 } \\
\text { L5 } \\
\text { L6 } \\
\text { L7 } \\
\text { L8 } \\
\text { L9 }\end{array}$ & $\begin{array}{l}463,223 \\
463,590 \\
463,939 \\
464,108 \\
463,695 \\
464,417 \\
464,651 \\
464,739 \\
465,134\end{array}$ & $\begin{array}{l}2,240,631 \\
2,240,494 \\
2,240,363 \\
2,240,299 \\
2,240,241 \\
2,240,585 \\
2,240,486 \\
2,240,427 \\
2,240,321\end{array}$ \\
\hline
\end{tabular}

\begin{tabular}{cccc}
\multicolumn{4}{c}{ Samples } \\
Soil & Veqetation & Water & Sediment \\
$x$ & $x$ & & \\
$x$ & $x$ & & \\
$x$ & $x$ & & \\
$x$ & $x$ & & \\
$x$ & $x$ & &
\end{tabular}

TABLE 6. Matrix of Samples Collected from the West Lake Basin for Radioisotopic Analyses, 1989

\begin{tabular}{|c|c|c|c|c|c|c|c|}
\hline Sample Type & $\begin{array}{l}\text { Gamma } \\
\text { Scan }\end{array}$ & $\begin{array}{l}\text { Low- } \\
\text { Energy } \\
\text { Photon } \\
\end{array}$ & $\frac{\text { Uranium Isotopes }}{\alpha-\text { Spectrometry }}$ & $\begin{array}{c}\text { Mass } \\
\text { Spectroscopy }\end{array}$ & $\underline{3_{H}}$ & ${ }^{90} S r$ & ${ }^{99} \mathrm{Tc}$ \\
\hline Soi 1 & $x$ & $x$ & & & & $x$ & \\
\hline Vegetation & $x$ & & $x$ & & & $x$ & \\
\hline Sediment & $x$ & & $x$ & & & & \\
\hline Salt deposit & $x$ & & $x$ & & & $x$ & \\
\hline Lake water & $x$ & & $x$ & $x$ & $x$ & $x$ & $x$ \\
\hline Ground water & $x$ & & $x$ & & $x$ & $x$ & $x$ \\
\hline Eggshell & $x$ & & $x$ & & & $x$ & \\
\hline
\end{tabular}


of uranium. Isotopic analyses included ${ }^{234} \mathrm{U},{ }^{235} \mathrm{U}$, and ${ }^{238} \mathrm{U}$ by alpha spectrometry (AS), and for soil samples only $235 U$ and ${ }^{238} U$ by low-energy photon (LEP) analysis. High-resolution mass spectroscopy (MS) was also performed on water samples by PNL to determine isotopic ratios of ${ }^{234} \mathrm{U},{ }^{235} \mathrm{U},{ }^{236} \mathrm{U}$, and ${ }^{238} \mathrm{U}$. The presence of ${ }^{236} \mathrm{U}$ in environmental samples would indicate the presence of Hanford-derived uranium. Uranium-236 is an activation product of $235 \mathrm{U}$ and is not a naturally occurring isotope.

\section{Chemical Anal yses}

Chemical analyses were performed on ground water and lake water only. Analyses were performed to detect trace metals by inductively coupled plasma emission spectroscopy (ICP) ; semivolatile and vol atile organic compounds by gas chromatography-mass spectroscopy (GC-MS) of hexane extracts, organic compounds by GC coupled to flame ionization detector; polychlorinated biphenyls (PCB) with methylene chloride extractions, thiourea compounds, organophosphorus pesticides, other pesticides, and herbicides by GC. 


\section{SAMPLING RESULTS}

Radiochemical analyses were conducted on ground water, lake water, sediment, salt deposits, soil, vegetation, and coot eggshells. A constituent was considered present in the sample if the analytical result was positive and exceeded 2 standard deviations of the counting data. Data were compared to representative control samples and expected isotopic ratios for uranium. Analyses of inorganic constituents were limited to ground water and West Lake surface water, and focused on a number of constituents. West Lake water was also analyzed for organic constituents, and the data are presented by the envi ronmental medium in the appendixes.

\section{GROUND WATER}

Historical analytical results, dating to January 1987, have been summarized with the data from the wells sampled in August 1989. Well 699-59-58, the well nearest West Lake that was sampled, was the only one of the four wells sampled in which radionuclides were detected (see Appendix A, Table A.1). The presence of ${ }^{3} \mathrm{H}$ and ${ }^{99}$ TC provides the strongest link with waste disposal practices in the 200 Areas because these radionuclides tend to move with the flow of ground water.

Techneti um-99 was detected in well 699-59-58 in duplicate August 1989 samples at 53.8 and $55.1 \mathrm{pCi} / \mathrm{L}$. Concentrations of ${ }^{99} \mathrm{TC}$ in the other three wells sampled in August 1989 were below detection limits.

Tritium also was detected in well 699-59-58. The concentrations for the August 1989 samples ranged between 839 and $949 \mathrm{pCi} / \mathrm{L}$ (see Appendix A, Table A.1) and have fluctuated between 442 and $951 \mathrm{pCi} / \mathrm{L}$ between 1987 and 1989. Tritium levels in well 699-60-57 were consistently lower than in well 699-59-58.

Isotopes of uranium, gamma emitters $\left({ }^{60} \mathrm{Co},{ }^{106} \mathrm{Ru}\right.$, and $\left.{ }^{137} \mathrm{Cs}\right)$, and ${ }^{90} \mathrm{Sr}$ were not detected in the wells sampled in August 1989 (see Appendix A, Table A.1). 


\section{LAKE WATER}

Radiochemical analyses of West Lake water indicate elevated levels of ${ }^{3} \mathrm{H},{ }^{90} \mathrm{Sr}$, and ${ }^{99} \mathrm{Tc}$ (Table 7 and see Appendix A, Table A.2). Concentrations of ${ }^{3} \mathrm{H}$ were approximately five times greater than those reported at Priest Rapids Dam on the Columbia River for 1988 (Table 8). Strontium-90 levels were approximately 100 times greater in West Lake water than in Columbia River water measured at Priest Rapids Dam. Levels of ${ }^{106} \mathrm{Ru}$ and ${ }^{137} \mathrm{Cs}$ frequently were below the limits of detection (see Table 7).

Concentrations of uranium in West Lake water ranged from 98 to $179 \mathrm{pCi}$ ${ }^{238} \mathrm{U} / \mathrm{L}$ (see Appendix A, Table A.3). Uranium values for sample 9 were not used for the calculation of isotopic ratios or mean water concentrations because the sample had a large quantity of resuspended sediment that contaminated it during collection. Isotopic analysis by MS did not detect ${ }^{236} U$, which would have suggested a Hanford source for uranium in West Lake. Further analysis of isotopic ratios of ${ }^{234} \mathrm{U} /{ }^{238} \mathrm{U}$ and ${ }^{235} \mathrm{U} /{ }^{238} \mathrm{U}$ (Table 9) indicated that mass ratios for ${ }^{235} \mathrm{U} /{ }^{238} \mathrm{U}$ were not significantly different than a theoretical value of 0.00725 based on MS data. However, the mass ratios calculated from AS data were significantly different than the theoretical ratio $(P<0.10)$. Ratios generated from MS data and calculated from AS data for ${ }^{234} \mathrm{U} /{ }^{238} \mathrm{U}$ were

TABLE 7. Concentrations ( $\mathrm{pC} \mathrm{i} / \mathrm{L}$ ) of Radionuclides in West Lake Water, August 1989

\begin{tabular}{|c|c|c|c|}
\hline I sotope & Mean & S.E. of Mean & Ranqe \\
\hline${ }^{3} H$ & 395 & 30.3 & 255 to 512 \\
\hline${ }^{60} \mathrm{Co}$ & 2.64 & 0.654 & 1.21 to 1.93 \\
\hline${ }^{90} \mathrm{Sr}$ & 1.67 & 0.104 & 1.21 to 1.93 \\
\hline${ }^{99} \mathrm{Tc}$ & 59.7 & 9.69 & 20.9 to 107 \\
\hline${ }^{106} \mathrm{Ru}$ & 1.86 & 16.0 & -56.1 to 79.7 \\
\hline${ }^{137} \mathrm{Cs}$ & 0.964 & 1.24 & -2.28 to 7.03 \\
\hline
\end{tabular}

(a) Nine samples were collected, but sample 9 was deleted because of high sediment content. 
TABLE 8. Concentrations of Radionuclides in Water and Sediment Collected from Priest Rapids Dam, 1986 Through 1989

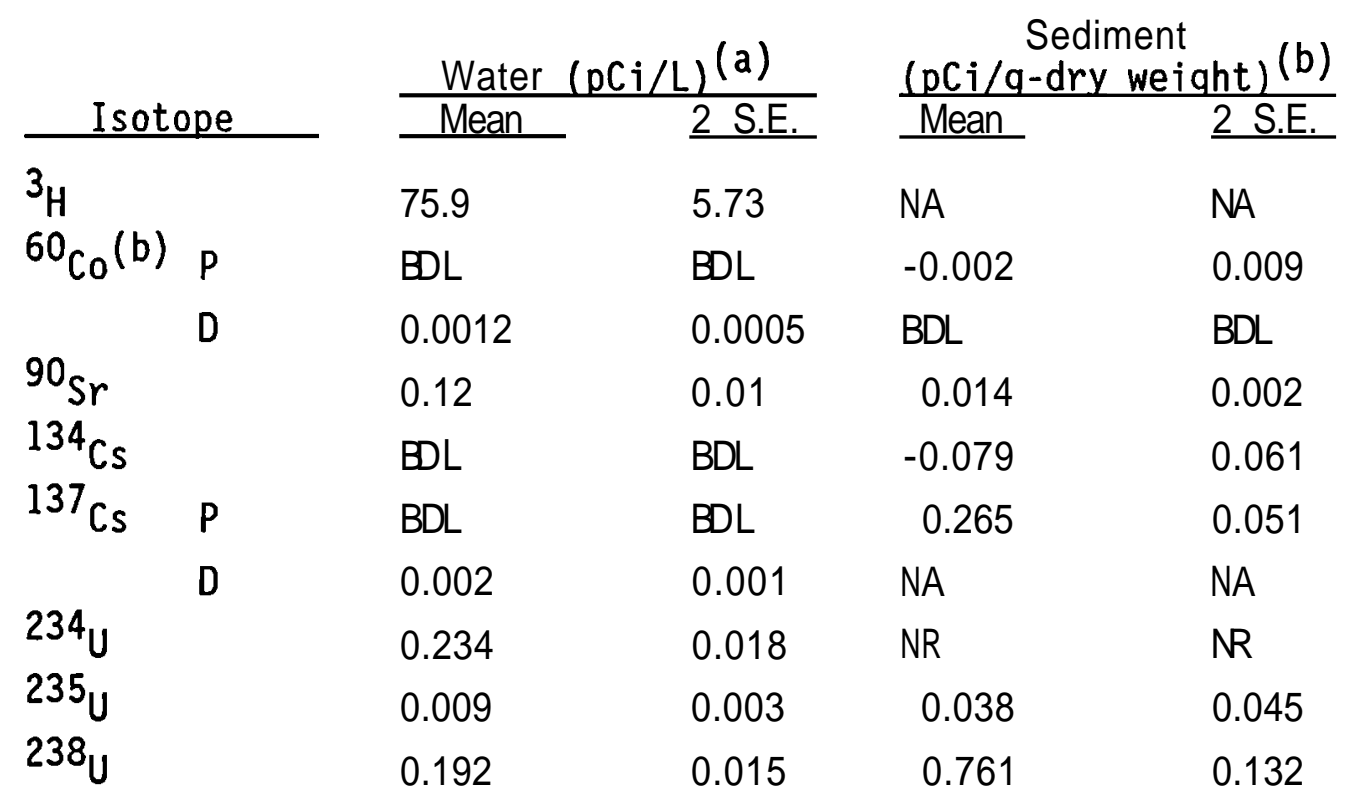

(a) Values are the mean and \pm 2 times the standard error (S.E.) of the mean fror 12 water samples collected from 1986 to 1989 (except ${ }^{60}$ ).

(b) Sediment samples and ${ }^{60}$ Co taken from four samples collected in 1989, as reported by Jaquish and Bryce (1990).

$\mathrm{BDL}=$ Below detection limit.

$\mathrm{D}=$ Dissolved fraction $(\mathrm{t} 0.45 \mu \mathrm{m})$.

$N R=$ Not reported.

$\mathrm{P}=$ Particulate fraction.

TABLE 9. Comparison of Isotopic Ratios of Uranium in West Lake Water, Sediment, and Terrestrial Vegetation

\begin{tabular}{|c|c|c|c|c|c|c|c|}
\hline \multirow[b]{2}{*}{ Medium } & \multirow[b]{2}{*}{ Method } & \multicolumn{3}{|c|}{${ }^{234} U /{ }^{238} U$} & \multicolumn{3}{|c|}{${ }^{235} u / 238 u$} \\
\hline & & Mean & S.D & $\underline{n}(a)$ & Mean & S.D & $\underline{n(a)}$ \\
\hline \multirow{2}{*}{ Lake water } & NS & $5.82 E-5$ & $1.29 \mathrm{E}-6$ & 9 & $7.24 E-3$ & $3.34 \mathrm{E}-5$ & 9 \\
\hline & AS & $5.98 E-5$ & $1.06 \mathrm{E}-6$ & 8 & $6.66 \mathrm{E}-3$ & $8.21 E-4$ & 8 \\
\hline Sediment & AS & $5.14 \mathrm{E}-5$ & $9.52 E-6$ & 9 & $4.87 E-3$ & $1.49 \mathrm{E}-3$ & 9 \\
\hline Vegetation & AS & $6.03 E-5$ & $5.89 \mathrm{E}-6$ & 11 & $4.48 \mathrm{E}-3$ & $2.63 E-3$ & 11 \\
\hline
\end{tabular}

(a) Sample number.

$M S=$ High-resolution mass spectroscopy.

AS = Alpha spectrometry. 
significantly greater $(P<0.001)$ than the theoretical value of $5.5147 E-5$. These observations suggest the possible presence of uranium depleted in the ${ }^{234} U$ and ${ }^{235} U$ isotopes; however, the existing data are inadequate for a definitive conclusion.

\section{SEDIMENT}

Gamma scan results indicated detectable concentrations of ${ }^{40} \mathrm{~K},{ }^{137} \mathrm{Cs}$, ${ }^{212} \mathrm{~Pb}$, and ${ }^{214} \mathrm{~Pb}$ in sediments (Table 10 and see Appendix $\mathrm{A}$, Table A.4). Of these, only ${ }^{137} \mathrm{Cs}$ is of potential Hanford origin, but the concentrations are also within the range of those associated with atmospheric fallout from nuclear weapons testing. The mean radionucl ide concentrations in

TABLE 10. Concentrations ( $p C i / g-d r y)^{(a)}$ of Radionucl ides in Sediment Samples Collected from West Lake

\begin{tabular}{|c|c|c|c|c|c|}
\hline Radionucl ide & Mean & S.E. of Mean & Range & $n^{(b)}$ & $\begin{array}{c}\text { Number of } \\
\text { Samples Above } \\
\text { Detection } \\
\end{array}$ \\
\hline $40_{K}$ & 18.7 & 0.588 & 16.1 to 21.9 & 9 & 9 \\
\hline${ }^{60} \mathrm{CO}_{0}$ & 0.002 & 0.002 & -0.007 to 0.009 & 9 & 0 \\
\hline${ }^{90} \mathrm{Sr}$ & 0.494 & 0.166 & 0.050 to 1.57 & 9 & 0 \\
\hline${ }^{106} \mathrm{Ru}$ & 0.0000222 & 0.027 & -0.096 to 166 & 9 & 1 \\
\hline${ }^{134} \mathrm{Cs}$ & -0.044 & 0.013 & -0.108 to 0.007 & 9 & 0 \\
\hline${ }^{137} \mathrm{Cs}$ & 1.22 & 0.283 & 0.491 to 2.45 & 9 & 9 \\
\hline${ }^{154} \mathrm{Eu}$ & -0.022 & 0.014 & -0.066 to 0.082 & 9 & 1 \\
\hline${ }^{155} \mathrm{Eu}$ & 0.025 & 0.017 & -0.095 to 0.085 & 9 & 1 \\
\hline${ }^{212} \mathrm{~Pb}$ & 0.767 & 0.031 & 0.574 to 0.859 & 9 & 9 \\
\hline${ }^{214} \mathrm{~Pb}$ & 0.594 & 0.027 & 0.49 to 0.743 & 9 & 9 \\
\hline${ }^{234} U$ & 1.54 & 0.314 & 0.213 to 3.29 & 9 & 9 \\
\hline $235 U$ & 0.054 & 0.012 & 0.003 to 0.121 & 9 & 7 \\
\hline $238 U$ & 1.82 & 0.495 & 0.201 to 5.13 & 9 & 9 \\
\hline
\end{tabular}

\footnotetext{
(a) Values reported to three significant figures unless reported otherwise in statistical analysis summary.

(b) Number of samples.
} 
West Lake sediments are higher than those reported for Priest Rapids Dam sediments collected upstream of the Hanford Site (see Table 8).

The concentrations of uranium in West Lake sediments are elevated when compared to background concentrations of uranium typically reported in the surrounding soil type (Price 1988; Poston 1990). Based on AS analysis, concentrations in West Lake sediments ranged from 0.2 to $5.1 \mathrm{pCi}{ }^{238} \mathrm{U} / \mathrm{g}$-dry (see Appendix A, Table A.5). Isotopic mass ratios of ${ }^{234} \mathrm{U} /{ }^{238} \mathrm{U}$ and ${ }^{235} \mathrm{U} /{ }^{238} \mathrm{U}$ were 5.14E-5 and 4.87E-3, respectively (see Table 9). The mass ratio for ${ }^{235} \mathrm{U} /{ }^{238} \mathrm{U}(4.87 \mathrm{E}-3)$, calculated from AS data, was significantly lower than the theoretical value of 7.25E-3 (P (0.01); however, the concentrations of $235 \mathrm{U}$ were close to the AS detection limit, and there were two samples below the detection 1 imit. The ratio of ${ }^{234} \mathrm{U} /{ }^{238} \mathrm{U}$ was $5.14 \mathrm{E}-5$, and was not significantly different than the theoretical val ue of 5.51E-5.

Uranium concentrations in sediment sample 9 contained $1.94 \mathrm{pCi}{ }^{238} \mathrm{U} / \mathrm{g}$ (see Appendix A, Table A.5) ; however, this level of contamination, on its own, does not account for the high level of ${ }^{238} \mathrm{U}$ in water sample $9(5,500 \mathrm{pCi}$ ${ }^{238} \mathrm{U} / \mathrm{L}$; see Appendix A, Table A.3) collected from this northernmost pool.

\section{SALT DEPOSITS}

In close association with sediments are samples of salt deposits collected at the north end of West Lake adjacent to the northernmost pool, where samples designated $\mathbf{L} \mathbf{9}$ were collected. There is an apparent concentration of about a factor of 10 of uranium in these salt deposits compared to sediments (Tables 11 and 12 and see Appendix A, Table A.5) and a factor of 20 to 80 for West Lake basin soils (see Table 10 and Appendix A, Table A.6). Concentrations of ${ }^{40} \mathrm{~K},{ }^{90} \mathrm{Sr}$, and ${ }^{137} \mathrm{Cs}$, in salt deposits were less than those reported in sediment and soil samples.

$\underline{\text { SOIL }}$

Soil samples had detectable concentrations of ${ }^{40} \mathrm{~K},{ }^{90} \mathrm{Sr},{ }^{137} \mathrm{Cs},{ }^{212} \mathrm{~Pb}$, ${ }^{214} \mathrm{~Pb}$, and ${ }^{238} \mathrm{U}$ (see Table 12 and Appendix A, Tables A.6, A.7, and A.8). 
TABLE 11. Concentrations of Radionuclides in Salt Deposits Collected from the North End of the West Lake Basin (value in italics is \pm 2 standard deviations of count data)

\begin{tabular}{|c|c|c|c|c|c|c|}
\hline \multirow{2}{*}{$\begin{array}{l}\text { Sample } \\
\text { weight, q }\end{array}$} & \multicolumn{6}{|c|}{ Radionuclide, $\mathrm{pCi} / \mathrm{a}$} \\
\hline & $40_{K}$ & ${ }^{60} \mathrm{C}_{0}$ & ${ }^{90} \mathrm{Sr}$ & ${ }^{106} \mathrm{Ru}$ & ${ }^{134} \mathrm{Cs}$ & ${ }^{137} C_{s}$ \\
\hline 178 & $\begin{array}{l}5.17 E+00 \\
8.16 E-01\end{array}$ & $\begin{array}{r}-1.71 \mathrm{E}-04 \\
1.86 E-02\end{array}$ & $\begin{array}{l}1.96 \mathrm{E}-02 \\
9.24 E-03\end{array}$ & $\begin{array}{r}-8.10 E-02 \\
1.74 E-01\end{array}$ & $\begin{array}{r}-9.40 \mathrm{E}-03 \\
1.97 \mathrm{E}-02\end{array}$ & $\begin{array}{l}7.09 \mathrm{E}-02 \\
2.44 \mathrm{E}-01\end{array}$ \\
\hline \multirow[t]{2}{*}{703} & $\begin{array}{l}9.44 \mathrm{E}+00 \\
1.08 E+00\end{array}$ & $\begin{array}{l}2.37 \mathrm{E}-03 \\
1.32 E-02\end{array}$ & $\begin{array}{l}1.25 \mathrm{E}-01 \\
2.77 \mathrm{E}-02\end{array}$ & $\begin{array}{r}-1.17 \mathrm{E}-02 \\
1.03 E-01\end{array}$ & $\begin{array}{r}-2.06 \mathrm{E}-02 \\
1.28 \mathrm{E}-02\end{array}$ & $\begin{array}{l}3.20 E-01 \\
4.20 E-02\end{array}$ \\
\hline & \multicolumn{6}{|c|}{ Radionuclide, $\mathrm{pCi} / \mathrm{q}$} \\
\hline 178 & $\begin{array}{l}5.01 \mathrm{E}-02 \\
6.83 E-02\end{array}$ & $\begin{array}{l}1.57 \mathrm{E}-01 \\
4.13 \mathrm{E}-02\end{array}$ & $\begin{array}{l}1.51 \mathrm{E}-01 \\
5.77 \mathrm{E}-02\end{array}$ & $\begin{array}{l}1.74 E+01 \\
1.70 E+00\end{array}$ & $\begin{array}{l}5.68 \mathrm{E}-01 \\
9.15 \mathrm{E}-02\end{array}$ & $\begin{array}{l}1.64 E+01 \\
1.60 E+00\end{array}$ \\
\hline 703 & $\begin{array}{l}3.64 \mathrm{E}-02 \\
3.79 E-02\end{array}$ & $\begin{array}{l}3.68 \mathrm{E}-01 \\
4.58 \mathrm{E}-02\end{array}$ & $\begin{array}{l}2.72 \mathrm{E}-01 \\
4.16 E-02\end{array}$ & $\begin{array}{l}6.61 E+00 \\
7.22 E-01\end{array}$ & $\begin{array}{l}2.47 \mathrm{E}-01 \\
6.35 E-02\end{array}$ & $\begin{array}{l}6.23 E+00 \\
6.83 E-01\end{array}$ \\
\hline
\end{tabular}

Levels of ${ }^{90} \mathrm{Sr}$ and ${ }^{137} \mathrm{Cs}$ exceed background levels reported in Yakima, Washington, for 1989 (Table 13). Concentrations of ${ }^{238} \mathrm{U}$ were slightly higher in soils than for other uncontaminated soils typical of the Hanford Site. Isotopic ratios of uranium were not calculated for soil samples because the LEP method lacks the sensitivity to measure ${ }^{235} U$ and ${ }^{234} U$ at the concentrations found in soil on the Hanford Site (Poston 1990).

\section{VEGETATION}

Vegetation samples had detectable concentrations of ${ }^{40} \mathrm{~K},{ }^{90} \mathrm{Sr},{ }^{137} \mathrm{Cs}$, ${ }^{234} U$, and ${ }^{238} U$ (Table 14 and see Appendix A, Tables A. 9 and A. 10) ; however, concentrations were more variable than those observed in water, soil, and sediment. Mean concentrations of ${ }^{90} \mathrm{Sr}$ and ${ }^{137} \mathrm{Cs}$ were generally higher in vegetation samples collected from the south transect but the differences were not statistically significant $(P=0.05)$. In contrast, mean concentrations of ${ }^{234} U$ and ${ }^{238} U$ were higher in samples collected from the north transect.

Samples collected near the northernmost pool had the highest uranium concentrations of all vegetation samples (see Appendix A, Table A.II). This is 
TABLE 12. Concentrations ( $\mathrm{pCi} / \mathrm{g}-\mathrm{dry})^{(\mathrm{a})}$ of Radionuclides in Soil Samples Collected from the West Lake Basin, August 1989

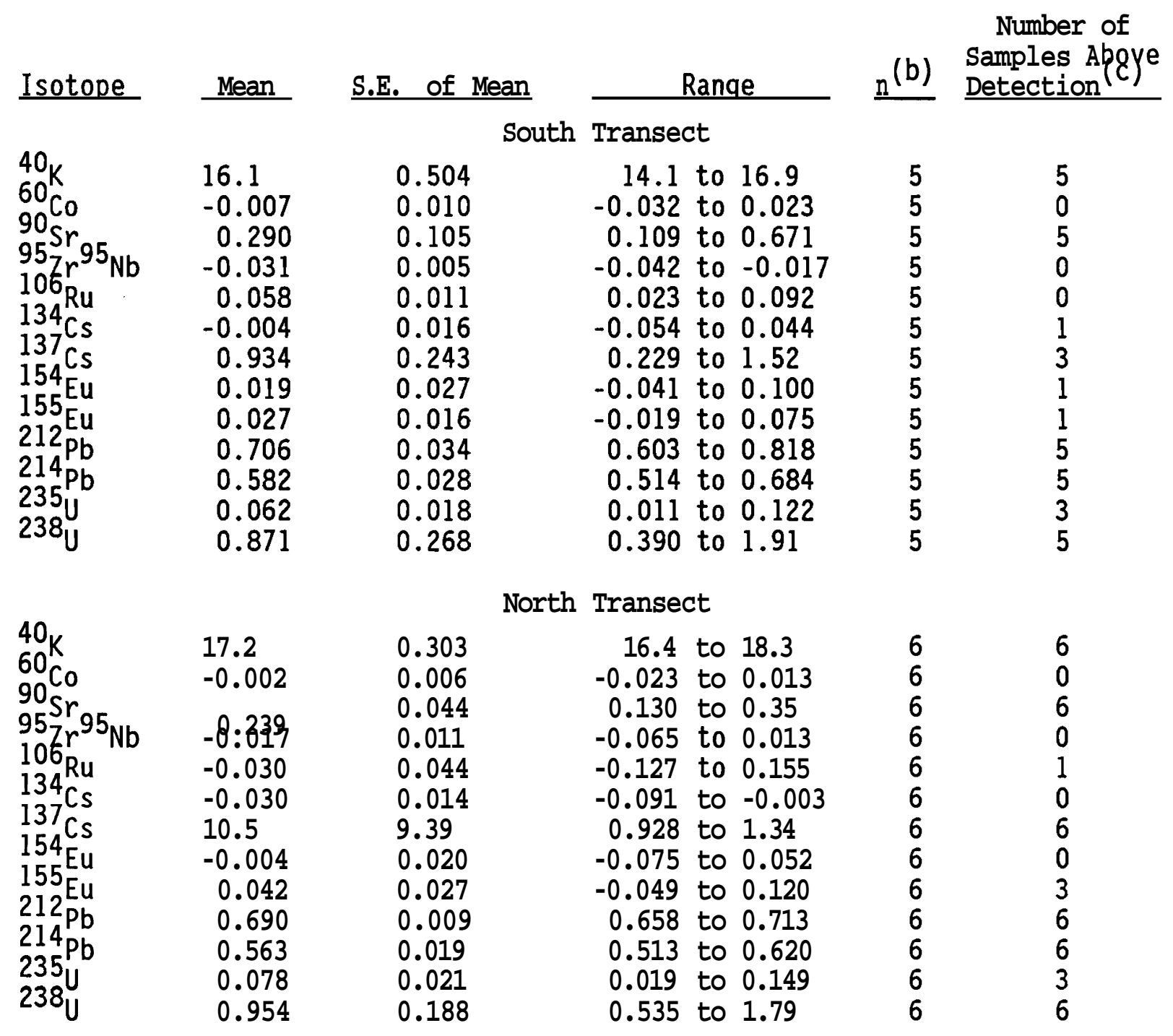

\footnotetext{
(a) Val ues reported to three significant figures unless reported otherwise in the statistical analysis summary.

(b) Number of samples.

(c) Value exceeds \pm 2 standard deviations of count data.
} 
TABLE 13. Concentrations of Radionuclides in Soil and Vegetation Collected Upwind of Hanford at Yakima, Washington, 1986 Through 1989(a)

\begin{tabular}{|c|c|c|c|c|}
\hline \multirow[b]{2}{*}{ I sotope } & \multicolumn{2}{|c|}{ Soil (pCi/q-dry) } & \multicolumn{2}{|c|}{ Vegetation (pCi/q-dry) } \\
\hline & Mean & S.E. & Mean & S.E. \\
\hline${ }^{90} \mathrm{Sr}$ & 0.07 & 0.02 & 0.024 & 0.006 \\
\hline${ }^{137}$ Cs & 0.22 & 0.17 & 0.063 & 0.099 \\
\hline $238 \mathrm{U}$ & 0.64 & 0.42 & $0.023^{(b)}$ & 0.007 \\
\hline
\end{tabular}
(a) Values are the mean and \pm 2 times the standard error of the mean for 38 samples; environmental monitoring (b) 1989 data only.

noteworthy from the standpoint that the water sample collected from this pool and the salt deposits and adjacent soil samples all had high levels of uranium.

\section{@OOT EGGSHELLS}

Detectable concentrations of ${ }^{90} \mathrm{Sr},{ }^{234} \mathrm{U}$, and ${ }^{238} \mathrm{U}$ were found in coot eggshells collected from West Lake and Morgan Lake, a control site. Concentrations of ${ }^{238} \mathrm{U}$ were found to be approximately equal in eggshells from both sites and, in both cases, were only slightly greater than the \pm 2 standard deviations (see Appendix A, Table A.12). Strontium-90, however, was distinctly elevated in eggshells sampled at West Lake, and the concentrations of 4.7 to $5.6 \mathrm{pCi} / \mathrm{g}$ were approximately 50 times greater than the 0.06 to $0.1 \mathrm{pCi} / \mathrm{g}$ found in eggshells from Morgan Lake.

\section{NONRADIOLOGICAL ANALYSES}

\section{Ground Water}

The analyses of cations and anions sampled from four wells during August 1989 are shown in Table 15. The concentrations of calcium and magnesium ions were at or below background in Hanford Site ground water (as reported by Evans 
TABLE 14. Concentrations $(\mathrm{pC} \mathrm{i} / \mathrm{g}-\mathrm{dry})^{(\mathrm{a})}$ of Radionuclides in Vegetation Samples Collected from the West Lake Basin, August 1989

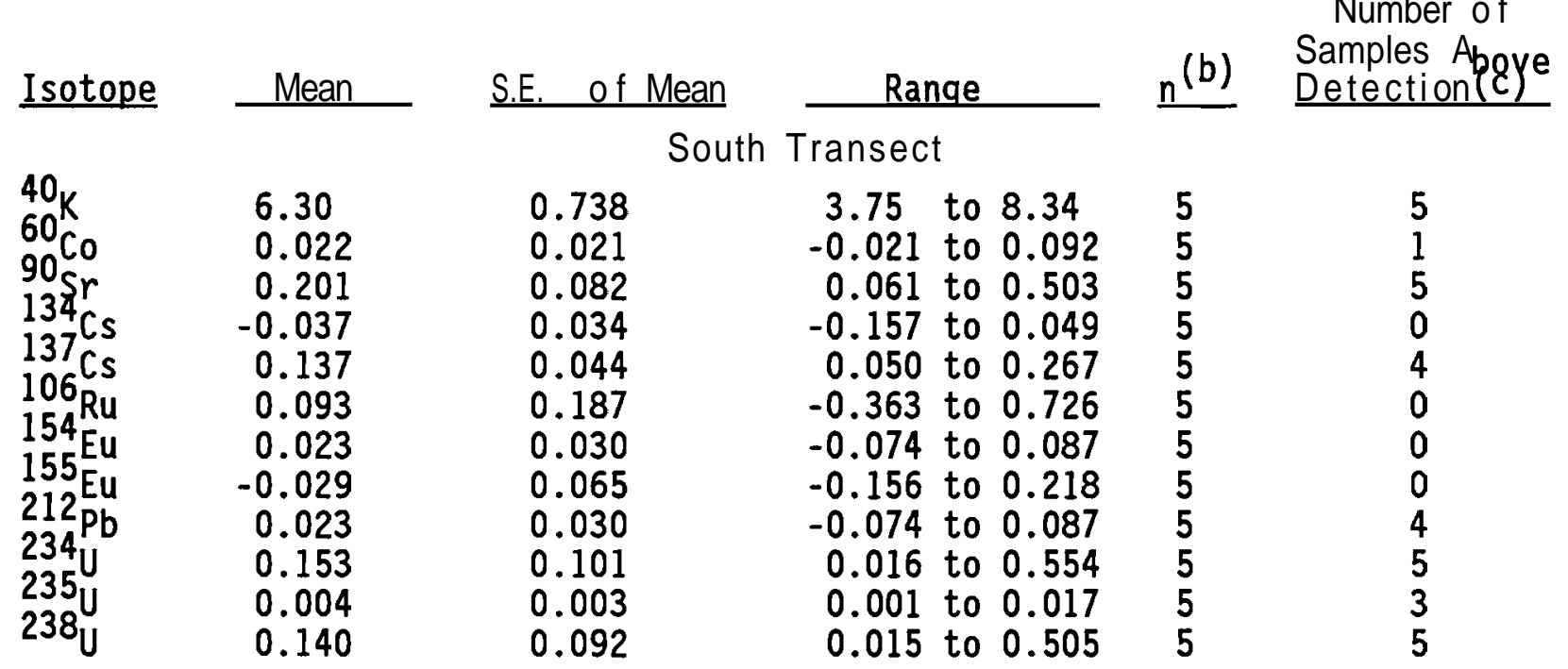

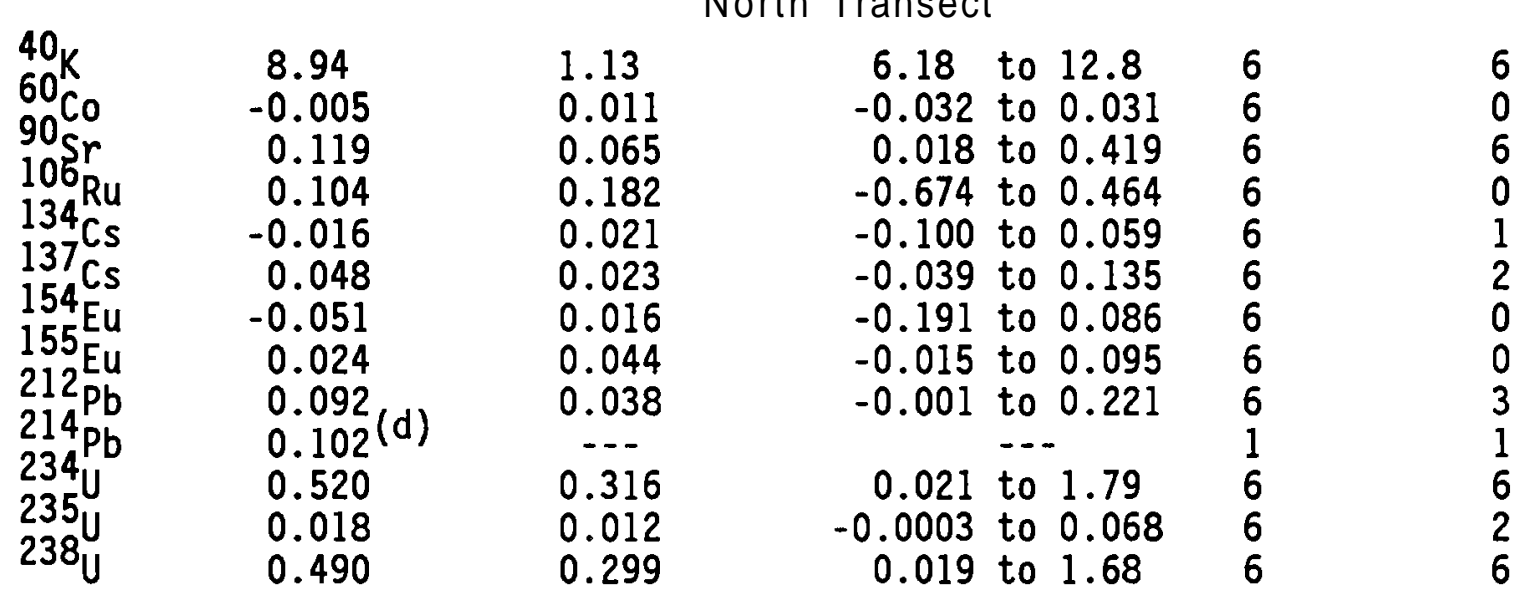

(a) Values reported to three significant figures unless reported otherwise

in the statistical analysis summary.

(b) Number of samples.

(c) Value exceeds \pm 2 standard deviations of count data.

(d) Single value. 
TABLE 15 Concentrations $\mu \mathrm{g} / \mathrm{L}$ ) of Cations and Anions from Selected Wells, August 1989

Sample Calcium Magnesium Sodium Potassium Iron Chloride Sulfate Nitrate Fluoride Phosphate Bromide $\underline{\text { Nitrite }}$ Well 699-53-55A

$\begin{array}{lrrrrrrrrrrr}\text { Unfiltered } & 31,700 & 9,550 & 17,000 & 8,550 & 9,420 & 20,000 & 4,000 & <500 & <500 & <10<1,000<1,000 \\ \text { Filtered } & 26,730 & 8,560 & 14,610 & 7,360 & 3,550 & --- & --- & --- & --- & --- & ---\end{array}$

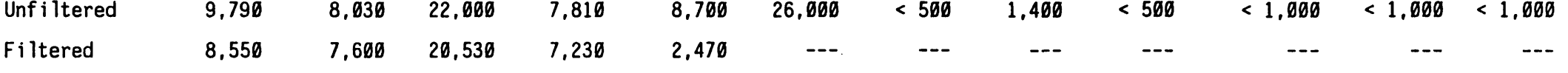

Well 699-59-58

Unfiltered $\quad 19,200 \quad 6,190 \quad 25,500 \quad 4,890 \quad 35,300 \quad 6,200 \quad 18,400 \quad 3,600 \quad 1,100 \quad<1,000<1,000<1,000$

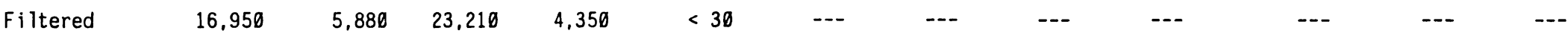

$\stackrel{\omega}{\perp}$

\begin{tabular}{|c|c|c|c|}
\hline Unfiltered & 16,900 & 5,010 & 36,300 \\
\hline Filtered & 16,070 & 5,100 & 35,780 \\
\hline \multirow[t]{4}{*}{ Background $(a)$} & 40,400 & 11.800 & 18,260 \\
\hline & $\pm 10,300$ & \pm 3.406 & $\pm 10,150$ \\
\hline & \multicolumn{3}{|c|}{ Field Measurements } \\
\hline & $\begin{array}{l}\text { Temperature } \\
\left({ }^{\circ} \mathrm{C}\right)\end{array}$ & $\mathrm{pH}$ & $\begin{array}{l}\text { Conduct ivity } \\
\text { (umhos } / \mathrm{cm})\end{array}$ \\
\hline ₹99-53-55A & 7.6 & 7.44 & 320 \\
\hline ₹99-56-53 & 15.5 & 8.07 & 230 \\
\hline «99-59-58 & 16.9 & 7.99 & 253 \\
\hline ₹99-6ø-57 & 18.5 & 8.14 & 278 \\
\hline
\end{tabular}

(a) Background levels taken from Evans et a1. (1989) --- = Less than detection. 
TABLE 16. Concentrations $(\mu \mathrm{g} / \mathrm{L})$ of Trace Metals in Well Water, August 1989

\begin{tabular}{|c|c|c|c|c|c|c|c|c|}
\hline \multirow[b]{2}{*}{ Al umi num } & \multicolumn{2}{|c|}{$\frac{\text { Well } 699-53-55 \mathrm{~A}}{\text { Filtered Unfil. }}$} & \multicolumn{2}{|c|}{$\frac{\text { Wel1 } 699-56-53}{\text { Fi ltered Unfil. }}$} & \multicolumn{2}{|c|}{$\frac{\text { We11 } 699-59-58}{\text { Filtered Unfil. }}$} & \multicolumn{2}{|c|}{$\frac{\text { We11 699-60-57 }}{\text { Filtered Unfil }}$} \\
\hline & $<150$ & $<150$ & $<150$ & $<150$ & $<150$ & $<150$ & $<150$ & $<150$ \\
\hline Antimony & $<100$ & $<100$ & $<100$ & $<100$ & $<100$ & $<100$ & $<100$ & $<100$ \\
\hline Bari um & 42 & 47 & 7 & 7 & 6 & 20 & 12 & 1 \\
\hline Beryl 1 i um & $<5$ & 8 & $<5$ & $<5$ & $<5$ & 7 & $<5$ & \\
\hline Boron & $<10$ & 29 & $<10$ & $<10$ & 22 & 31 & 57 & \\
\hline Cadmium & $<2$ & 3 & $<2$ & 4 & $<2$ & 7 & $<2$ & $<$ \\
\hline Chromi um & $<10$ & $<10$ & $<10$ & $<10$ & $<10$ & 12 & $<10$ & $<10$ \\
\hline Copper & $<10$ & $<10$ & 43 & 36 & $<10$ & 16 & $<10$ & $<1$ \\
\hline Cobalt & t20 & $<20$ & $t 20$ & $<20$ & $<20$ & $<20$ & $<20$ & $<20$ \\
\hline Lithium & $<10$ & $<10$ & $<10$ & $<10$ & $<10$ & $<10$ & $<10$ & $<10$ \\
\hline Manganese & 54 & 70 & 208 & 265 & 58 & 196 & 88 & 114 \\
\hline Molybdenum & $<40$ & $<40$ & $<40$ & $<40$ & $<40$ & $<40$ & $<40$ & $<40$ \\
\hline Nickel & $<10$ & $<10$ & $<10$ & 13 & $<10$ & $<10$ & $<10$ & $<10$ \\
\hline $\operatorname{Tin}$ & $<30$ & $<30$ & $<30$ & $<30$ & $<30$ & $<30$ & $<30$ & $<30$ \\
\hline Titani um & $<60$ & $<60$ & $<60$ & $<60$ & $<60$ & $<60$ & $<60$ & $<60$ \\
\hline Si lver & $<10$ & $<10$ & $<10$ & $<10$ & $<10$ & $<10$ & $<10$ & $<10$ \\
\hline Sil icon & 14,278 & 17,213 & 636 & 954 & 14,904 & 19,715 & 16,371 & 17,977 \\
\hline Stronti um & 240 & 272 & 61 & 68 & 87 & 101 & 81 & 8 \\
\hline Vanadi um & 8 & $<5$ & $<5$ & $<5$ & 6 & 69 & $<5$ & \\
\hline Zinc & 272 & 333 & 97 & 118 & 257 & 1172 & 9 & $225 \varepsilon$ \\
\hline Zi rconi um & $<50$ & $<50$ & $<50$ & $<50$ & $<50$ & $<50$ & $<50$ & \\
\hline
\end{tabular}

\section{West Lake Surface Water}

Trace metals were analyzed for in samples of West Lake water in 1989. of these (Table 17), arsenic, chromium, copper, and zinc exceeded EPA criteria for acute toxicity to fresh-water aquatic organisms (45 FR 79318). The EPA criteria were established to protect aquatic life and are based on numerous toxicity eval uations using fresh-water organisms. However, the levels are probably not toxic to organisms found in West Lake because of the lake's high salt content and alkaline state. Additionally, mercury, was found at concentrations in excess of the chronic toxicity criteria. When compared to trace 
et a1. 1989). The background concentrations for calci um and magnesium ion were $40,400 \pm 10,300$ and $11,800 \pm 3,400 \mu \mathrm{g} / \mathrm{L}$, respectively (Evans et a1. 1989).

Concentrations of sodium and potassium ions were above background for these constituents in some of the wells. The sodium concentration in well 699-60-57 was greater than the background level (see Table 15). The concentrations of potassium in wells 699-53-55A and 699-56-53 were higher than background. The background concentrations of potassium and sodium range between 3,710 and 6,190 and 8,110 and $28,410 \mu \mathrm{g} / \mathrm{L}$, respectively (Evans et al. 1989).

The concentration of sulfate was at or below background: $34,300 \pm 16,900 \mu \mathrm{g} / \mathrm{L}$ for we11s 699-53-55A, 699-59-58, and 699-60-57, and was not detected in well 699-56-53 (see Table 15).

The difference in the concentration between the unfiltered and filtered samples in wells 699-53-55A, 699-56-53, 699-59-58, and 699-60-57 indicates that iron compounds are suspended as particulate matter in these wells. High concentrations of chloride, associated with high concentrations of iron in samples from wells 699-53-55A and 699-56-53, indicate that iron also may be dissolved as an iron chloride complex. These chloride concentrations are higher than the background range of $10,300 \pm 6,500 \mu \mathrm{g} / \mathrm{L}$ (see Table 15). The possibility of this complex is most likely the result of a lack of purging the well during sample collection and is probably not representative of the ground water.

Barium, zinc, manganese, strontium, and silicon were consistently detected in a11 samples (Table 16). Graham et al. (1984) reported that the concentration of barium is probably controlled by the solubility of barite. Calculation of the molar activity of barium, using the solubility product.of barite and the concentration of sulfate from each of the wells, indicated that the sample from well 699-53-55A was saturated with respect to barium and that the samples from the other three wells were below saturation with respect to barium. Most of the remaining trace metals analyzed were near the detection limit. The high concentration of vanadium in an unfiltered water sample from well 699-59-58 was $69 \mu \mathrm{g} / \mathrm{L}$ and may be a result of suspended particulate matter in the sample. 
TABLE 17. Concentrations $(\mu \mathrm{g} / \mathrm{L})$ of Trace Metals in Unfiltered Water Samples Collected from West Lake

\begin{tabular}{|c|c|c|c|}
\hline El ement & $\begin{array}{l}\text { Detect ign } \\
\text { Limit a) }\end{array}$ & $\begin{array}{c}\text { August } 1989 \\
\text { Concentration }\end{array}$ & $\begin{array}{c}\text { Gephart et al. (1976) } \\
\text { Concentration }\end{array}$ \\
\hline Al umi num & 150 & $<150$ & $<20$ \\
\hline Antimony & 100 & $<100$ & $>1,000$ \\
\hline Arsenic & 50 & 900 & NR \\
\hline Barium & 60 & 141 & 830 \\
\hline Beryl 1 ium & 5 & $<5$ & 60 \\
\hline Boron & 100 & 6,156 & 5,000 \\
\hline Cadmium & 2 & $<2$ & $<30$ \\
\hline Chromi um & 100 & 131 & 128 \\
\hline Cobalt & 20 & $<20$ & 20 \\
\hline Copper & 10 & 30 & 355 \\
\hline Cyanide & 10 & $<10$ & NR \\
\hline Iron & 300 & 323 & 360 \\
\hline Lead & 5 & $<5$ & 500 \\
\hline Lithium & 10 & $<10$ & NR \\
\hline Manganese & 500 & 10,749 & 40 \\
\hline Mercury & 0.1 & 0.3 & $<0.2$ \\
\hline Mol y bdenum & 400 & 2,236 & 1,280 \\
\hline Nickel & 10 & $<10$ & 150 \\
\hline Sel en i um & 5 & $<5$ & $N R(b)$ \\
\hline Sil icon & 2,000 & 4,522 & $1,000^{(D)}$ \\
\hline Si lver. & 10 & $<10$ & 40 \\
\hline Stront ium & 100 & 626 & 250 \\
\hline Thall i um & 5 & $<5$ & 3,000 \\
\hline $\operatorname{Tin}$ & 30 & $<30$ & 2,500 \\
\hline Titanium & 60 & $<60$ & NR \\
\hline Vanadi um & 5 & $<5$ & $<100$ \\
\hline Zinc & 50 & 119 & 18,000 \\
\hline Zirconium & 50 & $<50$ & NR \\
\hline
\end{tabular}

\footnotetext{
(a) Detection limit applies to 1989 data only.

(b) Reported as $\mathrm{SiO}_{2}$.

$\mathrm{NR}=$ Not reported.
}

metal levels reported by Gephart et al. (1976), current levels of beryllium, copper, lead, nickel, silver, thallium, tin, and zinc were lower in 1989 than in 1976. There are other inconsistencies in the comparison of the Gephart et al. (1976) data with our results that cannot be addressed because of the scarcity of samples analyzed for each of the two studies. 
The GC and MS analyses of lake water covered a total of 59 organic compounds, 30 pesticides and herbicides, 7 thiourea compounds, and 7 formulations of PCBs (see Appendix B). Of these 103 compounds, only hexachlorophene was reported at a concentration in excess of the $26-\mu \mathrm{g} / \mathrm{L}$ detection limit. On a broader scale, the concentration of total halogenated organic compounds (TOX) was $97 \mu \mathrm{g} / \mathrm{L}$ (minimum detection limit is $20 \mu \mathrm{g} / \mathrm{L}$ ). 


\section{DISCUSSION}

Sampling was conducted in the West Lake basin, its underlying aquifers, and West Lake proper in August 1989. The objective was to further characterize the basin and expand the existing data to further define the degree to which Hanford Site activities have affected the lake. The historical record indicates that West Lake was formed as a permanent lake from contributions of waste water to the underlying aquifer by activities associated with nuclear fuels reprocessing activities in the 200 Areas on the Hanford Site.

While the hypothesis that the lake was formed as a result of aquifer recharge is convincing, profiles of radionuclide and chemical contamination suggest that Hanford activities have only contributed in a minor degree to the radioactive material found in West Lake. Specifically, ${ }^{3} \mathrm{H}$ and ${ }^{99} \mathrm{Tc}$ are found at concentrations in West Lake water that are indicative of a link between a ground-water source and the lake's burden of radioactive material. Pond surface levels are believed to follow fluctuations in the water table, which, in turn, follows fluctuations in water disposal activities.

Historical environmental data on ${ }^{3} \mathrm{H},{ }^{99} \mathrm{Tc},{ }^{129} \mathrm{I}$, uranium isotopes, gross alpha, and gross beta have been collected from samples taken from wells that penetrate the unconfined aquifer. The following are considered tracers for ground-water migration: tritium, as tritiated water $(\mathrm{TOH}) ;{ }^{99} \mathrm{Tc}$; and ${ }^{129} \mathrm{I}$; because they exist as mobile anions with a low propensity for sorption to soil.

Technetium-99 was detected in only one of the four wells sampled in August 1989 (699-59-58); however, other nearby wells have shown significant levels of ${ }^{99}$ Tc between 1987 and 1989 (Figure 8). Concentrations of ${ }^{99} \mathrm{Tc}$ generally increased between 1988 and 1989 in wells 699-59-58 and 699-60-60, both of which are located in the gap between Gable Butte and Gable Mountain west and downgradient of West Lake (see Figure 6). Elevated levels of ${ }^{99} \mathrm{Tc}$ have been detected in other downgradient wells (699-61-62 and 699-64-62, which are open to the unconfined aquifer). The concentration of ${ }^{99} \mathrm{Tc}$ in wells 699-49-55A, 699-49-57, and 699-50-53 upgradient from West Lake fell between 1988 and 1989. These upgradient wells are open also to the unconfined 


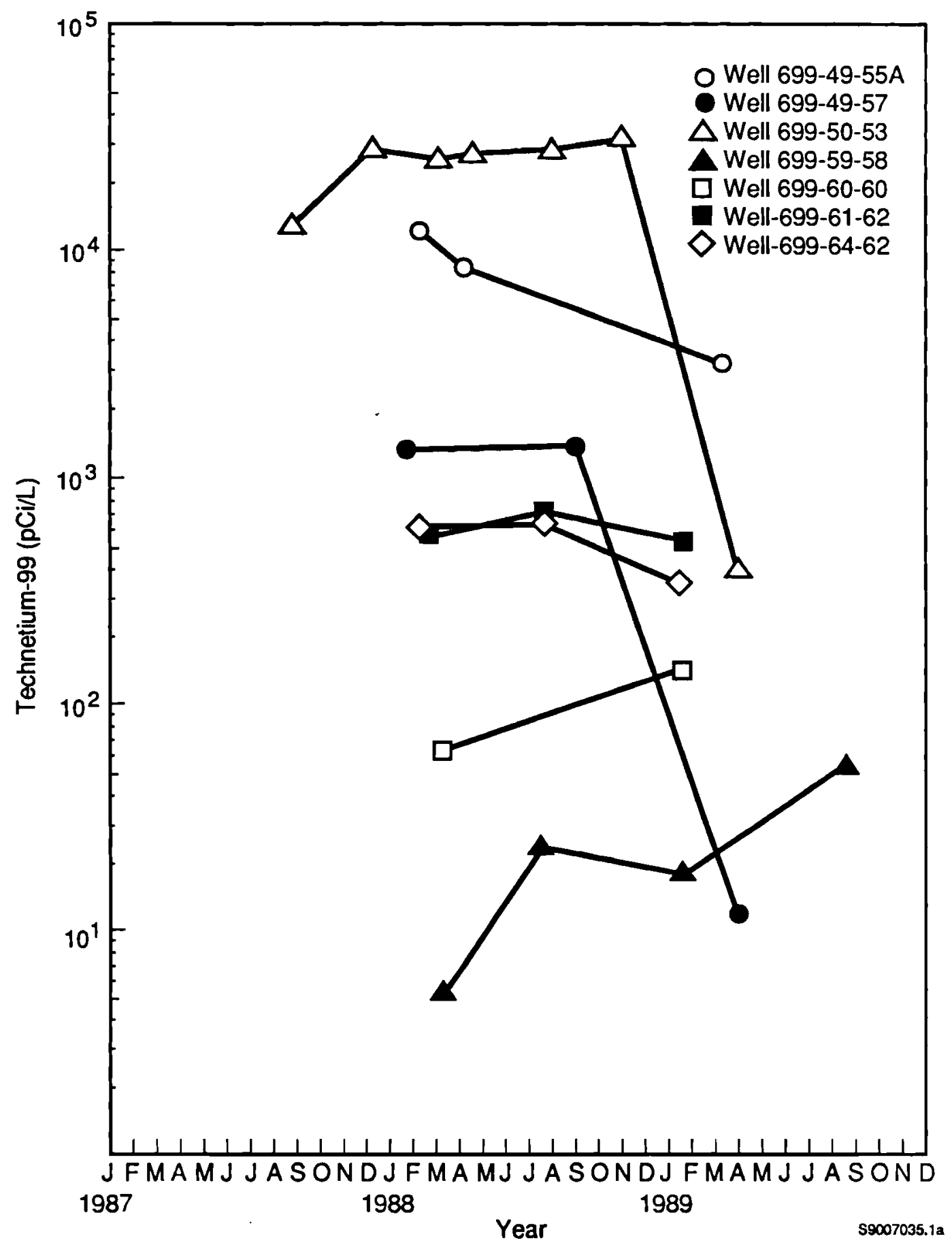

FIGURE 8. Concentrations of ${ }^{99} \mathrm{Tc}$ in Ground-Water Wells Near West Lake, 1987 Through 1989 
Iodine-129 is also considered to be a good tracer of ground water because it is not readily adsorbed by the aquifer materials. Gephart et al. (1976) reported ${ }^{129}$ I concentrations in West Lake that ranged from 0.08 to $0.11 \mathrm{pCi} / \mathrm{L}$ and in upgradient wells $699-53-47$ and $699-55-50 \mathrm{C}$ that ranged from 0.10 to 0.11 and 0.12 to $0.14 \mathrm{pCi} / \mathrm{L}$, respectively. Recent ${ }^{129} \mathrm{I}$ concentration data for wells near West Lake are listed in Table 18 . Concentrations of ${ }^{129} \mathrm{I}$ in the Rattlesnake Ridge confined aquifer in 1982 were 0.000015 and $0.000031 \mathrm{pCi} / \mathrm{L}$ in wells 699-54-57 and 699-56-53, respectively (Graham et al. 1984). The concentration of ${ }^{129} \mathrm{I}$ in the unconfined aquifer (we11 699-55-50C) was $0.052 \mathrm{pCi} / \mathrm{L}$ in 1982 . In this study, ${ }^{129} \mathrm{I}$ was not analyzed for in West Lake. No firm conclusions can be drawn regarding ground-water flow patterns based on ${ }^{129}$ I concentrations because of the existing limited data.

Concentrations of ${ }^{90} \mathrm{Sr}$ in West Lake have remained rather stable, not exceeding $3 \mathrm{pCi} / \mathrm{L}$ since 1985 . The concentrations of ${ }^{90} \mathrm{Sr}$ in two upgradient wells, 699-53-55A and 699-55-50C (see Appendix C, Figure C.2), also are stable; however, the values are lower and generally do not exceed $1 \mathrm{pCi} / \mathrm{L}$. Data for ${ }^{90} \mathrm{Sr}$ concentrations in other wells near West Lake are essentially zero (see Appendix C, Figure C.2). Strontium-90 is not considered to be a good ground-water tracer because it is readily adsorbed by aquifer materials. Although elevated concentrations of ${ }^{235} U$ and $238 U$ are present in West Lake, little data exist for these constituents from wells in the vicinity of

TABLE 18. Concentrations of ${ }^{129}$ I from Wells Near West Lake

\begin{tabular}{|c|c|c|c|}
\hline Well Number & Zone Sampled & Date & Concentration ( $\mathrm{pCi} / \mathrm{L}$ ) \\
\hline $699-49-57$ & Unconfined & $6 / 01 / 88$ & $3.40 E-01$ \\
\hline $699-49-57$ & Unconfi ned & $3 / 27 / 89$ & $6.94 \mathrm{E}-01$ \\
\hline $699-51-63$ & Unconfined & $4 / 19 / 88$ & $<-1.03 E-01$ \\
\hline $699-55-50 \mathrm{C}$ & Unconfined & $6 / 02 / 88$ & $<2.79 \mathrm{E}-02$ \\
\hline $699-59-58$ & Unconfined & $4 / 26 / 88$ & $<3.10 \mathrm{E}-02$ \\
\hline 699-59-58 & Unconfined & $1 / 18 / 89$ & $<5.61 \mathrm{E}-02$ \\
\hline $699-60-60$ & Unconfined & $1 / 18 / 89$ & $<-1.71 E-02$ \\
\hline
\end{tabular}


aquifer. These data suggest a possible ${ }^{99}$ Tc plume moving downgradient of the 200 Areas through the gap between Gable Butte and Gable Mountain. Elevated concentrations of ${ }^{99} \mathrm{Tc}$ in wells near West Lake suggest that ${ }^{99} \mathrm{Tc}$ in the ground water is derived principally from Hanford Site operations because it does not occur naturally. The presence of ${ }^{99} \mathrm{Tc}$ in West Lake also suggests a connection between the ground water and West Lake.

Tritium concentrations in West Lake have declined from approximately $1,000 \mathrm{pCi} / \mathrm{L}$ in 1984 to approximately $400 \mathrm{pCi} / \mathrm{L}$ in 1988 . The ${ }^{3} \mathrm{H}$ concentration abruptly rose to approximately $700 \mathrm{pCi} / \mathrm{L}$ in the latter part of 1988. Tritium concentrations for unconfined aquifer wells 699-49-57, 699-55-50C, 699-59-58, and 699-60-57 indicate general downward trends since the early to mid-1970s (see Appendix C, Figure C.1). The concentrations in we11 699-49-57 decreased from approximately 400,000 pCi/L in 1975 to approximately $1,500 \mathrm{pCi} / \mathrm{L}$ by 1989 . Trends in ${ }^{3} \mathrm{H}$ concentrations in well 699-49-57 parallel those observed in West Lake between 1984 and 1989 with a delay of approximately one year. This indicates that a possible source of ${ }^{\mathbf{3}_{\mathbf{H}}}$ in West Lake may be the 200 Areas separations facilities, and that the travel time of movement from well 699-49-57 to West Lake is approximately one year. More data, however, are needed to support this hypothesis.

Other possible sources of ${ }^{3} \mathrm{H}$ in West Lake as a result of ground-water migration include Gable Mountain Pond (decommissioned in 1987 and no longer in existence; see Figure 4), BY Crib in the 200 East Area, and B Reactor along the Hanford Site's northern boundary (Gephart et al. 1976). Gable Mountain Pond received waste water that contained very low levels of contamination; consequent1y, ${ }^{3} \mathrm{H}$ contamination of the underlying unconfined aquifer has been minimal (Graham et al. 1984). The ${ }^{3} \mathrm{H}$ concentration in well 699-55-50C, located near Gable Mountain Pond, has generally been lower than 1,500 pCi/L since 1975 (see Appendix C, Figure C.I). Because of changes in ground-water flow direction since Gable Mountain Pond was deactivated, a possible source of ${ }^{3} \mathrm{H}$ may be from ground water beneath $\mathrm{B}$ Pond. Recent data indicate that ${ }^{3} \mathrm{H}$ concentrations beneath $B$ Pond are as high as $79,500 \mathrm{pCi} / \mathrm{L}$ (Smith et a1. 1989). 
the lake. Data from wells 699-59-58 and 699-60-57 indicate uranium concentrations of less than $1 \mathrm{pCi} / \mathrm{L}$ for 1988 and 1989. The concentration of uranium in West Lake was reported to have been $526 \mathrm{mg} / \mathrm{L}$ (Gephart et al. 1976). Conversion of West Lake uranium activity data to a gravimetric value indicates a concentration range of 295 to $542 \mu \mathrm{g} / \mathrm{L}$ (excludes the sample from station L9). 1. An uncertainty exists about the difference between the 1976 value and those for the August 1989 samples.

Another observation regarding the distribution of uranium in West Lake involves the interpretation of the high concentrations of uranium in water reported from station $\mathbf{L} 9$. The $\mathbf{L} 9$ sample was equivalent to $16.5 \mathrm{mg} / \mathrm{L}$, approximately 30 to 56 times greater than water samples collected from other areas of the pond. Moreover, uranium concentrations in soil (see Appendix A, Table A.6) and vegetation (see Appendix A, Table A.11) samples collected from station N6, closest to the. L9 pool, also tended to have the highest concentrations of uranium isotopes compared to other samples collected in August 1989. The sediment sample collected from the $\mathbf{L} 9$ pool did not contain uranium in excess of the range of sediment uranium levels from the other eight sample stations in the lake (see Appendix A, Table A.5). These observations suggest that the area around the northern tip of West Lake contains higher concentrations of uranium than other areas in the lake and basin.

Isotopic analysis of water samples by MS did not detect ${ }^{236} \mathrm{U}$. The presence of ${ }^{236} \mathrm{U}$ in West Lake water would indicate a uranium contribution from fuel reprocessing activities. Additionally, altered ratios of ${ }^{235} U$ to ${ }^{238} U$ would indicate either depleted or enriched uranium. Only water and sediment samples had reproducible values of ${ }^{235} \mathrm{U}$, and in both cases, the ${ }^{235} \mathrm{U} /{ }^{238} \mathrm{U}$ mass ratios were less than the theoretical value calculated from AS data, but the ratios were not statistically different $(P<0.05)$. Mass ratios of ${ }^{234} U /{ }^{238} U$ were, for all analyses, significantly greater than the expected theoretical ratios. Collectively, these test results suggest that the isotopic distribution of uranium in the West Lake basin indicates the presence of depleted uranium; however, this analysis is hampered somewhat by the small number of samples involved and by the fact that, for vegetation and soil samples, the 
levels of ${ }^{235} \mathrm{U}$ are very close to detection limits (see Appendix A, Tables A-6 and $A-11)$. This compromises the interpretation of isotopic mass ratios calculated from AS data.

Historically, alpha and beta concentrations in West Lake have fluctuated. Water samples from West Lake for 1979 indicated an annual average total alpha activity of $\angle 500 \mathrm{pCi} / \mathrm{L}$ and a monthly maximum of $1,100 \mathrm{pCi} / \mathrm{L}$, and an annual average total beta activity of $300 \mathrm{pCi} / \mathrm{L}$ and a monthly maximum of $1,900 \mathrm{pCi} / \mathrm{L}$ (Strait and Moore 1982; also see Appendix C, Figures C.3 and C.4). Emery and McShane (1978) reported comparable beta activity for 1975 through 1976; however, combined filterable $(0.45 \mu \mathrm{m})$ and particulate alpha were lower than the 1979 data. Between 1973 and 1980, high concentrations of gross beta were found in well 699-49-57, located south of West Lake near the 200 East Area. Since 1984, concentrations of gross alpha and gross beta in West Lake (see Appendix C, Figure C.5) have been approximately one order of magnitude greater than concentrations for those constituents detected in nearby we11s. It is believed that the gross alpha and gross beta in West Lake are the result of high concentrations of naturally occurring uranium (Jaquish and Mitchell 1988).

The presence of nitrate (as $\mathrm{NO}_{3}^{-}$) in West Lake provides another possible link with ground water. Concentrations of $N$ in West Lake water $(0.25$ to $<5 \mathrm{mg} / \mathrm{L}$; see Table 1) are approximately a factor of 10 to 25 lower than values reported in ground water (see Appendix C, Figure C.6) but are considered high for natural lakes (Wetzel 1975). Elevated levels of $\mathrm{NO}_{3}^{-}$have been attributed to unsubstantiated reports of past dumping of sewage in the basin (Emery and McShane 1978; Meinhardt and Frostenson 1979). However, it does not appear that the authors considered the contribution of ground-water to lake-water $\mathrm{NO}_{3}^{-}$ concentrations. Elevated levels of $\mathrm{NO}_{3}^{-}$have been reported in well 699-49-57, located approximately $2.8 \mathrm{~km}$ south of West Lake. The $\mathrm{NO}_{3}^{-}$concentrations in the lake are probably lower than for ground water sampled from the unconfined aquifer because of assimilation by phytoplankton and algae and subsequent denitrification to $\mathbf{N}_{2}$. Nitrogen would be given up to the atmosphere because of the shallow depth of the lake, high summer insolation, water stagnation, and high surface-to-volume ratio of 2.5 (Emery and McShane 1978). It should 
be noted that phosphate $\left(\mathrm{PO}_{4}-\mathrm{P}\right)$ falls below the detection 1 imit of $1,000 \mu \mathrm{g} / \mathrm{L}$ in ground water, but was two times that concentration in West Lake water in 1976 and almost ten times that level in 1989 (see Table 1). This observation indicates an increase in $\mathrm{PO}_{4}-\mathrm{P}$ concentrations in West Lake, but the data are insufficient to indicate historical dumping of sewage sludge in West Lake. 


\section{CONCLUSIONS}

West Lake contains slightly elevated levels of several radionucl ides generally associated with Hanford Site activities, worldwide weapons testing fallout, and natural sources. Concentrations of trace metals are elevated, but it is not clear if they are the result of Hanford Site activities or are simply the naturally elevated concentrations found in conjunction with the highly saline character of the basin. The data suggest a minor level of radioactive contamination for certain radionucl ides (i .e., ${ }^{3} \mathrm{H},{ }^{99} \mathrm{Tc}$, and ${ }^{129} \mathrm{I}$ ) attributable to Hanford Site activities; however, the levels of basin contamination are low and are below action levels specified in waste management plans for sites contaminated by radioactivity (WHC 1988). West Lake and its surrounding saline basin is a unique habitat that offers an opportunity to conduct basic ecological research. Studies could be designed to investigate nutrient requirements and cycling in the rare and complex chemical environment of the basin for both rooted emergent vegetation, phytoplankton, attached algae, and terrestrial plant communities. 


\section{REFERENCES}

45 丹 79318-79. November 28, 1980. U.S. Environmental Protection Agency. "Water Quality Criteria Documents; Availability." Federal Register.

Anderson, G. C. 1958. "Seasonal Characteristics of Two Saline Lakes in Washington." Limnology and Oceanography 3(1):51-68.

Castenholz, R. W. 1960. "Seasonal Changes in the Attached Algae of Freshwater and Saline Lakes in the Lower Grand Coulee, Washington." Limnology and Oceanography $5(1): 1-28$.

Cushing, C. E., ed. 1989. Hanford Site National Environmental Policy Act (NEPA) Characterization. PNL-6415, Rev. 2, Pacific Northwest Laboratory, Richland, Washington.

Early, T. O., S. H. Hall, and V. G. Johnson. 1988. "Tritium, Carbon-14, and lodine-129 as Indicators for Localized Vertical Recharge Along an Anticline in the Columbia River Basalts Using a Decay-Corrected Mixing Model." In

Proceedings of the Ground Water Geochemistry Conference, February 16-18, 1988, Denver, Colorado, National Water We11 Association, Dublin, Ohio, pp. 597-620.

Edmondson, W. T., and G. C. Anderson. 1965. "Some Features of Saline Lakes in Central Washington." Limnology and Oceanography 10 Supp:R87-R96.

Emery, R. M., and M. C. McShane. 1978. Comparative Ecology of Nuclear Waste Ponds and Streams on the Hanford Site. PNL-2499, Pacific Northwest Laboratory, Richland, Washington.

EPA. 1986. Resource Conservation and Recovery Act Ground-Water Monitoring Technical Enforcement Guidance Document. CSNR Directive 9950.1, Office of Solid Waste and Emergency Response, U.S. Environmental Protection Agency, Washington, D.C.

ERDA 1975. Finai Environmental Statement, Waste Management Operations, Hanford Reservation, Richland, Washington. ERDA-1538, Vol. 2, U.S. Energy Research and Development Administration, Richland, Washington.

Evans, J. C., R. W. Bryce, D. R. Sherwood, M. L. Kemner, and D. R. Newcomer. 1989. Hanford Site Ground-Water Monitoring for Ju7y Through December 1988. PNL-7120, Pacific Northwest Laboratory, Richland, Washington.

Fitzner R. E., and K. R. Price. 1973. The Use of Hanford Waste Ponds by Waterfowl and Other Birds. BNWL-1738, Pacific Northwest Laboratory, Richland, Washington.

Fitzner R. E., and W. H. Rickard. 1975. Avifauna of Waste Ponds, ERDA Hanford Reservation, Benton County, Washington. BNWL-1885, Pacific Northwest Laboratory, Richland, Washington. 
Gephart, R. E., P. A. Eddy, R. C. Arnett, and G. A. Robinson. 1976. Geohydrologic Study of the West Lake Basin. ARH-CD-775, Atlantic Richfield Hanford Company, Richland, Washington.

Graham, M. J., G. V. Last, and K. R. Fecht. 1984. An Assessment of Aquifer Intercommunication in the $B$ Pond-Gable Mountain Pond Area of the Hanford Site. RHO-RE-ST-12 P, Rockwell Hanford Operations, Richland, Washington.

Hajek, B. F. 1966. Soil Survey, Hanford Project in Benton County, Washington. BNWL-243, Pacific Northwest Laboratory, Richland, Washington.

Jaquish, R. E., and R. W. Bryce, eds. 1990. Hanford Site Environmental Report for Calendar Year 1989. PNL-7346, Pacific Northwest Laboratory, Richland, Washington.

Jaquish, R. E., and P. J. Mitchell. 1988. Environmental Monitoring at Hanford for 1987. PNL-6464, Pacific Northwest Laboratory, Richland, Washington.

Jenkins, 0. P. 1922. "Of the Region About White Bluffs and Hanford." Underground Water Supply, Bulletin No. 26, Division of Geology, State of Washington, Olympia, Washington.

Kasza, G. L., and A L. Schatz. 1989. Groundwater Maps of the Hanford Site Separations Area, January 1989. WHC-EP-0142-2, Westinghouse Hanford Company, Richland, Washington.

Ledgerwood, R. K., and R. A. Deju. 1976. Hydrogeology of the Uppermost Confined Aquifers Underlying the Hanford Reservation. ARH-SA-253, Atlantic Richfield Hanford Company, Richland, Washington.

McGhan, V. L. 1989. Hanford Wells. PNL-6907, Pacific Northwest Laboratory, Richland, Washington.

Meinhardt, C. C., and J. C. Frostenson. 1979. Current Status of 200 Area Ponds. RHO-CD-798, Rockwell Hanford Operations, Richland, Washington.

PNL. 1989. Procedures for Ground-Water Investigations. PNL-6894, Pacific Northwest Laboratory, Richland, Washington.

Poston, T. M. 1990. A Survey for Elevated Levels of Uranium North of the 300 Area on the Hanford Site. PNL-7271, Pacific Northwest Laboratory, Richland, Washington.

Price, K. R. 1988. A Review of Historical Data on the Radionuclide Content of Soil Samples Collected from the Hanford Site and Vicinity. PNL-6734, Pacific Northwest Laboratory, Richland, Washington. 
Riley, R. G., R. M. Bean, R. E. Fitzner, D. A. Neitzel, and W. H. Rickard. 1986. A Preliminary Survey of Polychlorinated Biphenyls (PCBs) in Aquatic Habitats and Great Blue Herons on the Hanford Site. PNL-5685, Pacific Northwest Laboratory, Richland, Washington.

Rogers, L. E., and W. H. Rickard. 1977. Ecology of the 200 Area Plateau Waste Management Environs: A Status Report. PNL-2253, Pacific Northwest Laboratory, Richland, Washington.

Smith, R. M., D. J. Bates, and R. E. Lundgren. 1989. RCRA Ground-Water Monitoring Projects for Hanford Facilities: Progress Report for the Period July 1 to September 30, 1989. PNL-7222, Vol. 1, Pacific Northwest Laboratory, Richland, Washington.

Strait, S. R., and B. A. Moore. 1982. Geohydrology of the Rattlesnake Ridge Interbed in the Gable Mountain Pond Area. RHO-ST-38, Rockwel1 Hanford Operations, Richland, Washington.

Wetzel, R. G. 1975. Limnology. W. B. Saunders Company, Philadelphia, Pennsylvania.

WHC 1988. Environmental Compliance Manua7. WHC-CM-7-5, Westinghouse Hanford Company, Richland, Washington. 


\section{APPENDIX A}

CONCENTRATIONS OF RADIONUCLIDES IN ENVIRONMENTAL MEDIA COLLECTED FROM THE WEST LAKE BASIN 


\section{APPENDIX A}

\section{CONCENTRATIONS OF RADIONUCLIDES IN ENVIRONMENTAL MEDIA COLECTED ROM THE WEST LAKE BASIN}

This appendix contains data taken from analytical reports provided by United States Testing Company, Inc. of selected radionuclides in environmental media collected from the West Lake basin in August 1989 (Tables A. 1 through A. 12). The environmental media include ground water, surface water, sediment, soil, vegetation, and coot eggshells.

The data include the value of the count and two standard deviations of the count data. Data have been taken directly from the reports, and the following considerations apply to their evaluation. Individual values for samples are considered significant (i.e., above the limits of detection) when the value is positive and exceeds two standard deviations of the count data. The data were originally reported in scientific notation to three figures; however, three figures are reported here when the value is at least $0.100 \mathrm{pCi} / \mathrm{g}$ or $\mathrm{pCi} / \mathrm{L}$ for a specific radionuclide. Values less than $0.001 \mathrm{pCi} / \mathrm{g}$ or $\mathrm{pCi} / \mathrm{L}$ are reported as 0.000 .

Minimum detectable concentrations for specific radionuclides have been reported in Jaquish and Bryce (1990) and are summarized in Table A. 13.

\section{REFERENCE}

Jaquish, R. E., and R. W. Bryce, eds. 1990. Hanford Site Environmental Report for Calendar Year 1989. PNL-7346, Pacific Northwest Laboratory, Richland, Washington. 
TABLE A.1 Concentrations $(p C i / L)$ of Radionuclides in Ground-Water Monitoring Wells Near Wes Lake

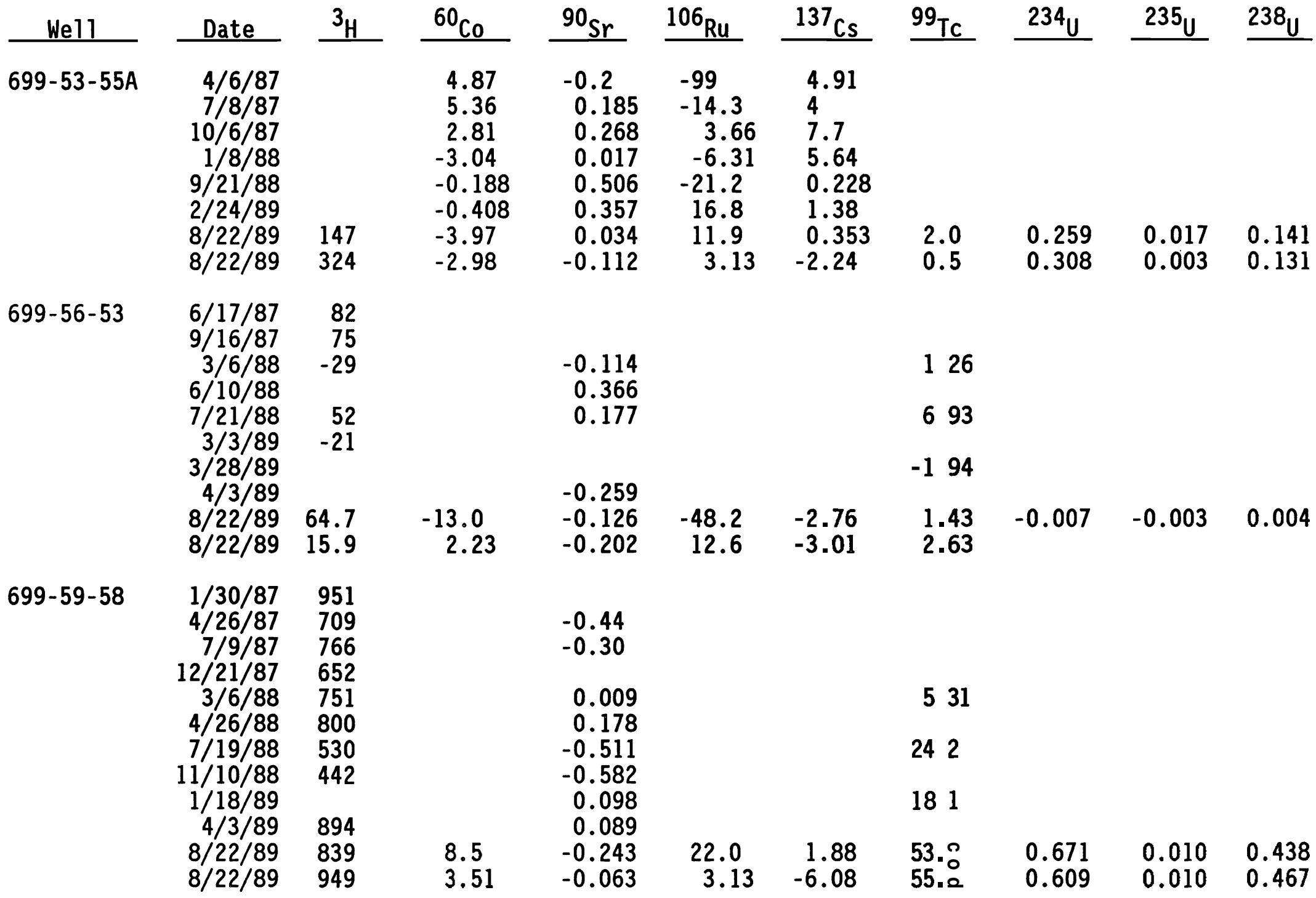




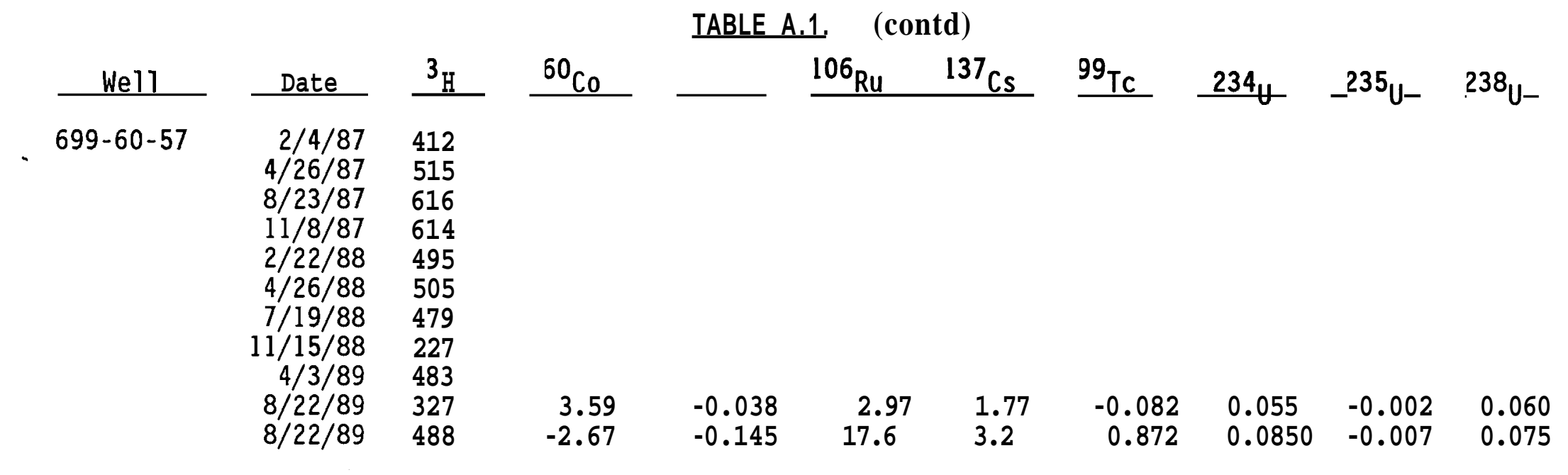

NOTE: Blanks indicate no analysis. 
TABLE A.2. Concentrations ( $\mathrm{pC} \mathrm{C} / \mathrm{L}$ ) of Beta-Emitting Radionuclides in Water Collected from West Lake and Adjacent Pools

\begin{tabular}{|c|c|c|c|c|c|c|c|c|}
\hline $\begin{array}{l}\text { Sample e } \\
\text { Site }\end{array}$ & $\underline{3_{H}}$ & $\begin{array}{l} \pm 2 \text { Standard } \\
\text { Deviations }\end{array}$ & ${ }^{90} s r$ & $\begin{array}{l} \pm 2 \text { Standard } \\
\text { Deviations }\end{array}$ & ${ }^{99} \mathrm{Tc}$ & $\begin{array}{l} \pm 2 \text { Standard } \\
\text { Deviations }\end{array}$ & ${ }^{106} \mathrm{Ru}$ & $\begin{array}{l} \pm 2 \text { Standard } \\
\text { Deviations }\end{array}$ \\
\hline L1 & 449 & 247 & 1.91 & 0.551 & 70.8 & 12.9 & -56.1 & 73.1 \\
\hline L2 & 468 & 249 & 1.93 & 0.552 & 52.0 & 11.3 & 16.7 & 63.6 \\
\hline L3 & 303 & 239 & 1.92 & 0.562 & 86.9 & 14.7 & 16.7 & 72.7 \\
\hline L4 & 512 & 251 & 1.85 & 0.538 & 48.4 & 10.9 & 79.7 & 73.1 \\
\hline L5 & 419 & 246 & 1.77 & 0.627 & 10.7 & 17.0 & 28.2 & 68.5 \\
\hline L6 & 386 & 244 & 1.38 & 0.546 & 53.9 & 11.3 & -46.9 & 85.5 \\
\hline L7 & 255 & 237 & 1.21 & 0.497 & 41.4 & 98.6 & 10.6 & 75.5 \\
\hline L8 & 366 & 242 & 1.39 & 0.525 & 20.9 & 81.6 & -34.0 & 77.8 \\
\hline L9 & 287 & 137 & 1.27 & 2.78 & 11.7 & 18.0 & 2.72 & 83.0 \\
\hline
\end{tabular}


TABLE A.3. Concentrations ( $\mathrm{pC} i / \mathrm{L}$ ) of Uranium Isotopes in West Lake Water

\begin{tabular}{|c|c|c|c|c|c|c|}
\hline $\begin{array}{l}\text { Sample } \\
\text { Site } \\
\end{array}$ & ${ }^{234} U$ & $\begin{array}{l}\text { \#2 Standard } \\
\text { Deviations }\end{array}$ & ${ }_{-}^{235} U_{-}$ & $\begin{array}{l}\text { \#2 Standard } \\
\text { Deviations }\end{array}$ & ${ }^{238} U$ & $\begin{array}{l}\text { \#2 Standard } \\
\text { Deviations }\end{array}$ \\
\hline L1 & 167 & 16.7 & 5.74 & 0.921 & 157 & 15.6 \\
\hline L2 & 191 & 19.6 & 9.56 & 1.43 & 179 & 18.4 \\
\hline L3 & 184 & 18.2 & 7.37 & 1.08 & 167 & 16.6 \\
\hline L4 & 157 & 15.5 & 5.56 & 0.874 & 146 & 14.4 \\
\hline L5 & 176 & 17.8 & 6.62 & 1.05 & 157 & 15.9 \\
\hline L6 & 107 & 10.7 & 4.18 & 0.728 & 977 & 9.83 \\
\hline L7 & 160 & 15.8 & 6.17 & 0.949 & 146 & 14.5 \\
\hline L8 & 184 & 19.0 & 6.56 & 1.12 & 169 & 17.6 \\
\hline $\operatorname{Lg}(a)$ & 5,630 & 488 & 376 & 37.8 & 5,500 & 488 \\
\hline
\end{tabular}

(a) Sample contained large amounts of suspended sediment. 
TABLE A.4. Concentrations ( $\mathrm{pC} / \mathrm{g}$ ) of Radionuclides in Sediments Collected from West Lake

\begin{tabular}{|c|c|c|c|c|c|c|c|c|c|c|c|c|}
\hline $\begin{array}{l}\text { Sample } \\
\text { Site } \\
\end{array}$ & $4 \emptyset_{K}$ & $\begin{array}{l} \pm 2 \text { Standard } \\
\text { Deviations }\end{array}$ & ${ }^{60} \theta_{\mathrm{Co}}$ & $\begin{array}{l} \pm 2 \text { Standard } \\
\text { Deviations }\end{array}$ & $9 \theta_{S r}$ & $\begin{array}{l} \pm 2 \text { Standard } \\
\text { Deviations }\end{array}$ & ${ }^{95} \mathrm{Zr}^{95} \mathrm{Nb}$ & $\begin{array}{l} \pm 2 \text { Standard } \\
\text { Deviations }\end{array}$ & ${ }^{106} \mathrm{Ru}$ & $\begin{array}{l} \pm 2 \text { Standard } \\
\text { Deviations }\end{array}$ & ${ }^{134} \mathrm{Cs}$ & $\begin{array}{l}\text { 土2 Standa } \\
\text { Deviation: }\end{array}$ \\
\hline L1 & 16.1 & 1.8 & 0.009 & 0.017 & 0.829 & 0.164 & -0.033 & 0.047 & -0.056 & 0.169 & -0.048 & 0.020 \\
\hline L2 & 20.4 & 2.22 & 0.009 & 0.018 & 0.873 & 0.165 & 0.097 & 0.043 & -0.096 & 0.168 & -0.068 & 0.023 \\
\hline L3 & 17.9 & 1.96 & 0.003 & 0.018 & ø. 258 & 0.051 & -0.008 & 0.039 & 0.038 & 0.153 & -0.043 & 0.018 \\
\hline L4 & 17.8 & 1.98 & 0.004 & 0.023 & 1.570 & 0.304 & -0.046 & 0.048 & 0.655 & 0.171 & -0.025 & 0.020 \\
\hline L5 & 18.9 & 2.09 & -0.003 & 0.02 & b 144 & 0.030 & -0.019 & 0.047 & 0.623 & 0.150 & 0.007 & 0.015 \\
\hline L6 & 18.1 & 2.04 & 0.001 & 0.022 & 0050 & 0.012 & -0.030 & 0.049 & -0.017 & 0.177 & -0.009 & 0.016 \\
\hline L7 & 17.5 & 1.91 & 0.001 & 0.014 & 0220 & 0.642 & -0.016 & 0.036 & -0.054 & 0.126 & -0.009 & 0.913 \\
\hline L8 & 21.9 & 2.42 & 0.003 & 0.023 & 0239 & 0.047 & 0.031 & 0.057 & -0.060 & 0.177 & -0.108 & 0.026 \\
\hline L9 & 20.0 & 2.19 & -0.007 & 0.821 & D266 & 0.051 & -0.032 & 0.052 & 0.166 & 0.161 & -0.089 & 0.022 \\
\hline $\begin{array}{l}\text { Sample } \\
\text { Site } \\
\end{array}$ & ${ }^{137} C_{s}$ & $\begin{array}{l} \pm 2 \mathrm{~S} \text { antandarc } \\
\text { Deviotiations }\end{array}$ & ${ }^{-d} 154 \mathrm{Eu}$ & $\begin{array}{l} \pm 2 \text { Standard } \\
\text { Deviations }\end{array}$ & $155_{E u}$ & $\begin{array}{l} \pm 2 \text { Standard } \\
\text { Deviations }\end{array}$ & $212 \mathrm{pb}$ & $\begin{array}{l} \pm 2 \text { Standard } \\
\text { Deviations }\end{array}$ & ${ }^{214} \mathrm{~Pb}$ & \multicolumn{3}{|l|}{$\begin{array}{l} \pm 2 \text { Standard } \\
\text { Deviations }\end{array}$} \\
\hline L1 & 2.44 & Ø. 25.256 & -0.029 & 0.664 & 0.016 & 0.061 & 0.761 & 0.089 & 0.557 & 0.080 & & \\
\hline L2 & 2.45 & 0.25 .257 & -0.041 & 0.062 & 0.044 & 0.062 & 0.849 & 0.098 & 0.612 & 0.083 & & \\
\hline L3 & 0.958 & 0.10 .108 & -0.051 & 0.067 & 0.050 & 0.055 & 0.574 & 0.073 & 0.521 & 0.058 & & \\
\hline L4 & 2.11 & $0.2^{\prime} c .2^{\prime}<4$ & -0.066 & 0.066 & 0.045 & 0.074 & 0.804 & 0.095 & 0.529 & 0.083 & & \\
\hline L5 & 0.628 & 0.07 .079 & -0.024 & 0.069 & 0.019 & 0.051 & 0.733 & 0.087 & 0.596 & 0.984 & & \\
\hline L6 & 0.491 & 0.06 .065 & 0.082 & 0.066 & 0.625 & 0.075 & 0.768 & 0.092 & 0.490 & 0.080 & & \\
\hline L7 & $\emptyset .576$ & 0.06 .069 & -0.021 & 0.650 & 0.038 & 0.045 & 0.700 & 0.080 & 0.615 & 0.079 & & \\
\hline L8 & 0.772 & 0.09 .095 & -0.035 & 0.088 & -0.095 & 0.067 & 0.859 & 0.105 & 0.743 & 0.101 & & \\
\hline L9 & 0.579 & 0.07 .072 & -0.014 & 0.068 & 0.085 & 0.059 & 0.855 & 0.098 & 0.680 & 0.090 & & \\
\hline
\end{tabular}


IABLE A.5. Concentrations ( $\mathrm{pC} i / \mathrm{g}$ ) of Uranium Isotopes in West Lake Sediments and Salt Deposits

\begin{tabular}{|c|c|c|c|c|c|c|}
\hline Sample Site & $234_{U}$ & $\begin{array}{l} \pm 2 \text { Standard } \\
\text { Deviations }\end{array}$ & $235 U$ & $\begin{array}{l}22 \text { Standard } \\
\text { Deviations }\end{array}$ & $238 U$ & $\begin{array}{l} \pm 2 \text { Standard } \\
\text { Deviations }\end{array}$ \\
\hline L1 & 2.58 & 0.283 & 0.860 & 0.029 & 5.13 & 0.518 \\
\hline L2 & 3.29 & 0.361 & 0.121 & 0.038 & 3.13 & 0.344 \\
\hline L3 & 1.21 & 0.159 & 0.042 & 0.022 & 1.24 & 0.159 \\
\hline L4 & 1.74 & 0.208 & 0.063 & 0.026 & 1.70 & 0.202 \\
\hline L5 & 0.868 & 0.157 & $0.025^{(a)}$ & 0.029 & 0.928 & 0.162 \\
\hline L6 & 0.213 & 0.068 & $0.003^{(a)}$ & 0.015 & 0.201 & 0.066 \\
\hline L7 & 0.853 & 0.123 & 0.034 & 0.019 & 0.921 & 0.127 \\
\hline L8 & 1.30 & 0.177 & 0.047 & 0.025 & 1.21 & 0.167 \\
\hline L9 & 1.82 & 0.208 & 0.069 & 0.025 & 1.94 & 0.218 \\
\hline $\begin{array}{l}\text { Salt } \\
\text { Deposit R-1 }\end{array}$ & 17.4 & 1.70 & 0.568 & 0.092 & 16.4 & 1.60 \\
\hline $\begin{array}{l}\text { Salt } \\
\text { Deposit R-2 }\end{array}$ & 6.61 & 0.722 & 0.247 & 0.064 & 6.23 & 0.683 \\
\hline
\end{tabular}

(a) Results by alpha spectroscopy are less than overall error of \pm 2 standard deviations. 
TABLE A.6. Concentrations ( $\mathrm{pCi} / \mathrm{g}$ by low-energy photon analysis) of Uranium Isotopes in West Lake Basin Soils

\begin{tabular}{|c|c|c|c|c|}
\hline $\begin{array}{l}\text { Sample } \\
\text { Site } \\
\end{array}$ & $235_{U}$ & $\begin{array}{l} \pm 2 \text { Standard } \\
\text { Deviations }\end{array}$ & $238 \mathrm{U}$ & $\begin{array}{l} \pm 2 \text { Standard } \\
\text { Deviations }\end{array}$ \\
\hline Sl & $0.043^{(a)}$ & 0.066 & 0.390 & 0.224 \\
\hline S2 & $0.011^{(a)}$ & 0.091 & 0.787 & 0.268 \\
\hline S3 & 0.061 & 0.061 & 0.566 & 0.210 \\
\hline S4 & 0.122 & 0.057 & 0.702 & 0.212 \\
\hline S5 & 0.075 & 0.060 & 1.91 & 0.350 \\
\hline N1 & 0.130 & 0.064 & 0.926 & 0.200 \\
\hline N2 & $0.036^{(a)}$ & 0.089 & 0.726 & 0.294 \\
\hline N3 & $0.019^{(a)}$ & 0.065 & 0.535 & 0.317 \\
\hline N4 & $5.10^{(a)}$ & 0.067 & 1.12 & 0.244 \\
\hline N5 & 8.20 & 0.062 & 0.628 & 0.185 \\
\hline N6 & 1.49 & 0.089 & 1.79 & 0.358 \\
\hline
\end{tabular}

(a) Results are less than overall error of \pm 2 standard deviations. 
TABLE A.7. Concentrations ( $\mathrm{pCi} / \mathrm{g}-\mathrm{dry}$ ) of Radionuclides in Soils Collected from the North Transect, West Lake Basin

\begin{tabular}{|c|c|c|c|c|c|c|c|c|c|c|c|c|}
\hline $\begin{array}{l}\text { Samp le } \\
\text { Site } \\
\end{array}$ & $4 \theta_{K}$ & $\begin{array}{l} \pm 2 \text { Standard } \\
\text { Deviations }\end{array}$ & ${ }^{60} \mathrm{Co}$ & $\begin{array}{l} \pm 2 \text { Standard } \\
\text { Deviations }\end{array}$ & $9 \theta_{S r}$ & $\begin{array}{l} \pm 2 \text { Standard } \\
\text { Deviations }\end{array}$ & ${ }^{95} \mathrm{zr}^{95} \mathrm{Nb}$ & $\begin{array}{l} \pm 2 \text { Standard } \\
\text { Deviations }\end{array}$ & ${ }^{106_{\mathrm{Ru}}}$ & $\begin{array}{l} \pm 2 \text { Standard } \\
\text { Deviations }\end{array}$ & ${ }^{134} \mathrm{Cs}$ & $\begin{array}{l}\text { 土2 Standaro } \\
\text { Deviations }\end{array}$ \\
\hline $\mathrm{N} 1$ & 16.4 & 1.83 & -8.01 & 0.021 & 0.13 & 9.928 & 0.013 & 0.643 & 0.155 & 0.148 & -0.008 & 0.022 \\
\hline N2 & 16.9 & 1.92 & 0.013 & 0.021 & 0.331 & 0.863 & -0.065 & 0.051 & -0.114 & 0.178 & -0.016 & 0.018 \\
\hline N3 & 16.9 & 1.88 & 0.01 & 0.021 & 0.155 & 0.631 & 0.064 & 0.042 & -6.162 & 0.165 & -6.691 & 0.022 \\
\hline N4 & 18.3 & 2.87 & -0.023 & 0.623 & 9.35 & 9.866 & -0.011 & 0.053 & $-\emptyset .127$ & 0.209 & -0.003 & $\emptyset . \varnothing 19$ \\
\hline N5 & $18 . \varnothing$ & 2.01 & -0.01 & 0.021 & 0.326 & 6866 & -0.018 & 0.044 & 0.002 & 0.143 & -0.049 & $\emptyset . \varnothing 19$ \\
\hline N6 & 16.9 & 1.85 & 0.008 & 0.015 & 0.141 & 0029 & -0.026 & 0.036 & 0.069 & 0.123 & -0.012 & 0.013 \\
\hline $\begin{array}{l}\text { Sample } \\
\text { Site } \\
\end{array}$ & ${ }^{137}$ Cs & $\begin{array}{l} \pm 2 \text { Standard } \\
\text { Deviations }\end{array}$ & ${ }^{154} \mathrm{Eu}$ & $\begin{array}{l} \pm 2 \text { Standard } \\
\text { Deviations }\end{array}$ & ${ }^{155_{\mathrm{Eu}}}$ & $\begin{array}{l} \pm Z \text { St mndlard } \\
\text { Devia ions }\end{array}$ & $\underline{212} \mathrm{~Pb}$ & $\begin{array}{l} \pm 2 \text { Standard } \\
\text { Deviations }\end{array}$ & ${ }^{214} \mathrm{~Pb}$ & $\begin{array}{l} \pm 2 \text { Standard } \\
\text { Deviations }\end{array}$ & & \\
\hline N1 & 0.928 & 0.106 & -0.075 & 0.664 & 0.11 & 9065 & 0.658 & 0.079 & 0.62 & 0.985 & & \\
\hline N2 & 1.66 & 0.122 & 0.052 & 0.074 & 0.065 & 0.077 & 0.765 & 0.087 & 0.526 & 0.081 & & \\
\hline N3 & 1.1 & 0.123 & -0.051 & 0.665 & $-\emptyset .049$ & 0.066 & 0.791 & 0.084 & 0.605 & 0.683 & & \\
\hline N4 & 1.34 & 0.152 & 0.02 & 0.071 & 0.12 & 0.68 .8 & 0.696 & 0.088 & 0.513 & 0.685 & & \\
\hline N5 & 0.94 & 0.107 & 0.031 & 0.064 & 0.004 & $0.05: 9$ & 0.713 & 0.084 & 0.528 & 0.078 & & \\
\hline N6 & 57.4 & 0.069 & -0.064 & 0.05 & 0.063 & 064.4 & 0.664 & 0.076 & 0.584 & 0.076 & & \\
\hline
\end{tabular}


TABLE A.8. Concentrations ( $p C i / g-d r y$ ) of Radionuclides in Soils Collected from the South Transect, West Lake Basin

\begin{tabular}{|c|c|c|c|c|c|c|c|c|c|c|c|c|}
\hline $\begin{array}{l}\text { Samp le } \\
\text { Site } \\
\end{array}$ & ${ }^{4 g_{K}}$ & $\begin{array}{l} \pm 2 \text { Standard } \\
\text { Deviations }\end{array}$ & ${ }^{60} \mathrm{Co}$ & $\begin{array}{l} \pm 2 \text { Standard } \\
\text { Deviations }\end{array}$ & ${ }^{90} \mathrm{Sr}$ & $\begin{array}{l} \pm 2 \text { Standard } \\
\text { Deviations }\end{array}$ & ${ }^{95} \mathrm{Zr}^{95} \mathrm{Nb}$ & $\begin{array}{l} \pm 2 \text { Standard } \\
\text { Deviations }\end{array}$ & $\frac{106}{\mathrm{Ru}}$ & $\begin{array}{l} \pm 2 \text { Standard } \\
\text { Deviations }\end{array}$ & ${ }^{134} \mathrm{Cs}$ & $\begin{array}{l} \pm 2 \text { Standard } \\
\text { Deviations }\end{array}$ \\
\hline S1 & 16.5 & 1.84 & -0.016 & 0.017 & 0.109 & 0.024 & -0.034 & 0.033 & 0.058 & 0.117 & 0.005 & 0.013 \\
\hline S2 & 16.6 & 1.84 & 0.011 & 0.017 & 0.36 & 0.07 & -0.018 & 0.042 & 0.061 & 0.135 & -0.054 & 0.020 \\
\hline S3 & 16.9 & 1.86 & -0.032 & 0.014 & 0.173 & 0.036 & -0.041 & 0.036 & 0.057 & 0.123 & -0.007 & 0.013 \\
\hline S4 & 16.3 & 1.91 & 0.023 & 0.023 & 0.136 & 0.029 & -0.042 & 0.05 & 0.092 & 0.171 & -0.006 & 0.023 \\
\hline S5 & 14.1 & 1.56 & -0.018 & 0.016 & 0.671 & 0.13 & -0.017 & 0.034 & 0.023 & 0.123 & 0.044 & 0.016 \\
\hline $\begin{array}{l}\text { Sample } \\
\text { Site }\end{array}$ & ${ }^{137} \mathrm{Cs}$ & $\begin{array}{l} \pm 2 \text { Standard } \\
\text { Deviations }\end{array}$ & ${ }^{154} \mathrm{Eu}$ & $\begin{array}{l} \pm 2 \text { Standard } \\
\text { Deviations }\end{array}$ & ${ }^{155_{\mathrm{Eu}}}$ & $\begin{array}{l} \pm 2 \text { Standard } \\
\text { Deviations }\end{array}$ & ${ }^{212} \mathrm{~Pb}$ & $\begin{array}{l} \pm 2 \text { Standard } \\
\text { Deviations }\end{array}$ & ${ }^{214} \mathrm{~Pb}$ & 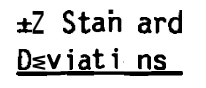 & & \\
\hline S1 & 1.17 & 0.129 & 0.066 & 0.058 & 0.007 & 0.056 & 0.712 & 0.083 & $\emptyset .569$ & 0.679 & & \\
\hline S2 & 1.25 & 0.137 & 0.1 & 0.054 & 0.039 & 0.053 & 0.707 & 0.082 & 0.556 & 0.076 & & \\
\hline S3 & 0.502 & 0.623 & -0.041 & 0.054 & 0.033 & 0.045 & 0.603 & 0.073 & 0.514 & 0.073 & & \\
\hline S4 & 0.229 & 0.426 & -0.003 & 0.08 & -0.019 & 0.064 & 0.692 & 0.086 & 0.684 & 0.097 & & \\
\hline S5 & 1.52 & 0.16 & -0.028 & 0.052 & 0.075 & 0.05 & 0.818 & 0.091 & $\emptyset .588$ & 0.076 & & \\
\hline
\end{tabular}


TABLE A.9. Concentrations $(\mathrm{pCi} / \mathrm{g})$ of Radionucl ides in Vegetation Collected from the North Transect, West Lake Basin

\begin{tabular}{|c|c|c|c|c|c|c|c|c|c|c|c|c|}
\hline $\begin{array}{c}\text { Sample } \\
\text { Site }\end{array}$ & $77_{\mathrm{Be}}$ & $\begin{array}{l}\text { 土2 Standard } \\
\text { Deviations }\end{array}$ & $4 \theta_{K}$ & $\begin{array}{l}\text { 土2 Standard } \\
\text { Deviations }\end{array}$ & ${ }^{60} \mathrm{Co}$ & $\begin{array}{l}\text { 士2 Standard } \\
\text { Deviations }\end{array}$ & ${ }^{90} \mathrm{Sr}$ & $\begin{array}{l}\text { 土2 Standard } \\
\text { Deviations }\end{array}$ & ${ }^{95} \mathrm{Zr}^{95} \mathrm{Nb}$ & $\begin{array}{l} \pm 2 \text { Standard } \\
\text { Deviations }\end{array}$ & $185_{2.1}$ & $\begin{array}{l} \pm 2 \text { Standard } \\
\text { Deviations }\end{array}$ \\
\hline N1 & 5.06 & 1.2 & 11 & 2.5 & 7.930 & 0.104 & 0.419 & 0.085 & -0.051 & 0.243 & -0.674 & 0.836 \\
\hline N2 & 3.04 & 0.739 & 6.18 & 1.37 & -0.032 & 0.048 & 0.173 & 0.035 & -0.006 & 0.107 & 0.178 & 0.391 \\
\hline N3 & 2.98 & 0.716 & 7.11 & 1.68 & -0.019 & 0.051 & 0.018 & 0.008 & 0.011 & 0.12 & -0.16 & 0.415 \\
\hline N4 & 1.63 & 0.543 & 12.8 & 1.92 & -0.029 & 0.045 & 0.024 & 0.01 & -0.031 & 0.115 & -0.393 & 0.341 \\
\hline N5 & 2.77 & 0.714 & 10.2 & 1.97 & 0.027 & 0.061 & 0.051 & 0.014 & 0.059 & 0.144 & 0.464 & 0.397 \\
\hline N6 & 4.04 & 0.871 & 6.34 & 1.21 & 0.931 & 9.947 & 9.028 & 0.009 & -0.02 & 0.116 & 0.426 & 0.426 \\
\hline $\begin{array}{l}\text { Sample } \\
\text { Site }\end{array}$ & ${ }^{134} \mathrm{Cs}$ & $\begin{array}{l} \pm 2 \text { Standard } \\
\text { Deviations }\end{array}$ & 137 Cs_ & $\begin{array}{l} \pm 2 \text { Standard } \\
\text { Deviations }\end{array}$ & ${ }^{154} \mathrm{Eu}_{-}$ & $\begin{array}{l} \pm 2 \text { Standard } \\
\text { Deviations }\end{array}$ & $.155_{\mathrm{Eu}}$ & $\begin{array}{l}\text { 土2 Standard } \\
\text { Deviations }\end{array}$ & ${ }^{212} \mathrm{~Pb}_{-}$ & $\begin{array}{l}\text { 土2 Standard } \\
\text { Deviations }\end{array}$ & ${ }^{214} \mathrm{~Pb}$ & $\begin{array}{l} \pm 2 \text { Standard } \\
\text { Deviations }\end{array}$ \\
\hline N1 & -0.1 & 0.694 & 0.062 & 0.097 & -0.135 & 0.266 & -0.015 & 0.2 & 0.174 & 0.164 & NR & --- \\
\hline N2 & -0.012 & 0.042 & 0.056 & 0.042 & -0.058 & 0.127 & -0.01 & 0.107 & 0.113 & 0.685 & NR & --- \\
\hline N3 & -0.029 & 0.048 & 0.031 & 0.046 & 0.086 & อ. 142 & 0.03 & e. 113 & 0.004 & 0.089 & NR & --- \\
\hline N4 & -0.008 & 0.044 & -0.039 & 0.045 & 0.063 & 0.137 & 0.095 & 0.111 & 0.038 & 0.682 & NR & -- \\
\hline N5 & 9.059 & 0.952 & 0.135 & 0.058 & -0.191 & 0.192 & 0.022 & 0.146 & 0.221 & 0.694 & NR & --- \\
\hline N6 & -0.008 & 0.047 & 0.046 & 0.049 & -0.07 & 0.153 & 0.024 & 0.111 & 0.001 & 0.074 & 8.102 & 0.096 \\
\hline
\end{tabular}

$\mathbf{R}=\mathbf{N o t}$ reported. 

TABLE A.10. Concentrations ( $\mathrm{pCi} / \mathrm{g}$ ) of Radionuclides in Vegetation Collected from the South
Transect, West Lake Basin

\begin{tabular}{|c|c|c|c|c|c|c|c|c|c|c|c|c|}
\hline $\begin{array}{l}\text { Samp le } \\
\text { Site- }\end{array}$ & ${ }^{7} \mathrm{Be}-$ & $\begin{array}{l} \pm 2 \text { Standard } \\
\text { Deviations }\end{array}$ & ${ }^{4 \sigma_{K}}$ & $\begin{array}{l}22 \text { Standard } \\
\text { Deviations }\end{array}$ & ${ }^{60} \mathrm{Co}$ & $\begin{array}{l} \pm 2 \text { Standard } \\
\text { Deviations }\end{array}$ & ${ }^{98} \mathrm{Sr}$ & $\begin{array}{l} \pm 2 \text { Standard } \\
\text { Deviations }\end{array}$ & ${ }^{95} \mathrm{Zr}^{95} \mathrm{Nb}$ & $\begin{array}{l}\text { t2 Standard } \\
\text { Deviations }\end{array}$ & ${ }^{106} \mathrm{Ru}$ & $\begin{array}{l} \pm 2 \text { Standard } \\
\text { Deviations }\end{array}$ \\
\hline S1 & 4.02 & 0.897 & 8.34 & 1.51 & -0.021 & 0.058 & 0.079 & 0.02 & -0.173 & 0.125 & 0.099 & 0.446 \\
\hline S2 & 4.95 & 0.969 & 6.67 & 1.43 & 0.045 & 0.053 & 0.245 & 0.051 & 0.125 & 0.132 & -0.192 & 0.454 \\
\hline S3 & 5.86 & 1.12 & 6.58 & 1.68 & 0.092 & 0.659 & 0. 061 & 0.018 & -0.102 & 0.158 & 6.194 & 0.544 \\
\hline S4 & 4.95 & 0.98 & 3.75 & 1.42 & 0.01 & 0.053 & 0.503 & 0.1 & 0.023 & 0.127 & -0.363 & 0.457 \\
\hline S5 & 0.635 & 1.3 & 6.16 & 3.32 & -0.014 & 0.124 & 0.119 & 0.035 & 0.144 & 0.281 & 0.726 & 1.16 \\
\hline $\begin{array}{l}\text { Sample } \\
\text { Site } \\
\end{array}$ & ${ }^{134} \mathrm{Cs}$ & $\begin{array}{l} \pm 2 \text { Standard } \\
\text { Deviations }\end{array}$ & ${ }^{137} \mathrm{Cs}$ & $\begin{array}{l} \pm 2 \text { Standard } \\
\text { Deviations }\end{array}$ & ${ }^{154} \mathrm{Eu}$ & $\begin{array}{l} \pm 2 \text { Standard } \\
\text { Deviations }\end{array}$ & ${ }^{155_{\mathrm{EU}}}$ & $\begin{array}{l} \pm 2 \text { Standard } \\
\text { Deviations }\end{array}$ & ${ }^{212} \mathrm{~Pb}$ & $\begin{array}{l}22 \text { Standard } \\
\text { Deviations }\end{array}$ & & \\
\hline S1 & -0.035 & 0.05 & 0.05 & 0.053 & -0.096 & 0.152 & 0.08 & 0.143 & 0.135 & 0.101 & & \\
\hline S2 & -0.002 & 0.05 & 0.096 & 0.061 & -0.09 & 0.163 & -0.007 & 0.163 & 0.697 & 0.11 & & \\
\hline S3 & 0.049 & 0.063 & 0.267 & 0.081 & -0.156 & 0.186 & -0.074 & 0.147 & 0.133 & 0.11 & & \\
\hline S4 & -0.041 & 0.056 & 0.058 & 0.052 & -0.022 & 0.156 & 0.029 & 0.141 & 0.495 & 0.129 & & \\
\hline S5 & -0.157 & 0.129 & 0.212 & 0.156 & 0.218 & 0.349 & 0.087 & 6. 368 & 0.353 & 6. 194 & & \\
\hline
\end{tabular}


TABLE A.Il. Concentrations $(\mathrm{pC} / \mathrm{g}$ ) of Uranium Isotopes in West Lake Basin Vegetation

\begin{tabular}{|c|c|c|c|c|c|c|}
\hline $\begin{array}{l}\text { Sample } \\
\text { Site }\end{array}$ & $234 U$ & $\begin{array}{l}22 \text { Standard } \\
\text { Deviations }\end{array}$ & ${ }^{235} \mathrm{U}$ & $\begin{array}{l} \pm 2 \text { Standard } \\
\text { Deviations } \\
\end{array}$ & ${ }^{238} \mathrm{U}_{\mathrm{Z}}$ & $\begin{array}{l}\text { 22 Standard } \\
\text { Deviations }\end{array}$ \\
\hline S1 & 0.016 & 0.005 & $0.001^{(a)}$ & 0.001 & 0.015 & 0.004 \\
\hline S2 & 0.043 & 0.007 & 0.001 & 0.001 & 0.044 & 0.008 \\
\hline S3 & 0.076 & 0.011 & 0.002 & 0.001 & 0.06 & 0.010 \\
\hline 54 & 0.076 & 0.012 & $0.001^{(a)}$ & 0.002 & 0.073 & 0.011 \\
\hline S5 & 0.554 & 0.077 & 0.017 & 0.007 & 0.505 & 0.071 \\
\hline $\mathrm{N} 1$ & 0.043 & 0.009 & $0.002^{(a)}$ & 0.002 & 0.036 & 0.008 \\
\hline N2 & 0.038 & 0.008 & $0.001^{(a)}$ & 0.001 & 0.029 & 0.007 \\
\hline N3 & 0.021 & 0.005 & $0.0003^{(a)}$ & 0.001 & 0.019 & 0.005 \\
\hline N4 & 0.039 & 0.008 & $-0.0003^{(a)}$ & 0.001 & 0.037 & 0.008 \\
\hline N5 & 1.19 & 0.124 & 0.040 & 0.008 & 1.14 & 0.119 \\
\hline N6 & 1.79 & 0.176 & 0.068 & 0.011 & 1.68 & 0.166 \\
\hline
\end{tabular}

(a) Results are less than overall error of 22 standard deviations. 
TABLE A.12. Concentrations ( $\mathrm{pC} \mathrm{i} / \mathrm{g}$ ) of Selected Radionuclides in Coot Eggshells Collected from West Lake (WL) and Morgan Lake (ML)

\begin{tabular}{|c|c|c|c|c|c|c|c|c|}
\hline $\begin{array}{l}\text { Sample } \\
\text { Number }\end{array}$ & $40_{K}$ & $\begin{array}{l}\text { 土2 Standard } \\
\text { Deviations }\end{array}$ & ${ }^{60} \mathrm{Co}$ & $\begin{array}{l} \pm 2 \text { Standard } \\
\text { Deviations }\end{array}$ & ${ }^{65} \mathrm{Zn}$ & $\begin{array}{l} \pm 2 \text { Standard } \\
\text { Deviations }\end{array}$ & ${ }^{9 \theta_{S r}}$ & $\begin{array}{l} \pm 2 \text { Standard } \\
\text { Deviations }\end{array}$ \\
\hline WL No. 1 & 2.04 & 2.37 & -0.028 & 0.137 & 0.087 & 0.519 & 4.66 & 1.05 \\
\hline WL No. 2 & 8.73 & 3.48 & -0.075 & 0.303 & -0.628 & 0.889 & 5.59 & 1.02 \\
\hline $\mathbf{M}$ No. 3 & 7.11 & 6.31 & -0.244 & 0.285 & -0.606 & 1.15 & 0.1 & 0.034 \\
\hline M No. 4 & 18.3 & 3.69 & 0.066 & 0.163 & -0.575 & 0.707 & 0.064 & 0.038 \\
\hline $\begin{array}{l}\text { Sample } \\
\text { Number }\end{array}$ & ${ }^{137} \mathrm{Cs}$ & $\begin{array}{l} \pm 2 \text { Standard } \\
\text { Deviations }\end{array}$ & $\stackrel{234}{U}$ & $\begin{array}{l} \pm 2 \text { Standard } \\
\text { Deviations }\end{array}$ & ${ }^{235_{U}}$ & $\begin{array}{l} \pm 2 \text { Standard } \\
\text { Deviations }\end{array}$ & ${ }^{238} \mathrm{U}$ & $\begin{array}{l} \pm 2 \text { Standard } \\
\text { Deviations }\end{array}$ \\
\hline WL No. 1 & -0.005 & 0.118 & 0.004 & 0.003 & 0.000 & 0.001 & 0.003 & 0.002 \\
\hline W No. 2 & -0.025 & 0.223 & 0.013 & 0.004 & 0.001 & 0.001 & 0.008 & 0.003 \\
\hline $\mathbf{M}$ No. 3 & -0.062 & 0.269 & 0.001 & 0.001 & 0.0002 & 0.001 & 0.002 & 0.001 \\
\hline ML No. 4 & -0.046 & 0.132 & 0.005 & 0.035 & 0.004 & 0.003 & 0.004 & 0.003 \\
\hline
\end{tabular}


TABLE A. 13. Minimum Detectable Conçentrations for Radionucl ides in Environmental Samples (a)

\begin{tabular}{|c|c|c|c|c|}
\hline Radionucl ide & $\begin{array}{c}\text { Water } \\
(\mathrm{pCi} / \mathrm{L})\end{array}$ & $\begin{array}{l}\text { Sediment } \\
(\mathrm{pCi} / \mathrm{q})\end{array}$ & $\begin{array}{c}\text { Soi } 1 \\
(p C i / q)\end{array}$ & $\begin{array}{l}\text { Vegetation } \\
(\mathrm{pC} i / q)\end{array}$ \\
\hline $3_{H}$ & 300 & NA & NA & NA \\
\hline${ }^{7} \mathrm{Be}$ & NA & NA & NA & 0.23 \\
\hline $40_{K}$ & 140 & 0.35 & 0.35 & 0.53 \\
\hline${ }^{60} \mathrm{Co}$ & 9 & 0.02 & 0.02 & 0.03 \\
\hline${ }^{65} \mathrm{Zn}$ & 17 & 0.04 & 0.04 & NA \\
\hline${ }^{90} \mathrm{Sr}$ & 0.6 & 0.005 & 0.005 & 0.005 \\
\hline${ }^{95} \mathrm{Zr}^{95} \mathrm{Nb}$ & 14 & 0.03 & 0.03 & 0.05 \\
\hline${ }^{99} \mathrm{Tc}$ & 15.0 & $N A$ & NA & NA \\
\hline${ }^{106} \mathrm{Ru}$ & 69 & 0.017 & 0.017 & 0.26 \\
\hline & NA & 0.02 & 0.02 & 0.03 \\
\hline${ }^{137} \mathrm{Cs}$ & 8 & 0.02 . & 0.02 & 0.03 \\
\hline & 22 & 0.05 & 0.05 & 0.08 \\
\hline${ }^{155} \mathrm{Eu}$ & 19 & 0.05 & 0.05 & 0.07 \\
\hline${ }^{212} \mathrm{~Pb}(\mathrm{~b})$ & NA & 0.02 & 0.02 & 0.03 \\
\hline${ }^{214} \mathrm{~Pb}(\mathrm{~b})$ & NA & 0.02 & 0.02 & 0.03 \\
\hline${ }^{234} U$ & 0.6 & NA & NA & 0.1 \\
\hline $235 \mathrm{U}$ & 0.6 & $1.0^{(c)}$ & $1.0^{(c)}$ & 0.1 \\
\hline${ }^{238} U$ & 0.6 & $1.0^{(c)}$ & $1.0^{(c)}$ & 0.1 \\
\hline
\end{tabular}

(a) Analytical detection concentrations taken from contract specifications and Jaquish and Bryce (1990).

(b) Based on reported ${ }^{13} \mathrm{Cs}$ detection 1 imit in Jaquish and Bryce (1990).

(c) Soil and sediment analyzed by low-energy photon detection (LEPD) system.

$\mathrm{NA}=$ Not analyzed . 


\section{APPENDIX B}

ORGANIC CONTAMINANTS IN WEST LAKE WATER 


\section{APPENDIX B}

\section{ORGANIC CONTAMINANTS IN WEST LAKE WATIR}

This appendix contains data from analytical reports provided by United States Testing Company, Inc. on surface-water samples collected from West Lake in August 1989. The organic constituents summarized in this appendix include volatile and semivolatile organic compounds, nonvolatile organic compounds, herbicides, pesticides, polychlorinated biphenyls, and thiourea compounds.

B.1 
TABLE B.1. Volatile and Semivolatile Organic Compounds Analyzed in West Lake Water

\begin{tabular}{|c|c|c|c|}
\hline Compound & $\begin{array}{l}\text { Water } \\
(\mathrm{mg} / \mathrm{L})(\mathrm{a})\end{array}$ & Compound & $\begin{array}{r}\text { Water } \\
\left(\mathrm{mq} \mathbf{\prime}^{\prime} \mathrm{L}\right)\end{array}$ \\
\hline Carbon tetrachloride & $<5$ & 1,2-Dichlorobenzene & $<12$ \\
\hline Benzene & $<5$ & 1,3-Dich1orobenzene & $<12$ \\
\hline Methyl ethyl ketone & $<10$ & Hexachl orobenzene & $<12$ \\
\hline Toluene & $<5$ & Pentachlorobenzene & $<12$ \\
\hline $1,1,1$-Trichloroethane & $<5$ & Pentachlorophenol & $t 60$ \\
\hline 1,1,2-Trichloroethane & $<5$ & $1,2,4,5$-Tetrachlorobenzene & $<12$ \\
\hline Trichloroethylene & $<5$ & 1,2,4-Trichlorobenzene & $<12$ \\
\hline Tetrachloroethylene & $<5$ & Hexachlorophene & 26 \\
\hline Xylene $(0, p)$ & $<5$ & Naphtha1ene & $<12$ \\
\hline Chloroform & $<5$ & 1,2,3-Trichlorobenzene & $<12$ \\
\hline 1,1-Dichloroethane & $<5$ & Phenol & $<12$ \\
\hline 1,2-Dichloroethane & $<5$ & 1,3,5-Trichlorobenzene & $<12$ \\
\hline Trans-1,2-Dichloroethylene & $<5$ & $1,2,3,4$-Tetrachlorobenzene & $<12$ \\
\hline Methylene chloride & $<5$ & $1,2,3,5$-Tetrachlorobenzene & $<12$ \\
\hline Vinyl chloride & $<10$ & Kerosene & $<12$ \\
\hline Xylene (M) & $<5$ & Strychnine & $<12$ \\
\hline Methyl isobutyl ketone & $<10$ & Maleic hydrazide & $<12$ \\
\hline Acetone & $<10$ & Nicotinic acid & $<12$ \\
\hline Tetrahydrofuran & $<10$ & Tributylphosphate & $<12$ \\
\hline 1-4-Dich1orobenzene & $<5$ & Chlorobenzene & $<12$ \\
\hline Cresol & $<12$ & & \\
\hline
\end{tabular}

(a) The less than $(<)$ sign indicates the reported detection limit 
TABLE B.2. Nonvolatile Organic Compounds Analyzed in West Lake Water

\begin{tabular}{lc}
\multicolumn{1}{c}{ Compound } & $\begin{array}{c}\text { Water } \\
(\mathrm{mg} / \mathrm{L})\end{array}$ \\
\hline Paraldehyde & $<10$ \\
Acryl amide & $<10$ \\
Allyl alcohol & $<10$ \\
3-Chloropropioni trile & $<10$ \\
Ethyl carbamate & $<10$ \\
Ethyl cyanide & $<10$ \\
Isobutyl alcohol & $<10$ \\
n-Propyl amine & $<10$ \\
2-Propyn-1-0I & $<10$ \\
1-Butanol & $<10$ \\
Ethanol & $<10$ \\
Monobutyl phosphate & $<10$ \\
Di butyl phosphate & $<10$ \\
Ethylene glycol & $<10$ \\
1-Propanol & $<10$ \\
3-Butyn-1-0l & $<10$ \\
&
\end{tabular}


TABLE B.3. Herbicides and Pesticides in West Lake Water

\begin{tabular}{|c|c|c|c|}
\hline Compound & $\begin{array}{l}\text { Water } \\
(\mathrm{mg} / \mathrm{L})(\mathrm{a})\end{array}$ & Compound & $\begin{array}{l}\text { Water } \\
(\mathrm{mg} / \mathrm{L})\end{array}$ \\
\hline $2,4-D$ & $<2.0$ & Kepone & $<1.0$ \\
\hline 2,4,5-TP (Silvex) & $<2.0$ & Dieldrin & $<0.1$ \\
\hline $2,4,5-T$ & $<2.0$ & Aldrin & $<0.1$ \\
\hline Endrin & $<0.1$ & Chlordane & $<1.0$ \\
\hline Methoxychlor & $<3.0$ & Endosulfan I & $<0.1$ \\
\hline Toxaphene & $<1.0$ & Endosulfan II & $<0.1$ \\
\hline Alpha BHC' & $<0.1$ & Endo. Sulfate & $<0.5$ \\
\hline Beta $\mathrm{BHC}$ & $<0.1$ & Chlorobenzi 1ate & $<300$ \\
\hline Gamma BHC & $<0.1$ & Tetraethyl pyrophosphate & $<2.0$ \\
\hline Delta BHC & $<0.1$ & Carbophenothion & $<2.0$ \\
\hline $4,4^{\prime}-\mathrm{DDD}$ & $<0.1$ & Disulfoton & $<2.0$ \\
\hline $4,4^{\prime}-D D E$ & $<0.1$ & Dimethoate & $<2.0$ \\
\hline $4,4^{\prime}$-DDT & $<0.1$ & Methyl parathion & $<2.0$ \\
\hline Heptachlor & $<0.1$ & Parathion & $<2.0$ \\
\hline Heptepoxide & $<0.1$ & Phorate & $<2.0$ \\
\hline
\end{tabular}

(a) The less than $(<)$ sign indicates the reported detection limit.

TABLE B.4. Polychlorinated Biphenyl (PCB) Congeners Analyzed in West Lake Water

\begin{tabular}{l} 
Compounds \\
\hline Arochlor-1016 \\
Arochlor-1221 \\
Arochlor -1232 \\
Arochlor 1242 \\
Arochlor-1248 \\
Arochlor-1254 \\
Arochlor- 1260
\end{tabular}

$\begin{gathered}\text { Water } \\ (\mathrm{mg} / \mathrm{L})\end{gathered}$
$<1$
$<1$
$<1$
$<1$
$<1$
$<1$
$<1$
$<1$

(a) The less than $(<)$ sign indicates the reported detection limit. 
TABLE B.5. Enhanced Thiourea Compounds in West Lake Water

\begin{tabular}{lc}
\multicolumn{1}{c}{ Compound } & $\begin{array}{c}\text { Water } \\
(\mathrm{mg} / \mathrm{L})\end{array}$ \\
\hline Thiourea
\end{tabular}

(a) The less than $(<)$ sign indicates the reported detection limit. 
APPENDIX C

HISTORICAL LEVELS OF CONTAMINANTS IN WEST LAKE AND GROUND WATER 


\section{APPENDIX C}

\section{HISTORICAL LEVELS OF CONTAMINANTS IN WEST LAKE AND GROUND WATIR}

This appendix contains a series of figures generated from the Hanford Ground Water Data Base (HGWDB). These figures show trends in the historical concentrations of contaminants in the ground-water samples collected from wells located in the vicinity of West Lake. 

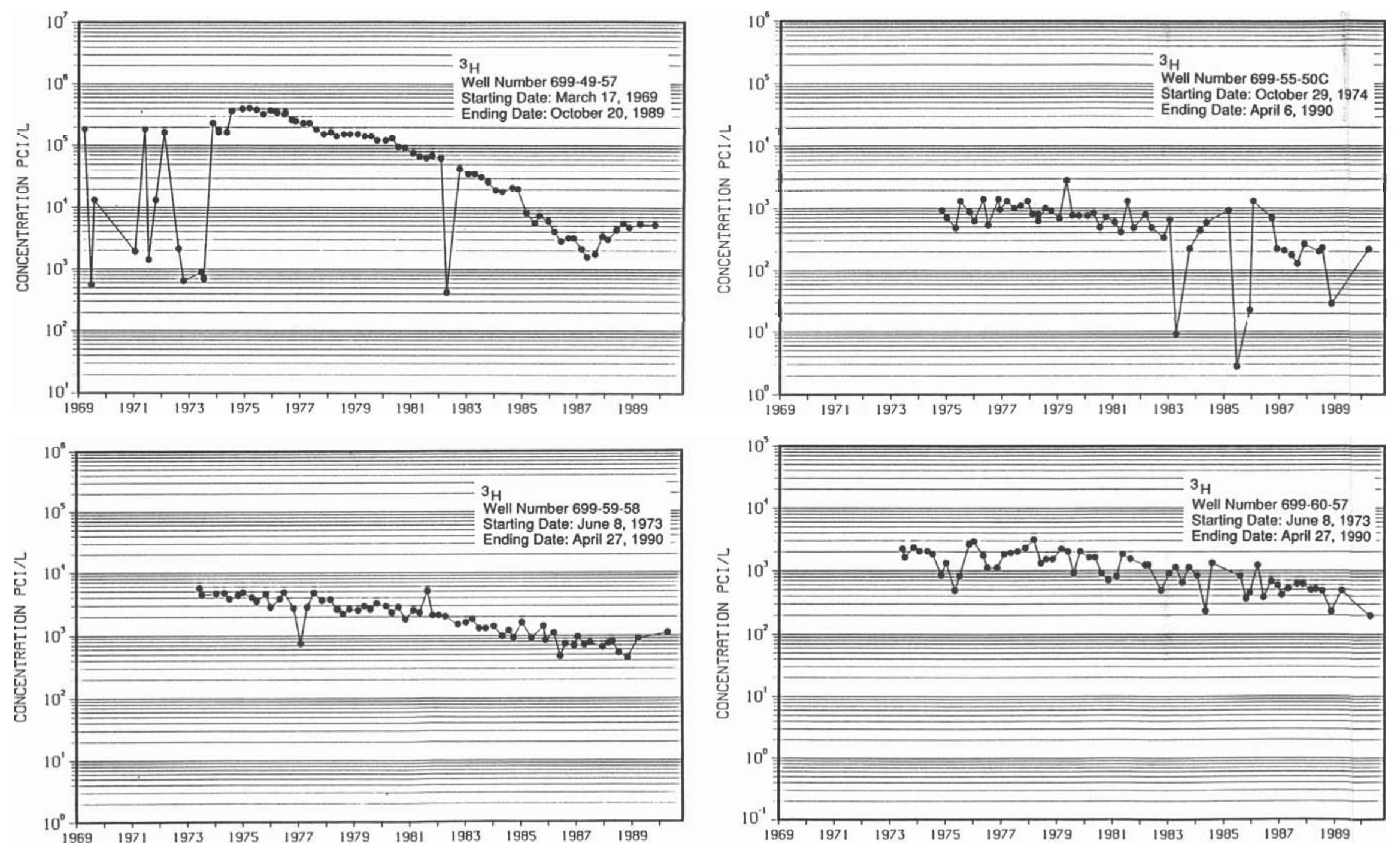

FIGURE C.1. Historical Levels of ${ }^{3} \mathrm{H}$ on the Hanford Site in Selected Wells 

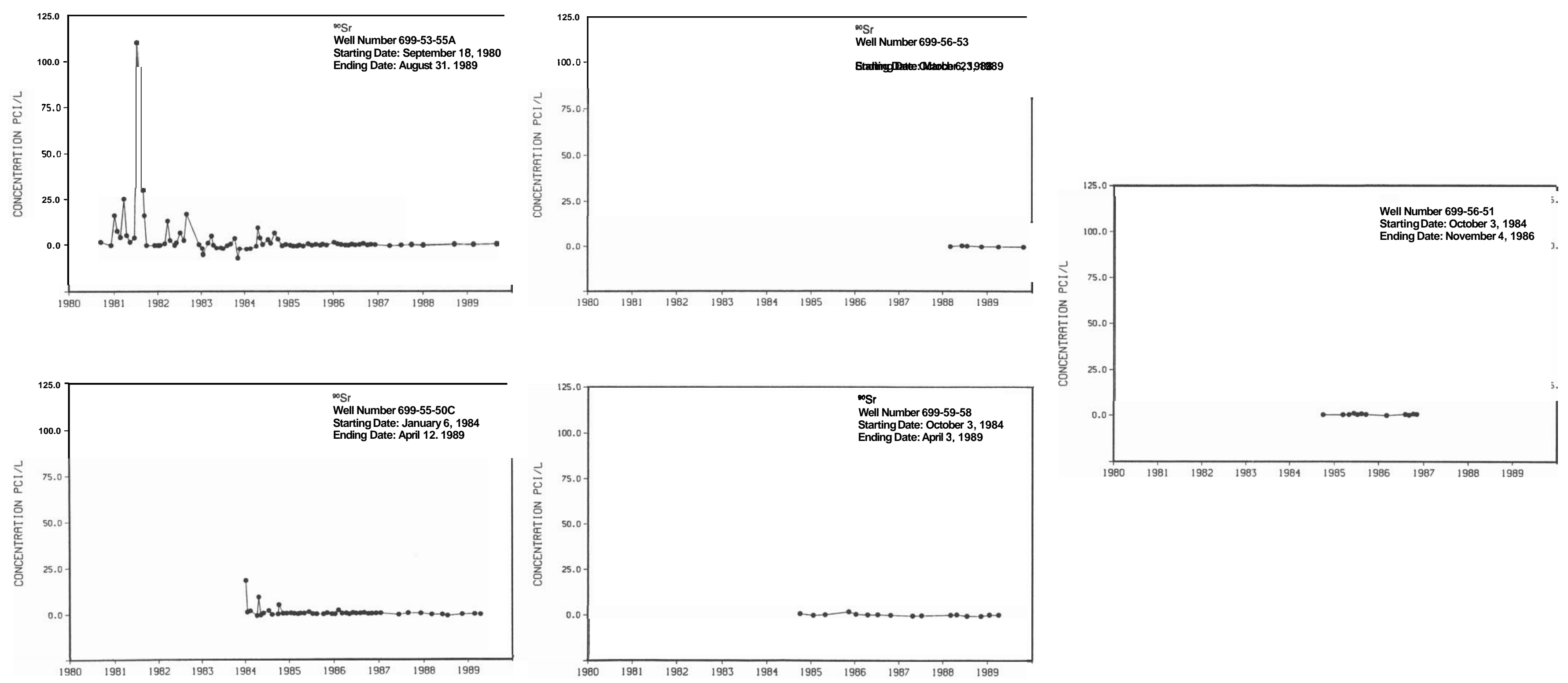

FIGURE C.2. Historical Levels of ${ }^{90} \mathrm{Sr}$ on the Hanford Site in Selected Wells 

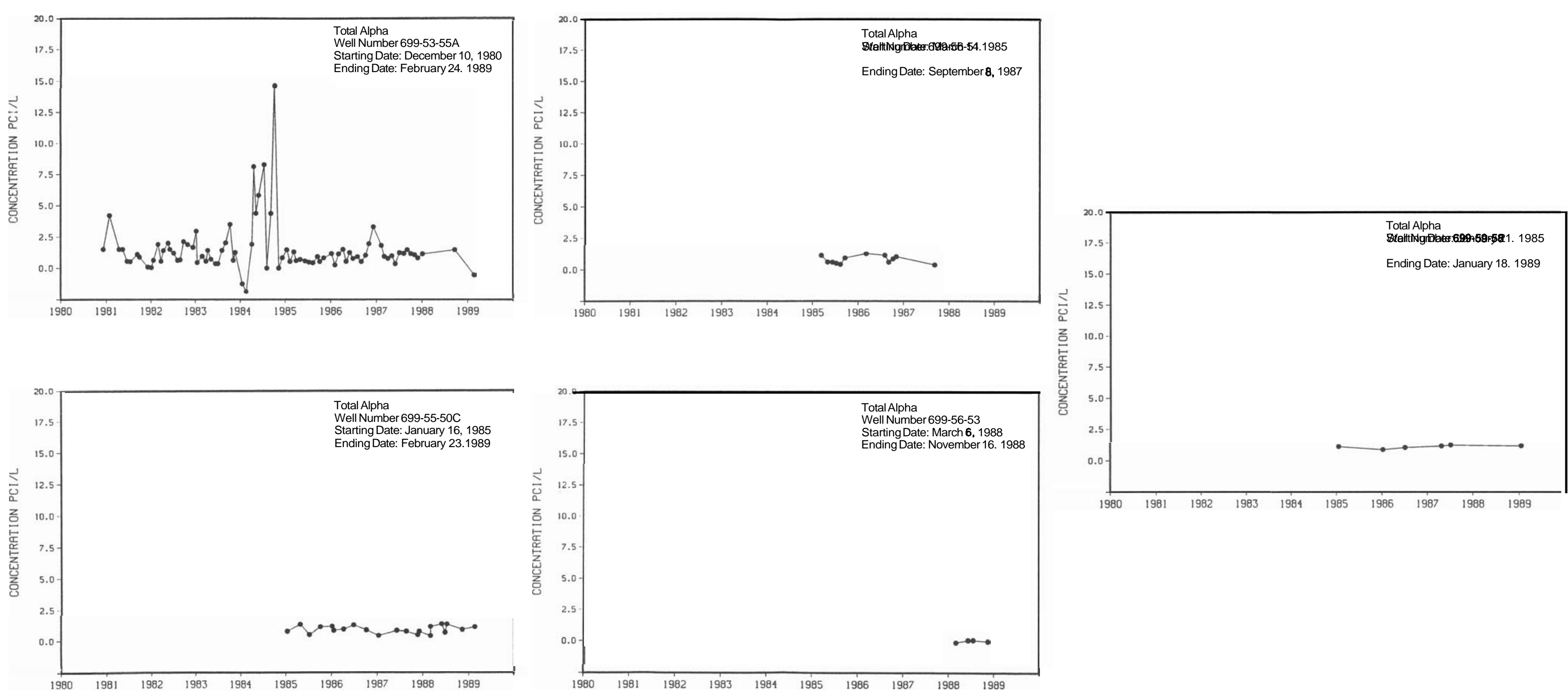

FIGURE C.3. Historical Levels of Total Alpha on the Hanford Site in Selected Wells 

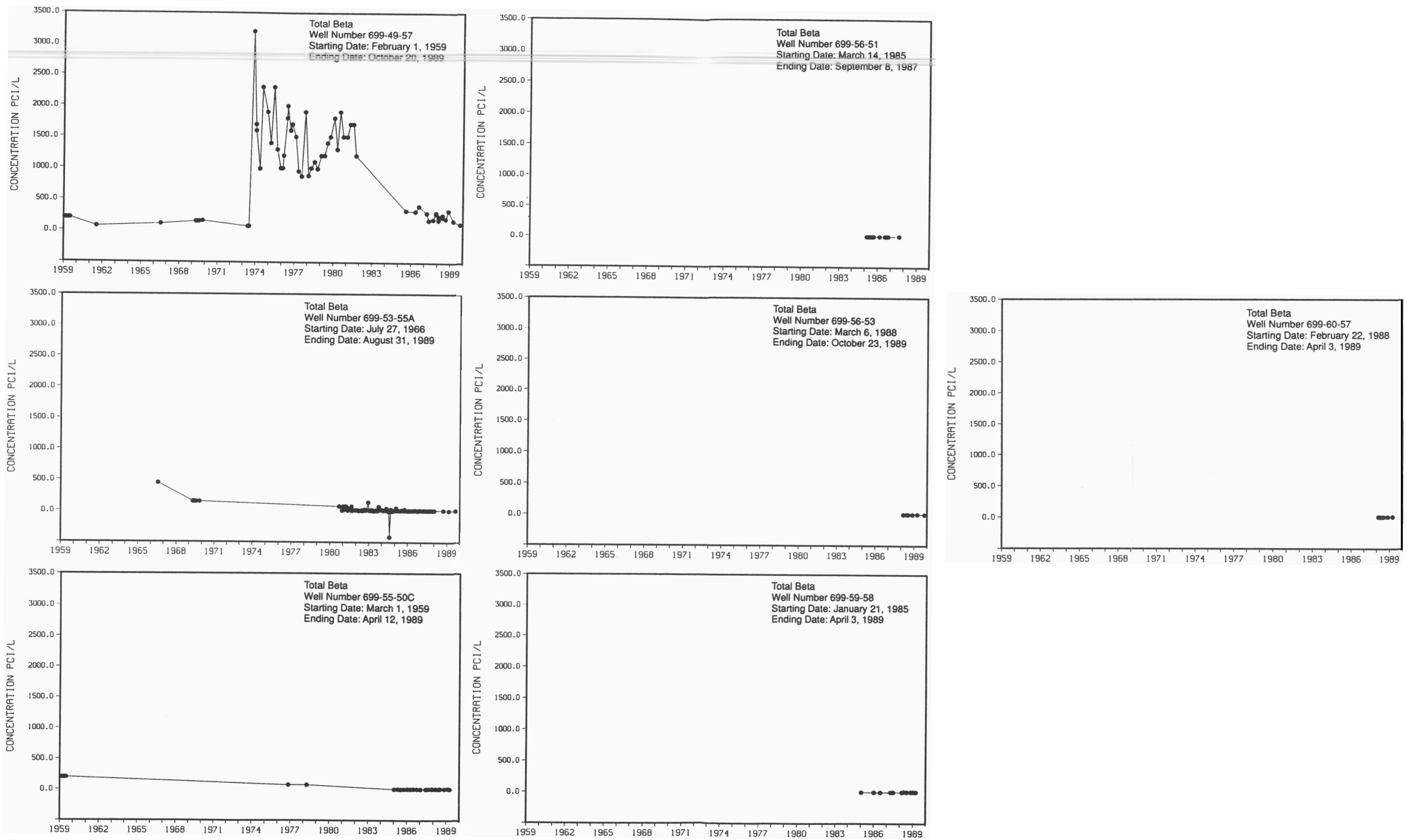

FIGURE C.4 Historical Levels of Total Beta on the Hanford Site in Selected Wells 


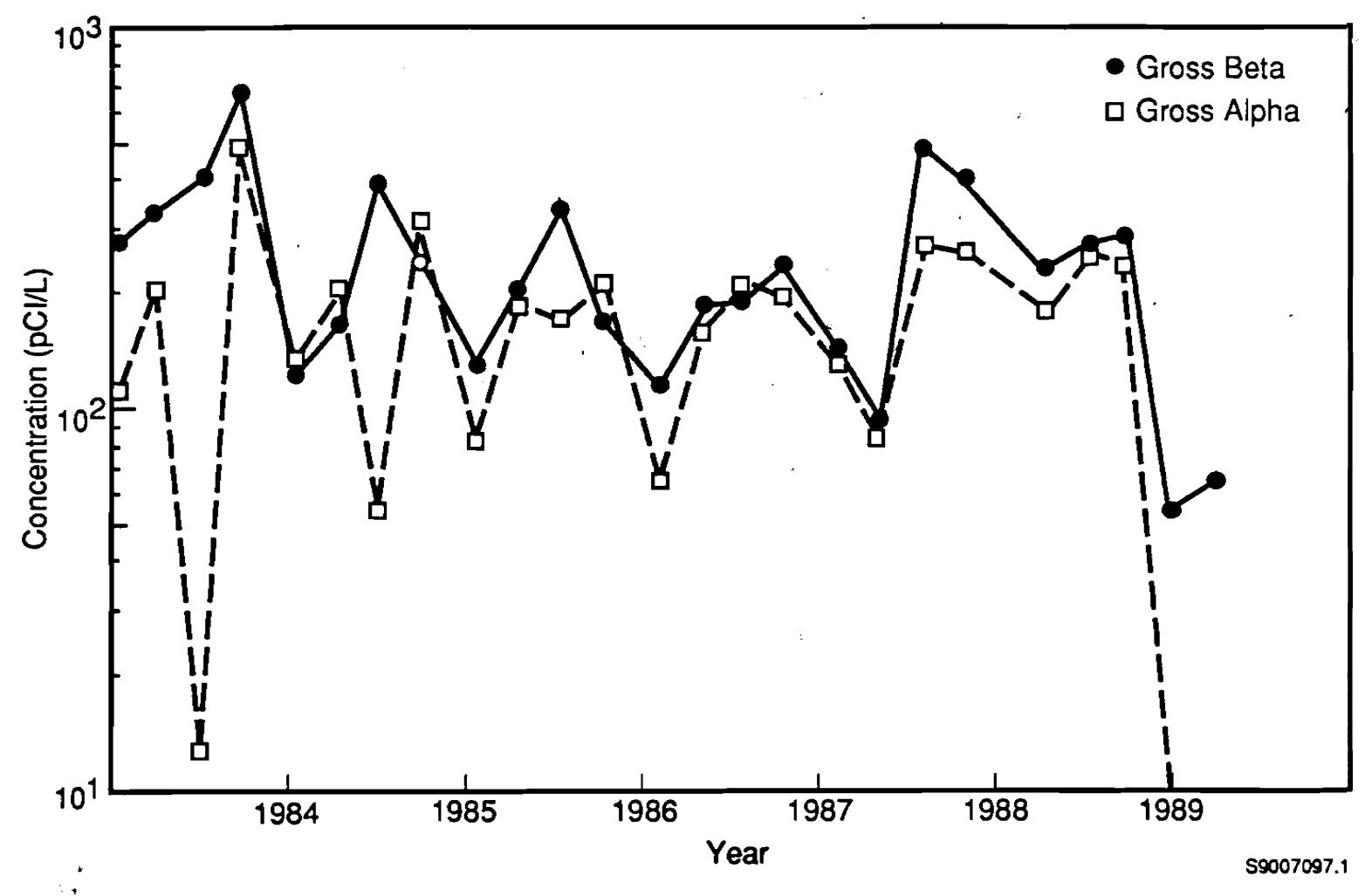

FIGURE C.5. Historical Levels of Gross Alpha and Gross Beta 

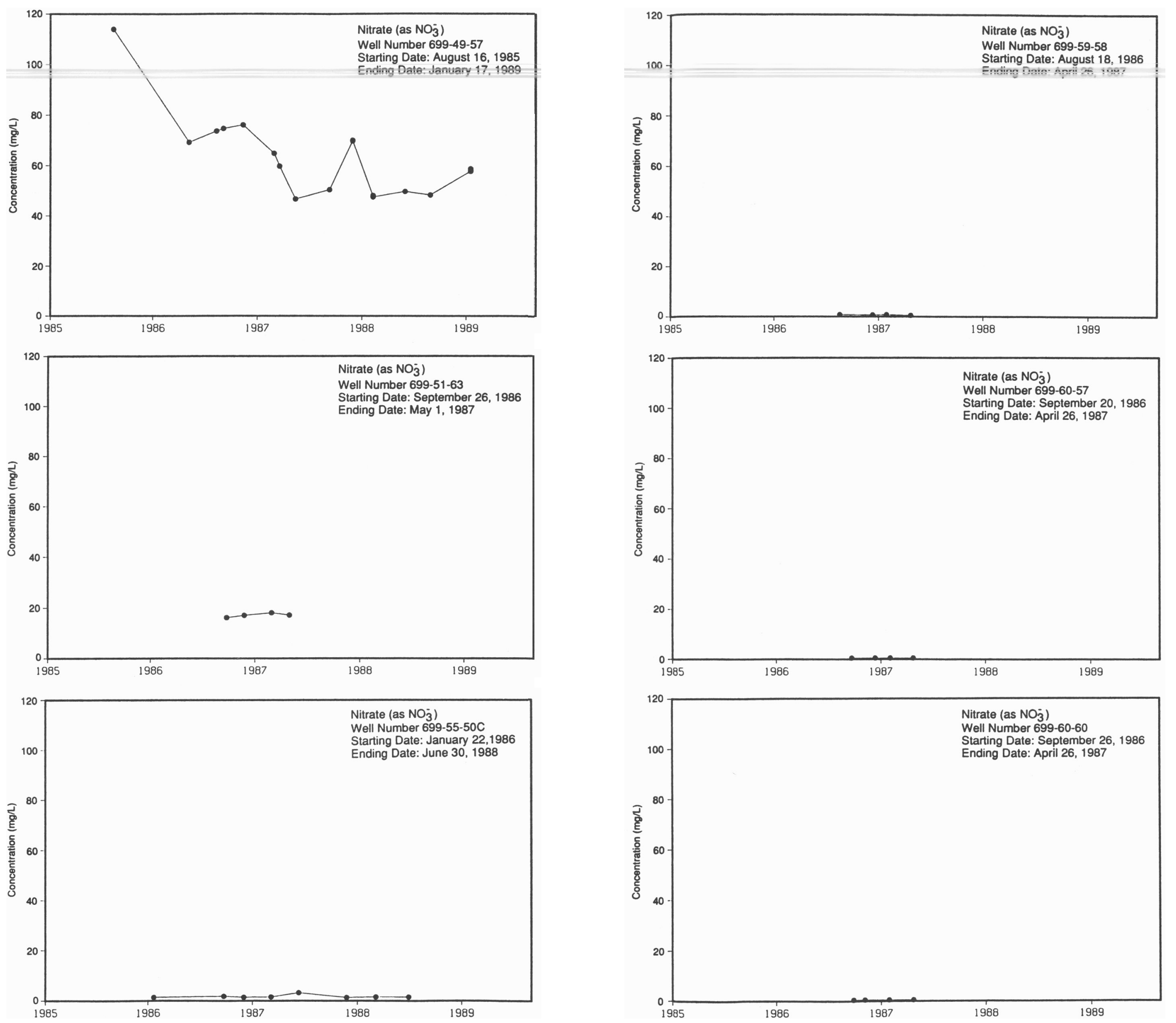

FIGURE C.6. Historical Levels of Nitrate (as $\mathrm{NO}_{3}^{-}$) on the Hanford Site in Selected Wells 


\section{DISTRIBUTION}

No. of

No. of

Copies

$\underline{\text { Copies }}$

\section{OFFSITE}

2 DOE/Office of Scientific and Technical Information

\section{ONSITE}

2 DOE Richland Operations Office

R. F. Brich

M. W. Tiernan

4 Westinghouse Hanford Company

L. P. Diediker

J. J. Dorian

K. A. Gano

- E. M. Greager

$48 \quad$ Pacific Northwest Laboratory
R. W. Bryce
L. L. Cadwe11
D. D. Dauble
R. L. Dirkes
P. G. Doctor

R. M. Ecker

J. W. Falco

M. D. Freshley

R. H. Gray

J. M. Hales

S. H. Hall

R. W. Hanf

P. C. Hays

W. R. James

R. E. Jaquish

B. V. Johnston

E. W. Lusty

D. L. Newcomer (5)

W. T. Pennell

T. M. Poston (5)

K. L. Price (5)

W. H. Rickard

R. G. Schreckhise

R. L. Skaggs

W. L. Templeton

B. L. Tiller

T. L. van Arsdale

H. E. Westerdahl

R. K. Woodruff (2)

Technical Report Files (5)

Publishing Coordination 